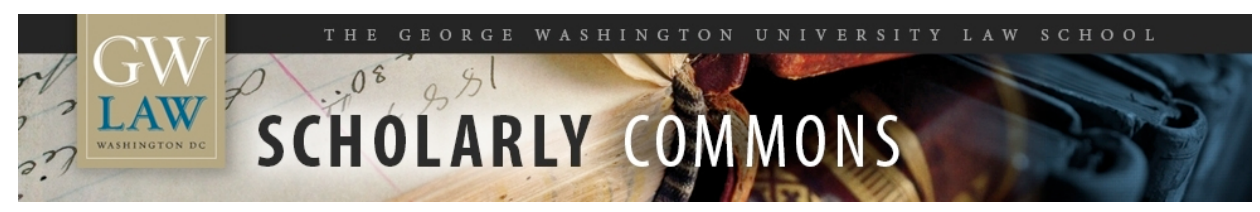

GW Law Faculty Publications \& Other Works

Faculty Scholarship

2001

\title{
Biotechnology and International Law
}

Sean D. Murphy

George Washington University Law School, smurphy@law.gwu.edu

Follow this and additional works at: https://scholarship.law.gwu.edu/faculty_publications

Part of the Law Commons

\section{Recommended Citation}

Sean D. Murphy, Biotechnology and International Law, 42 Harv. Int'l L.J. 47 (2001).

This Article is brought to you for free and open access by the Faculty Scholarship at Scholarly Commons. It has been accepted for inclusion in GW Law Faculty Publications \& Other Works by an authorized administrator of Scholarly Commons. For more information, please contact spagel@law.gwu.edu. 
Draft January 2001

\title{
Biotechnology and International Law
}

\author{
Sean D. Murphy*
}

I. INTRODUCTION

II. The Science of Biotechnology, Its Applications, And Its CRitics

The Science

The Applications

General Criticisms

III. Problems of Biotechnology in the Transnational Sphere

Equitable Concerns Regarding the Patenting of Genetically

Modified Organisms

Transparency Regarding Exports of Genetically Modified Products

Import Bans on Genetically Modified Products

Liability for Damage by Genetically Modified Imports

Liability for Extraterritorial Damage by Genetically Modified Products

Long-term Decline in Global Biological Diversity

IV. The JuRISGENERATIVE NATURE OF InTERnAtional LA W

International Law as Driven by the Self-Interest of Transnational Actors

International Law as Driven by Social Interaction Among

Transnational Actors

International Law as Grounded in National Law and Society

V. Tow ARd An EPISTEMIC COMmunity

Developing an Epistemic Community

The Structure of a Transnational Forum

The Goals of a Transnational Forum

Potential Crystallization of a Coherent Legal Regime

VI. CONCLUSION

*George Washington University Law School. My thanks to Patrick Abbot, John Knox, Michael Reisman, Sabrina Safrin, and the author's colleagues at the law school for their thoughtful comments on an earlier draft of this article, and to Dean Michael K. Young for financial support and Matthew Haws ('02) for outstanding research assistance. 


\section{INTRODUCTION}

If one were to forecast the areas involving the greatest technological breakthroughs for the new millennium, the genetic engineering made possible by biotechnology ${ }^{1}$ would be at or near the top of the list. It is entirely possible that over the next fifty years thousands of novel, genetically modified bacteria, viruses, plants and animals could be developed and released into the global environment for pharmaceutical, agricultural, medical, environmental remediation, alternative fuel, and other purposes. For some internationalists, this is extremely good news, especially for the developing world. For instance, recent estimates indicate that around 790 million people in developing states are chronically undernourished (meaning their food intake is insufficient to meet basic energy requirements on a continuing basis) and millions more experience under nutrition (meaning they lack essential vitamins and minerals in their diet) leaving them underweight and stunted. ${ }^{2}$ Absent biotechnology developments, one might doubt that current plant-breeding techniques could increase the world's food supply enough to

1 "Biotechnology" encompasses a variety of techniques, such as selecting natural strains of organisms that carry desirable traits, making hybrids by fusing cells from different parental sources, using chemicals and radiation to create mutant strains, or genetically engineering plants, animals, and micro-organisms to contain specific phenotypic characteristics. At its most general level, biotechnology concerns techniques for using the properties of living things to make products or services. The principal focus of this article is on recent, controversial developments in biotechnology relating to genetic engineering.

${ }^{2}$ U.N. Food and Agric. Org., The State of Food Insecurity in the World 1999 at 1011 (1999). 
feed an estimated 9.4 billion people by the year $2050 .^{3}$

Yet the dawn of the biotechnology world is generating serious transnational concerns that pose an enormous challenge for the international law and structures of our new century. Concerns arise over whether the genetic resources of the world, once manipulated, should be reducible to property rights, allowing a few companies of technologically-rich states to control access to food, medical, and other resources essential to the health and welfare of billions of people. Concerns arise over whether states should be notified first before any genetically modified products are exported to them, and once informed, on what grounds they may refuse to permit the export to occur. Already a trade impasse has developed between the United States and the European Union over genetically modified food, fueled by consumer demands for labeling schemes or even outright bans. To the extent that widespread bans on exports among developed states emerge, they may inhibit the ability of developing states to obtain the fruits of biotechnology for their own urgent needs, and close off markets for exports of genetically modified products from developing states to the developed world. Further concerns arise if genetic engineering causes transnational catastrophic harm. Although no such harm has occurred to date (such as by destabilizing a state's biosphere through "genetic pollution"), such an outcome is feared, and raises questions as to responsibility if such an event occurs. Finally, there are long-term concerns about the decline in global biological diversity, which may be accelerated by the widespread use of genetically modified products.

The purpose of this article, broadly stated, is to assess the strengths and limits of existing

${ }^{3}$ U.N. Population Fund, The State of World Population 1998 at 2-3, fig. 1 (1998). 
international law and structures designed to address these concerns, and to suggest a means for augmenting current structures to make them more effective. Part II begins with a discussion of the science of biotechnology, which is useful background for understanding its promises and perils, and then proceeds to briefly relate recent applications of the science and some general concerns about those applications. Part III clarifies and analyzes six specific concerns about biotechnology in the transnational sphere and associated international law and structures. As will be seen, there is no single treaty regime addressing these concerns but, rather, a segmented and at times conflicting network of intellectual property, trade, and environment treaties, accompanied by ambiguous customary law or principles. The few legal studies to date in this area tend to focus on just one of these several concerns, which results in an inability to see connections among them that suggest cross-sectoral opportunities for bargaining and cooperation among relevant state and non-state actors.

Prior scholarly studies in this area also tend to focus on state-to-state negotiations as the means for addressing transnational biotechnology. Yet, as discussed in Part IV, international law develops and regulates transnational behavior in a manner that goes well beyond the development treaty regimes. International law is driven in large part by the self-interest of states, but they also arise from the social interaction of states and non-state actors, and they ultimately must become grounded in national laws and society in order to become effective. While Part III emphasizes the need for coordination across different treaty regimes, Part IV emphasizes the need for coordination at different levels of state and non-state behavior as the law develops over time. While states should continue to grapple with concerns in the area of biotechnology through incremental tinkering of existing treaty regimes - seen most recently in the adoption of a Biosafety Protocol to the Convention on Biological Diversity - this 
article argues that the principal emphasis of the global community on episodic and segmented intergovernmental negotiations as a means for addressing these concerns is misplaced, especially since the science in this area is changing rapidly, the behavior to be regulated is highly commercial and private in nature, and transnational regulation affects a wide variety of state and non-state actors who have complex motivations that change over time.

Rather, as advanced in Part V, there is value in coordinating and augmenting traditional treaty regimes by the coalescence of an "epistemic community" of scientists, environmentalists, multinational businesses, trade organizations, development experts, academic groups, and others that transcend sectors. The many issues raised by biotechnology in the transnational sphere need to be addressed by international society as a whole, rather than left to the vagaries of the market, to governments alone, or to the initiatives of a few well-financed interest groups, such as biotechnology companies and environmentalists. One approach would be to establish a transnational forum on biotechnology, which could serve as a relatively informal and non-binding means for the transnational "bargaining" of views among a wide range of relevant non-state actors. Such a forum ultimately may be instrumental in achieving consensus on a coherent and effective legal regime to address concerns with transnational biotechnology, one that balances the tremendous opportunities of biotechnology against its potentially severe and adverse transnational effects.

Moreover, if successful, such a forum might provide a template for resolving the recurrent problem seen in reconciling other problems in the field of trade and environment, as well as clashes among other fields of international law. The structure of international society grows ever deeper in the ways in which non-governmental actors operate and cooperate across borders. Traditional methods of 
developing international law affecting private behavior must give way to newer approaches, ones that recognize the indispensability of cooperation among non-governmental actors in advance of the formation of new international legal regimes and in advance of major reforms of existing regimes. Otherwise, the development of international law in such areas will prove increasingly ineffective and unsatisfactory in responding to the demands of international society.

\section{The Science of Biotechnology, Its Applications, And Its CRitics}

\section{The Science ${ }^{4}$}

The term "biotechnology" can be applied to pre-twentieth century methods of producing dairy products, bread, or wine, as well as selective breeding of animals or cloning of plants by grafting. As such, the field has been around for centuries without creating any significant problems for national regulation, let alone international regulation. However, the genetic engineering of modern biotechnology — whereby a firefly can be crossed with a tobacco plant to produce a glowing

\footnotetext{
${ }^{4}$ The information contained in this section may be found in a variety of standard works on biotechnology. Non-scientists seeking more information may find accessible SuSAN ALDRIDGE, THE Thread of Life: The Story of Genes and Genetic Engineering (1996); Susan R. Barnum, Biotechnology: An Introduction (1998); Eric S. Grace, Biotechnology UnZipPed (1997); Biotechnology: Science, EngineERING, And ETHICAl CHALlEnges For the Twenty-First CENTURY (Frederick B. Rudolph \& Larry V. McIntire, eds. 1996). For standard scientific textbooks on genetics and biotechnology, see Bernard R. Glick \& Jack J. Pasternak, Molecular Biology (2d ed. 1998); Benjamin Lewin, Genes (6th ed. 1997); John E. Smith, Biotechnology (3d ed. 1996).
} 
plant - moves well beyond anything previously seen. Traditional cross-breeding involves selectively breeding for desired genetic traits, usually within a single species or species complex, while the genetic engineering that began in the 1970's allows genes to be transferred between distant species that would never interbreed in nature, raising new issues, questions, and problems in both the national and transnational sphere.

How is genetic engineering done? Each cell of an organism typically has a nucleus containing threadlike bodies known as chromosomes. Each chromosome contains tightly packed sequences of nucleotides, a compound consisting of a base, a phosphate group, and a sugar. These nucleotides arrange themselves structurally as two complementary chains wound in a helix, to form deoxyribonucleic acid (DNA). A sequence of nucleotides on a chromosome contains within it a particular piece of information about the organism's parent: that sequence is known as a gene. Different sequences of nucleotides provide codes for the creation of specific amino acids, which in turn dictate what cells are created. Why do the cells of a firefly egg develop so as to create a new firefly instead of, for example, a tobacco plant? The sequences of nucleotides in the chromosomes of the parent fireflies, when combined to create the off-spring firefly, dictate the arrangement of specific macromolecules, which results ultimately in the creation of a new firefly. ${ }^{5}$

By combining genes from the DNA of one species with that of another, is it possible to create a tobacco plant with leaves that glow like a firefly? There are various techniques for transferring genes; one of the first and still central techniques involves the use of bacteria and viruses. While the DNA of

\footnotetext{
${ }^{5}$ See generally GRACE, supra note 4, ch. 1.
} 
most cells is found on chromosomes located within a cell nucleus, bacteria do not have nuclei; their DNA is found on a single chromosome in the shape of a large, closed loop or a plasmid. These loops can pass readily from one cell to another. By contrast, a virus is simply a molecule of DNA (or its cousin, ribonucleic acid, or RNA) covered with a protective protein coat. Thus, while they have genetic instructions for making new versions of themselves, viruses do not have the biochemical capability to reproduce independently; they rely on other living organisms to do so. A virus can take over a bacterial cell by settling on the bacterium and injecting its nucleic acid into the cell (when it does this, it is known as a bacteriophage or phage). Once injected, the viral nuclear acid instructs the bacterial cell's biochemical machinery to produce more viral nucleic acid and protein coats, and then ruptures the cell membrane to allow the new viral particles to disperse. ${ }^{6}$

When attacked by a virus, however, bacteria will also counterattack by generating a group of enzymes, known as restriction endonucleases or restriction enzymes, that try to chop up the invading DNA. Different restriction enzymes recognize specific sequences of nucleotides and chop up the invading DNA at these points. Researchers have identified hundreds of restriction enzymes possessing unique recognition sites and therefore can use them as cutting tools. Because of the structure of DNA, any two fragments of DNA - from any biological source - cut by the same restriction enzyme can be joined together. ${ }^{7}$ So, if the relevant genes whose product emits light were chopped off from the DNA of a firefly and joined to relevant genes of a tobacco plant seed, the result would be a tobacco plant that

\footnotetext{
${ }^{6}$ See generally GRACE, supra note 4, ch. 1; see also SMITH, supra note 4, at 38-43.

${ }^{7} I d$.
} 
grows..$^{8}$

\section{The Applications}

Using such techniques, scientists are capable of joining DNA fragments from different sources to create novel DNA (known as recombinant DNA or rDNA) so as to take a valued quality of one organism and join it with the valued quality of a second organism. Although today's science is not advanced enough to know what fragments of DNA to combine in order to cross complex organisms without seriously disrupting the normal development of the embryo, ${ }^{9}$ there already exist many less complex applications of this new biotechnology.

In the medical field, scientists are developing plants genetically engineered to contain drugs that can then be extracted (or delivered by simply eating the plant), a process called molecular farming or "biopharming" that is far less costly process than current laboratory techniques. ${ }^{10}$ Scientists also envisage treating (and perhaps even curing) diseases through "gene therapy," by infusing a patient who

\footnotetext{
8 The feat was accomplished in 1986. See JEREMy RifKin, The Biotech CEntURy at 14 (1998).

${ }^{9}$ The control of genes in multi-celled organisms is highly complex. Scientists do not yet understand how undifferentiated cells within an embryo express different genes to produce different body tissues and organs. It is not enough to transfer genes that create the structure of an organ; one must also transfer the genes that regulate the sequence of events by which the structure is created. Modifications that have worked the best are the simplest, introducing just one or a few foreign genes into an organism.
}

${ }^{10}$ See Andrew Pollack, New Ventures Aim to Put Farms In Vanguard of Drug Production, N.Y. Times, May 14, 2000, at 1. 
has missing or defective genes with corrective doses of DNA. ${ }^{11}$ Genetic diseases such as cystic fibrosis ultimately may be cured through such applications, as well as more complex conditions involving the interactions of various genes that lead to heart disease, cancer, and Alzheimer's disease. Ultimately, gene therapy might result in longer living, more intelligent humans. ${ }^{12}$

To date, however, success with gene therapy has been minimal. ${ }^{13}$ Greater success exists in use of genetic engineering for the mass production of therapeutic proteins that would otherwise be difficult

${ }^{11}$ See generally Andrew Kimball, The Human Body Shop: The EngineERING AND Marketing of Life (1993); JefF Lyon \& Peter Gorner, Altered Fates: Gene Therapy and THE RETOOLING OF HuMAN LifE (1995). Scientists currently mapping the multi-billion-unit human DNA sequence hope that it will lead to an ability to identify and manipulate human genes responsible for aging and disorders, leading to treatments for cancer, heart disease, and other maladies. See Karl Lenhard Rudolph et al., Longevity, Stress Response, and Cancer in Aging Telomerase-Deficient Mice, 96 CELL 701 (1999). As of July 2000, two entities - a private company named Celera Genomics Corporation and a multi-national consortium of educational centers named the Human Genome Project-are on the verge of completing a total sequencing of genes of a human cell. See Rick Weiss \& Justin Gillis, DNA-Mapping Heralded, WASH. Post, June 27, 2000, at A1. As each gene sequence is uncovered by the Human Genome Project, there is complete and continuous public disclosure, which has the effect of blocking private patents on the uncovered gene sequence. For the consortium's Internet site, maintained by the U.S. National Center for Biotechnology, see $<$ http://www.ncbi.nlm.nih.gov/genome/seq>. Although public and private ventures are already seeking patents for various segments of the human genome, in all but a handful of these instances, the applicant does not yet understand the function, usefulness or commercial value of the genetic material.

${ }^{12}$ Scientists have already manipulated the DNA sequence of mouse genes so as to make a smarter mouse. See Ya-Ping Tang et al., Genetic Enhancement of Learning and Memory in Mice, 401 Nature 63 (Sept. 2, 1999).

${ }^{13}$ See, e.g., Sheryl Gay Stolberg, The Biotech Death of Jesse Gelsinger, N.Y. TIMES, Nov. 28, 1999, §6 (Magazine), at 136 (describing the unsuccessful seven-week University of Pennsylvania gene therapy experiment on a teenager suffering from a rare metabolic disorder); Philip J. Hilts, $A$ Second Death Linked to Gene Therapy, N.Y. TIMES, May 4, 2000, at A21; but see Marina Cavazzana-Calvo et al., Gene Therapy of Human Severe Combined Immunodeficiency (SCID)-X1 Disease, 288 Scr. 669 (2000) (describing an apparently successful gene therapy experiment on infants born with a life-threatening immune system disorder). 
or costly to produce, or even unavailable by conventional means. ${ }^{14}$ Animals are being engineered with special genetic traits from human genes, so that the animals can produce human proteins for making drugs to combat disease. ${ }^{15}$ In the future, engineered animals might even produce entire organs useable by humans by xenotransplants..$^{16}$ Moreover, once engineered, such animals can be duplicated $\mathrm{ad}$ infinitum through cloning (i.e., using a gene from an ancestor to produce a genetically identical organism).${ }^{17}$ Current U.S. policy, however, disfavors use of biotechnology to clone humans, largely out of ethical, moral, religious and legal concerns. ${ }^{18}$

${ }^{14}$ For instance, antibodies (proteins created by certain white blood cells to fight infection) have been very difficult to create in the laboratory using traditional methods, since white blood cells do not survive easily outside the body. Using techniques of biotechnology, however, the antibody-producing qualities of white blood cells have been fused with cancer cells, which have the property of unstoppable growth, so as to turn out a continuous supply of antibodies. Other therapeutic proteins replicated using genetic manipulation include insulin, alpha interferon, and human growth hormones, some of which have purely animal applications. One advantage of using human genes to produce the drugs for humans is that they are less likely to generate adverse side-effects.

${ }^{15}$ See Justin Gillis, Down on the High-Tech Pharm, WAsh. Post, Jan. 17, 2000, at A1; Justin Gillis, Cows and Clones on a Va. Pharm, WASH. Post, Feb. 28, 1999, at A1.

${ }^{16}$ See, e.g., Sheryl Gay Stolberg, Could This Pig Save Your Life? N.Y. Times, Oct. 3, 1999, §6 (Magazine), at 46 (describing efforts to insert human genes into pig embryos, so that the organs of the grown pig, when transplanted into the physiologically similar humans, will not be rejected by the human immune system); Andrew Kimbrell, The Human Body Shop: The Engineering AND MARKETING OF LIFE (1993).

${ }^{17}$ In 1996, Scottish scientists successfully cloned a lamb from an adult sheep, by taking the nucleus of an adult sheep's cell and transferring it into another sheep's unfertilized egg. The "reconstructed" embryo was placed in the womb of a foster mother and brought to term. Thus, was born Dolly. See I. Wilmut et al., Viable Offspring Derived from Fetal and Adult Mammalian Cells, 385 NATURE 810 (1997).

${ }^{18}$ See Remarks Announcing the Prohibition on Federal Funding for Cloning of Human Beings and an Exchange with Reporters, Mar. 4, 1997, 1997 Pub. PApers: William J. Clinton 230-32 (President Clinton urging "the entire scientific and medical community, every foundation, every 
The transnational implications of these biotechnology applications are significant; if made widely available, such pharmaceuticals and medical treatments can potentially improve the health and wellbeing of millions of people worldwide afflicted with treatable diseases and conditions. Moreover, certain applications could be targeted to the needs of the developing world. For instance, scientists may be within striking distance of plants that would produce edible vaccines and insulin, a highly practical means of distribution to developing states that would obviate the cost of transportation, the need for refrigeration, and the dangers of using needles. ${ }^{19}$ Separately, scientists are trying to reengineer insects so that they cannot spread major diseases, such as malaria, yellow fever, trypanosomiasis and dengue, which afflict millions of people each year, particularly in developing states. Insects harmful to the agricultural economies of Argentina, Chile, Guatemala, Japan, Mexico, Tanzania, and the United States are already breed in captivity to be sterile, so that when released they diminish the overall population;

university, every industry that supports work in this area to heed the Federal Government's example" and to undertake a voluntary moratorium on the cloning of human beings "until our Bioethics Advisory Commission and our entire Nation have had a real chance to understand and debate the profound ethical implications of the latest advances"). The National Bioethics Advisory Commission was established by Exec. Order No. 12,975, 3 C.F.R. 409 (1995), reprinted in 42 U.S.C. $\$ 6601$ (Supp. II 1996).

In January 1998, the FDA asserted that it had January 1998 that it had statutory authority to regulate human cloning. See Gregory J. Rokosz, Human Cloning: Is the Reach of FDA Authority Too Far a Stretch? 30 Seton Hall L. Rev. 464 (2000). Meanwhile, some U.S. states have banned human cloning. See, e.g., CA L. Health \& SAFety Code $\$ 24185$ (West Supp. 2000).

On ethical, social, religious, and legal concerns regarding cloning of humans, see generally THE Genetic Revolution and Human Rights (Justine Barley ed., 1999); Na T'L Bioethics Advisory Commission, Cloning Human Beings:Report and Recommendations of the National BIOETHICS ADVISORY COMMISSION (1997) (concluding that the inefficiency and risk of known cloning techniques made research on human cloning inappropriate); DANIEL J. KEEVLES \& LeROY HoOD, THE Code of Codes: Scientific and Social Issues in the Human Genome Project (1992).

${ }^{19}$ See Anne Simon Moffat, Toting Up the Early Harvest of Transgenic Plants, 282 ScI. 2176 (1998). 
with biotechnology this process may become simpler and more effective..$^{20}$

Next to applications of biotechnology in the medical field rank those in the field of agriculture. ${ }^{21}$

Genetically modified microorganisms might be developed that, when released into the environment, may help control soil acidity/alkalinity or salinity, thereby increasing the geographic range of crops. Already, "transgenic crops" can be genetically modified to do better at surviving drought or frost, ${ }^{22}$ to stay

${ }^{20}$ See David A. O’Brochta \& Peter W. Atkinson, Building the Better Bug, ScI. Am., Dec. 1998 , at 90 .

${ }^{21}$ See generally Maurizio G. Paoletti \& David Pimentel, Genetic Engineering in Agriculture and the Environment, 46 BIOSCIENCE 665 (1996). For an analysis of ethical and social issues that reaches conclusions favorable to continued development of biotechnology, see NUFFIELD COUNCIL ON Bioethics, Genetically Modified Crops: The Ethical and Social Issues (1999), $<$ http://www.nuffieldfoundation.org $>$.

22 The first genetically engineered micro-organism for use in agriculture authorized by the U.S. Government to be field-tested concerned a frost-inhibiting bacteria, known as "ice minus." Ice minus was developed by taking bacteria that promoted ice formation (formally called pseudomonas syringae), isolating the ice-promoting protein within it and, through use of recombinant DNA techniques and restriction enzymes, creating a new bacterium lacking in the protein (other methods of creating the mutant strain were also used). Once sprayed on crops, it was hoped that the engineered strain of bacteria would delay frost formation at least until the temperature dropped below $-10 \mathrm{~B} C$. The field tests on ice minus that began in 1987, however, ultimately revealed that some naturally occurring strains of pseudomonas syringae were just as effective as ice minus, leading to the abandonment of further research, testing and development of ice minus. See SHELdON KRIMSKY \& Roger P. WrUbel, Agricultural Biotechnology AND the EnVironment 154-65 (1996). 
fresher longer, ${ }^{23}$ to resist insect pests and diseases (viruses), ${ }^{24}$ and to tolerate herbicides, which allow farmers to spray weedkiller on fields without damaging crops. ${ }^{25}$ The same biotechnology tools can be applied to livestock, so as to improve the quality and quantity of milk, eggs, meat, and wool, and to produce healthier, faster-growing animals. ${ }^{26}$

${ }^{23}$ The first genetically modified product for food use to receive U.S. Government approval was the Flavr-Savr tomato, developed by Calgene. Approved in May 1994, the tomato had been genetically engineered so that it could stay on the vine until fully ripe, picked, but then delay ripening (and hence rotting) further. See Calgene, Inc., Availability of Letter Concluding Consultation, 59 Fed. Reg. 26,647 (Dep't Health \& Human Services 1994). The Flavr-Savr tomato proved less successful than hoped, as it cost more and did not taste as good as competing tomatoes.

${ }^{24}$ The first genetically modified, insect-resistant crop to receive U.S. Government approval for commercial sale was the Monsanto's NewLeaf potato. Approved in 1995, the genetic structure of the potato was modified to contain genes from a natural soil bacterium (Bacillus thuringiensis, or Bt) which emits organic toxins that, when ingested, kill certain insects. The same bacterium, however, is quickly broken down into harmless chemicals when ingested by humans due to the highly acidic conditions of human stomachs. Ironically, Bt is the principle insect-controlling spray used by organic farmers, since it is an organic insecticide. Many genetically modified, insect-resistant crops currently used contain the Bt gene. See Michael Pollan, Playing God in the Garden, N.Y. Times, Oct. 25, 1998, §6 (Magazine), at 44 .

25 The first herbicide-tolerant transgenic plant approved for commercial use was a type of cotton that could tolerate the herbicide bromoxynil. One of the most extensively used herbicidetolerant, genetically modified crops in the United States are Monsanto's "Roundup Ready" canola, corn, cotton, and soybeans. "Roundup" is a Monsanto herbicide that has been used commercially for more than twenty years. It contains glyphosate, which kills weeds by interfering with an enzyme in their growth mechanism (a mechanism not found in animals). Through biotechnology, tolerance to "Roundup" has been transferred to desirable crops, allowing farmers to spray fields with "Roundup" to eliminate weeds without harming their crops. See Rick Weiss, Seeds of Discord, WASH. Post, Feb. 3, 1999, at A1. Monsanto argues that farmers can spray "Roundup Ready" crops less often than normal crops. See Monsanto Press Release on Environmental Benefits Of Crops Developed Through Biotechnology (July, 1997), <http://www.monsanto.com/monsanto/mediacenter./background/97jul_EnvBenefits.html>.

${ }^{26}$ For example, in February 1994, the U.S. Food and Drug Administration approved for use in the United States a bovine growth hormone to increase a cow's milk yield by up to twenty percent. The hormone, known as bovine somatotropin (BST), occurs naturally in cows, but can also be produced 
All told, the U.S. Department of Agriculture (USDA) has approved some 50 varieties of genetically modified crops. In 2000 in the United States, 52 percent of approximately 75 million acres of soybeans, 56 percent of approximately 15.5 million acres of cotton, and 25 percent of approximately 78 million acres of corn are planted with genetically modified crops ${ }^{27}$ Those crops are used to produce a wide range of products consumed worldwide. For example, soy is present in an estimated 60 percent of all processed foods (mostly in the form of flour, oil and lecithin), including breads, baby foods, salad dressings, and ice cream. ${ }^{28}$

Again, the transnational implications of these agricultural biotechnology applications are significant; they can help farmers worldwide minimize the enormous amounts of chemical fertilizer, pesticide, water, machinery and fuel necessary to produce food. Food can be produced at lower costs and with less use of chemicals considered harmful to human health and the environment. ${ }^{29}$ That

cheaply by inserting genes associated with the pituitary gland of cattle into bacteria, which then manufacture the hormone. Once produced, the hormone can be either injected in the cow or added to the cow's feedstock. See KRIMSKY \& WRUBEL, supra note 22, at 167-90; SMITH, supra note 4, at 175-76.

${ }^{27}$ See National Agric. Statistics Serv., U.S. Dep't of Agric., Prospective Plantings 4, 12, 18, 23-24 (2000), <http://jan.mannlib.cornell.edu/reports/nassr/field/pcp-bbp>. Most of the transgenic plants currently being developed in the United States are to tolerate chemical herbicides or weedkillers. See Jane Rissler and Margaret Mellon, The Ecological Risks of EngineERed CROPS 14-15 (1996).

${ }^{28}$ See Seeds of Change, Consumer REP., Sept. 1999, at 41.

${ }^{29}$ See Robert B. Horsch, Biotechnology and Sustainable Development, in BioteCHnOLOGY AND BIOSAFETy 25 (Ismail Serageldin \& Wanda Collins eds., 1999). A study by the U.S. Department of Agriculture found that the farm-level impacts of genetically crops on pesticide use, yields, and net returns vary with the crop and technology examined. For instance, adoption of herbicide-tolerant cotton led to significant increases in yields and net returns, but was not associated with significant changes in herbicide use, while increases in adoption of herbicide-tolerant soybeans led to small but significant 
possibility is of particular interest to the lesser developed states: China and India, for example, can only feed their growing populations through continuous improvements in crop yields. ${ }^{30}$ By using crops genetically modified to have beneficial characteristics, developing states may find that they can meet increasing demand, while practicing even more environmentally benign agricultural methods. Not only might the supply be increased, but foods could be engineered to have a higher nutritive value, possessing more vitamins, healthy fats and oils, or could be engineered to stay fresh longer in tropical states. $^{31}$

Although there are concerns about the adverse environmental effects of manipulating nature

increases in yields, no changes in net returns, but significant decreases in herbicide use. See JorGE Fernandez-Cornejo \& William D. McBride, U.S. Dep't of Agric., Agric. Econ. Rep. No. 786, Genetically Engineered Crops for Pest Management in U.S. Agriculture (2000), $<$ http://www.ers.usda.gov/epubs/pdf/aer786/>.

${ }^{30}$ See Anne Kathrine Hvoslef-Eide \& Odd Arne Rognli, Environmental Issues for Plant Biotechnology Transfer: A Norwegian Perspective, in Plant Biotechnology Transfer to Developing Countries 37, 38-39 (David W. Altman \& Kazuo N. Watanabe eds., 1995) (arguing that biotechnology "will probably provide the key for producing more food and other agricultural commodities from less land and water in the twenty-first century, without the adverse ecological implications associated with the expression of the full yield potential of high-yielding crop varieties through high-input agriculture").

${ }^{31}$ See generally Agricultural Biotechnology in InTERnational Development (Catherine L. Ives \& Bruce M. Bedford eds., 1998). For example, scientists have now created a strain of genetically altered rice carrying beta-carotene, a compound that is converted into vitamin A within the human body. Vitamin A deficiency is the world's leading cause of blindness, creates susceptibility to a host of diseases, and is the source of a malaise that affects as many as 250 million children. Millions of those suffering the deficiency cannot be reached through distribution of pills, leaving genetically modified crops a low-cost yet effective option. See Xudong Ye et al., Engineering the Provitamin A ( $\beta$ Carotene) Biosynthetic Pathway into (Carotenoid-Free) Rice Endosperm, 287 Scr. 303 (2000). It is estimated that every year some 500,000 children become blind or partially blind from vitamin A deficiency. See Transgenic Plants and World Agriculture 10 (July 2000), $<$ http://bob.nap.edu/html/transgenic $>$ (collaborative report of eight national academies of science, including the U.S. National Academy of Sciences). 
through biotechnology, it is important to note that there are several potentially positive uses of biotechnology, such as through genetically engineering crops to require less inputs (land, water, pesticides). One potential benefit relates to environmental clean-up. For decades tiny bacteria (or microbes) have been used to treat domestic sewage, industrial waste water, or other environmental pollutants, by essentially feeding upon large, complex, harmful molecules, and thereby breaking them down into smaller, harmless ones. After the 1990 oil spill by the Exxon Valdez off the coast of Alaska, Exxon used microbe-enhanced fertilizers to help clean beaches and shorelines of the oil debris. ${ }^{32}$ This process, referred to as bio-remediation, has one principle drawback: unpredictability. At any given waste site, various factors (such as climate and soil) can effect the speed and effectiveness of the bioremediation. For that reason, scientists are currently studying how such bacteria can be genetically engineered for greater reliability and to expand the number of pollutants that can be treated. ${ }^{33}$

\section{General Criticisms}

With the advent of genetic engineering has come a host of concerns both nationally and transnationally. While U.S. biotechnology companies, their trade associations, U.S. government officials, and others interested in using biotechnology (such as farmers, doctors, and industrial waste managers) assert that current U.S. regulation is sufficient to protect human health and the environment, many U.S. consumer and environmental groups believe that genetically modified products are inherently

\footnotetext{
${ }^{32}$ See Janet Raloff, An Alaskan Feast for Oil-Eating Microbes, 143 ScI. News 253 (1993).

${ }^{33}$ See GRACE, supra note 4, at 138-39; see also SMITH, supra note 4, at 154-55.
} 
dangerous and should not be developed further absent extensive long-term testing, if at all. In particular, critics note that unlike hazardous chemicals or wastes, genetically modified organisms are potential hazards "with legs," capable not just of spreading but of proliferating. ${ }^{34}$ Reviewing the scientific literature shows that scientists can be found to support both positions, with molecular biologists tending to see little risk in genetically modified organisms, and ecologists tending to see more. The widespread introduction in the United States of bioengineered products, from food to fabric, initially provoked little reaction from the public at large, but that now may be changing, and may result in greater attention by politicians to the means by which biotechnology is regulated.

Fears have arisen over various potential aspects of the new biotechnology: unknown toxins, antibiotic resistance, religious infringements, allergic reactions, counterfeit freshness, "genetic pollution," and other adverse effects from the introduction of exotic organisms into ecosystems. For instance, with respect to medical applications of biotechnology, critics note that xenotransplants may allow for a plentiful supply of engineered organs for thousands of needy human recipients, but they also may create the potential for the contamination of humans with viruses or retroviruses (viruses that integrate their genetic code into the cells they infect). ${ }^{35}$ With respect to the agricultural field, critics detected in taco

${ }^{34}$ See generally M. ChiARA MAnTEgazzini, The EnVIRONMENTAL Risks From BIOTECHNOLOGY (1986); RIFKIN, supra note 8; V.E.A. Russo, GENETIC ENGINEERING: DREAMS AND NightMARES (1995).

${ }^{35}$ Some critics fear that the genetically modified pig organ transplanted into a human could carry with it the porcine endogenous retrovirus (PERV). See, e.g., Stolberg, supra note 16, at 49. As for the consequences of infecting humans with such retroviruses, most AIDS researchers now believe that the HIV retroviruses are really primate viruses that somehow jumped into humans, with one theory focusing on polio vaccines grown from monkey kidneys that were fed to Africans in Burundi, the Congo, and Rwanda in 1957-60. See Edw ARd Hooper, The River: A Journey to the Source of HIV AND AIDS (1999); Helen Epstein, Something Happened, N.Y. REV. BooKs, Dec. 2, 1999, at 
shells sold in grocery stores a form of genetically modified corn approved as an animal feed, but not for human consumption because of allergy concerns, prompting a voluntary recall by a major U.S. food company. ${ }^{36}$

Critics of bio-engineering argue that genetically modified products destined for human or animal consumption are inadequately regulated by national authorities,${ }^{37}$ including the U.S. Government. ${ }^{38}$ In the United States, there is no comprehensive statute addressing the testing and monitoring of genetically

14. On the likely acquisition by humans throughout history of viruses from domesticated animals, see Jared M. Diamond, Guns, Germs \& Steel: The Fates of Human Societies 196-97, 207-09 (1997).

${ }^{36}$ See Marc Kaufman, Biotech Critics Cite Unapproved Corn in Taco Shells, WASH. Post, Sept. 18, 2000, at A2; Marc Kaufman, Biotech Corn Fuels A Recall, WAsH. Post, Sept. 23, at A1. Genetic engineering in the pharmaceutical context has raised fewer concerns, largely because it is often amenable to chemical synthesis, so that commercial production need not involve the original biological source material. See Organization FOR ECON. COOPERATION AND DEV., INTELLECTUAL PROPERTy, Technology Transfer and Genetic Resources 28-29 (1996) [hereinafter OECD RePORT].

${ }^{37}$ For an analysis of regulations in various states relevant to emergent biotechnology applications, see OECD, Compendium of National Food Safety Systems and Activities, OECD Doc. SG/ADHOC/FS(2000)5/ANN/FINAL (June 8, 2000); Judy J. Kim, Out of the Lab and Into the Field: Harmonization of Deliberate Regulations of Genetically Modified Organisms, 16 FORDHAM INT'L L.J. 1160 (1992-93).

${ }^{38}$ For criticisms of U.S. regulation, see generally Mary Jane Angelo, Genetically Engineered Plant Pesticides: Recent Developments in the EPA's Regulation of Biotechnology, 7 U. FLA. J.L. \& Pub. PoL'y 257 (1996); David J. Earp, The Regulation of Genetically Engineered Plants: Is Peter Rabbit Safe in Mr. McGregor's Transgenic Vegetable Patch? 24 EnVTL. L. 1633 (1994); Diane E. Hoffmann, The Biotechnology Revolution and its Regulatory Evolution, 38 DRAKE L. REV. 471 (1988-89). For an early suit against the U.S. Government by environmental groups, see Foundation on Economic Trends v. Heckler, 756 F.2d 143 (D.C. Cir. 1985) (forcing the U.S. government to engage in greater environmental assessment of release of genetically modified organisms). Part of the problem is that the lines drawn between the mandates of regulatory agencies are blurred when faced with genetic engineering; is a potato engineered to kill pests that seek to eat it to be regulated as a food or a pesticide? See Pollan, supra note 24, at 50. 
altered products; indeed, such products have never been tested for long-term effects on human health.

Rather, genetically altered products are regulated under existing statutes relating to food, drugs, agriculture, or the environment principally ${ }^{39}$ by the Food and Drug Administration (FDA), ${ }^{40}$ the USDA,${ }^{41}$ and the Environmental Protection Agency (EPA). ${ }^{42}$ Although as yet there is no scientific

${ }^{39}$ Other federal entities, such as the National Institutes of Health, the National Science Foundation, and the Department of Energy also play a role in federal regulation of the biotechnology industry. In fact, the earliest U.S. regulations concerning biotechnology arose with NIH's effort to address contained testing in laboratories and greenhouses that developed during the 1970s. See Guidelines for Research Involving Recombinant DNA Molecules, 45 Fed. Reg. 77,384 (1980). For the White House's interagency coordinating guidelines, see Coordinated Framework for Regulation of Biotechnology, 51 Fed. Reg. 23,302 (1986). Those guidelines make clear that existing laws will regulate biotechnology, that the products of biotechnology (rather than the process) will be regulated, and that the safety of a biotechnology product will be decided on a case-by-case basis.

40 The FDA regulates biotechnology products under statutes relating to food (except for meat, poultry, and egg products), feed, drugs, and medical devices. See Federal Food, Drug and Cosmetic Act (FFDCA), 21 U.S.C. $\S 301-95$ (1994); 21 C.F.R. $§ 171.1-571.1$ (2000). In May 1992, the FDA published a policy statement regarding food derived from new plant varieties. In it, the FDA concluded that food and feed derived from genetically modified organisms should be regulated in the same manner as food and feed derived from traditionally bred plants, which leaves with the producer the responsibility to assure the safety of the food. See Statement of Policy: Foods Derived from New Plant Varieties, 57 Fed. Reg. 22,984 (1992). For the FDA's Internet site on biotechnology, see $<$ http://vm.cfsan.fda.gov/ /rd/biopolcy.html>. Ensuring that the commercial supply of meat, poultry, and egg products is safe and correctly labeled and packaged is not regulated by the FDA but, rather, by the USDA.

${ }^{41}$ The USDA considers biotechnology applications as part of its mandate for ensuring the purity, potency, efficiency, and safety of agricultural products. Relevant statutes include the VirusSerum-Toxin Act, 21 U.S.C. $§ \S 151-59$ (1994), the Federal Meat Inspection Act, 21 U.S.C. $\$ 606$ (1994), the Poultry Products Inspection Act, 21 U.S.C. $\$ \$ 451-70$ (1994), the Plant Quarantine Act, 7

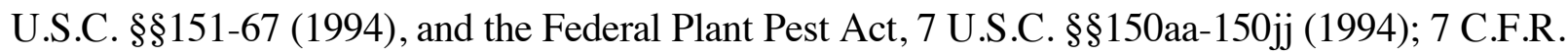
$\S \$ 340.0-340.9$ (2000); 9 C.F.R. $\$ \$ 309.17 \& 381.75$ (2000). For the USDA's Internet site on biotechnology, see <http://www.aphis.usda.gov/biotech>.

42 The EPA regulates genetically modified organisms primarily under statutes relating to toxics and pesticides. See Toxic Substances Control Act (TSCA), 15 U.S.C. §§2601-2629 (1994) (regulating toxic substances); Federal Insecticide, Fungicide and Rodenticide Act (FIFRA), 7 U.S.C. 
evidence of any harm to humans from eating genetically modified food ${ }^{43}$ critics charge that more extensive studies should be conducted by independent scientists regarding the risks to human and animal health from consumption of genetically modified food.

Further, critics worry about the environmental effects of genetically modified crops ${ }^{44}$ Critics doubt industry claims that use of genetically modified crops will decrease the use of conventional pesticides, since crops engineered to be resistant to herbicides arguably will result in far greater use of herbicides by farmers (since there is no concern with hurting the crop itself). Moreover, critics fear that

$\S \$ 136-136 y$ (1994) (regulating pesticides). The EPA also has responsibilities under the FFDCA, 21 U.S.C. $\S 346 a(a)-(0)$ (1994) (regulating tolerances or exemptions for the requirement of a tolerance for pesticide residues in foods). Relevant regulations may be found at C.F.R. $\$ \$ 152.1-152.500$, 172.1-172.59, 180.1-180.1206, \& 725.1-725.1000 (2000). For the EPA's Internet sites on biotechnology, see <http://www.epa.gov/opptintr/biotech/index.html > (for bio-toxics); $<$ http://www.epa.gov/pesticides/activity.htm\#bio $>$ (for bio-pesticides)

${ }^{43}$ See Committee on Genetically Modified Pest-Protected Plants, National Research Council, Genetically Modified Pest-Protected Plants: Science and REGULATION (2000), <http://books.nap.edu/catalog/9795.html>. One controversial study, however, has found that rats fed with genetically modified potatoes experienced a thickening of their intestines. See Stanley W.B. Ewen \& Arpad Pusztai, Effect of Diets Containing Genetically Modified Potatoes Expressing Galanthus Nivalis Lectin on rat Small Intestine, 354 LANCET 1353 (1999). Various scientists charged that this study was severely flawed. See Richard Horton, Genetically Modified Foods: "Absurd” Concern or Welcome Dialogue? 354 LANCET 1314 (1999); Rick Weiss, Gene-Altered Food Study Fuels a Fire, WAsH. Post, Oct. 15, 1999, at A3.

${ }^{44}$ See generally Miguel A. Altieri, The Environmental Risks of Transgenic Crops: An Agroecological Assessment, in Biotechnology And Biosafety, supra note 29, at 31; Rebecca J. Goldburg, Environmental Concerns with the Development of Herbicide-Tolerant Plants, 6 WEED Technology 647 (1992); James Kling, Could Transgenic Supercrops One Day Breed Superweeds? 274 SCI. 180 (1996); RISSLER \& MELLON, supra note 27. The critics, of course, have their detractors. See, e.g., Bryce W. Falk \& George Bruening, Will Transgenic Crops Generate New Viruses and New Diseases? 263 SCI. 1395 (1994) (doubting that genetic engineering creates a greater risk of new viruses than exists naturally). For a review of the debate, see H.J. Rogers \& H.C. Parkes, Transgenic Plants and the Environment, 46 J. EXPERIMENTAL BotAny 467 (1995). 
transgenic plants will alter the balance of an eco-system in ways that cannot be predicted and, in the long-term, can be very harmful to the environment. For instance, genetic engineering might inadvertently generate new, more virulent strains of virus or pathogenic bacteria harmful to the environment or, at a minimum, might threaten genetic diversity by promoting uniform crop systems. Herbicide-resistant traits of a transgenic plant could transfer by pollination to weeds, creating uncontrollable "superweeds." 4 Increased use of insecticides made possible by insecticide-resistant plants could lead insects to mutate into insecticide-resistant "superbugs." Further, by genetically manipulating crops so as to poison insects, it may be inevitable that harmless insects or beneficial insects (i.e., insects that feed on pests) are poisoned, thus actually increasing the pest population and decreasing biological diversity among insects. ${ }^{46}$ For that reason, the U.S. Government encourages (but does not legally require) growers of most genetically modified crops to maintain a certain amount of acreage planted with non-genetically modified crops, for the purpose of allowing some non-mutated insects to survive and, by breeding with any mutating insects, decrease the likelihood (or at least the speed) of mutation. ${ }^{47}$

${ }^{45}$ For a recent example, see Carol Kaesuk Yoon, Squash With Altered Genes Raises Fears of "Superweeds," N.Y. TIMES, Nov. 3, 1999, at A1.

46 See, e.g., Allison A. Snow \& Pedro Morán Palma, Commercialization of Transgenic Plants: Potential Ecological Risks, 47 BIoSCIENCE 86, 93 (1997).

${ }^{47}$ See Rick Weiss, Corn Seed Producers Move to Avert Pesticide Resistance, WASH. Post, Jan. 9, 1999, at A4. Even though the soil bacterium Bt is already used to spray crops, see supra note 24 , critics charge that crops genetically modified to contain Bt add much more of the toxin to the environment and are less apt to degrade, thus threatening insects far more with extinction, and in turn prompting greater mutation. 


\section{Problems of Biotechnology In the TRANSNATional SpHere}

The advent of modern biotechnology is already generating various concerns in the transnational sphere which the global community is struggling to address through disparate and largely uncoordinated treaty regimes. ${ }^{48}$ Although some success has been achieved, the rapid development of biotechnology applications will place increasing stress on traditional regulatory regimes. For instance, as xenotransplants become more common, national regulations may be developed in some states to prevent animal viruses from jumping into humans, but what if comparable regulations do not exist in other states, leading to the risk of such viruses originating elsewhere and then traveling to the highly regulated states? Even if cloning of humans is banned by some states, how should international law - including human rights law - handle humans that are cloned or hybrid mammals (part human, part non-human) created in other states $?^{49}$ Suppose the United States genetically engineers a microbe

${ }^{48}$ For Internet sites dealing with biotechnology in the transnational sphere, see listings that appear at the Internet site operated jointly by the Organization for Economic Cooperation and Development (OECD) and the U.N. Industrial Development Organization (UNIDO), <http://www.oecd.org/ehs/biobin>. The U.S. Information Agency also maintains an Internet site on global biotechnology issues at <http://usinfo.state.gov/topical/global/biotech>.

${ }^{49}$ See Rochelle Cooper Dreyfuss \& Dorothy Nelkin, The Jurisprudence of Genetics, 45 VAND. L. ReV. 313 (1992); Stevan M. Pepa, International Trade and Emerging Genetic Regulatory Regimes, 29 LAw \& POL'Y INT'L Bus. 415, 443-46 (1998) (suggesting that a hybrid creature could be regarded as a person with full legal rights, as a patented life form owned by its creator, or something in between). Some relevant rules of international law already exist, such as those prohibiting slavery, but the central question is how the international community defines a "person."

As a first step toward addressing ethically questionable applications of biotechnology in the field of medicine, twenty-three European states have signed the Convention for the Protection of Human Rights and Dignity of the Human Being With Regard to the Application of Biology and Medicine: Convention on Human Rights and Biomedicine, done Apr. 4, 1997, Eur. T.S. 164, reprinted in 36 I.L.M. 817 (1997), which addresses issues such as gene therapy, genetic discrimination, and organ or 
capable of destroying all coca plants in Columbia as a means of eliminating drug trafficking; is it for those governments alone to decide on its deployment, or do other groups or governments have a legal entitlement to speak to the issue ${ }^{50}$ Indeed, if biotechnology succeeds in generating new, revolutionary capabilities, the global community will have to confront the degree of transnational cooperation that is desirable (whether for economic, political or moral reasons) either to regulate those capabilities or to help finance those capabilities so as to make them available to those in need. ${ }^{51}$

Concerns with potential biotechnology applications in the transnational sphere are too numerous to address fully within the scope of this article. Consequently, this section focuses on concerns that have

tissue transplantation. See also Additional Protocol to the Convention for the Protection of Human Rights and Dignity of the Human Being With Regard to the Application of Biology and Medicine, on the Prohibition of Cloning Human Beings, Jan. 12, 1998, Eur. T.S. No. 168, reprinted in 36 I.L.M. 1415 (1997).

The U.N. Educational, Scientific, and Cultural Organization (UNESCO) has adopted a nonlegally binding declaration stating that human cloning is "contrary to human dignity" and "shall not be permitted". UNESCO, Universal Declaration on the Human Genome and Human Rights (1997), $<$ http://www.unesco.org/ibc/uk/genome/projet/index.html>. Similarly, the World Health Organization (WHO) has adopted a resolution affirming "that the use of cloning for replication of human individuals is ethically unacceptable and contrary to human integrity and morality." WHO Doc. WHA50.37 (May 14, 1997). No doubt further steps will need to be considered on a global level.

${ }^{50}$ One can imagine a host of other potential problems of the future. In the field of immigration and refugee law, if the use of biotechnology for medical treatments in one group of states vastly outpaces in development in other states, there may emerge a new category of persons known as "medical refugees." Or, if scientists can some day screen individuals genetically for their disposition to engage in criminal behavior, legislators may be tempted to use the information to deny the admission of refugees on grounds of national security or safety. U.S. law currently calls for refusal of asylum or for removal when an alien is shown to have engaged in a "serious nonpolitical crime" prior to the alien's arrival in the United States, see, e.g., INS v. Aguirre-Aguirre, 526 U.S. 415 (1999), regardless of whether the alien has completed his or her sentence, presumably on grounds that the prior act is predictive of future behavior.

${ }^{51}$ See Michael J. Malinowski, Globalization of Biotechnology and the Public Health Challenges Accompanying It, 60 AlB. L. REV. 119 (1996). 
arisen with existing biotechnology applications in the field of pharmaceuticals and agriculture, in the hope that the ensuing analysis will prove useful in addressing concerns about potential applications in the future. The principal contemporary concerns may be placed in six general categories: (1) equitable concerns regarding the patenting of genetically modified products; (2) the need to notify an importing state of genetically modified products and the degree of detail provided in such notification; (3) the circumstances under which the importing state may refuse to permit genetically modified imports consistent with international trade rules; (4) liability for the adverse effects of genetically modified exports upon human health or the environment of the importing state; (5) liability for the adverse effects of genetically modified products that, while wholly produced and consumed in the originating state, nevertheless have adverse effects on the human health or environment of adjacent states; and (6) the potential loss to present and future generations from the long-term decline in global biological diversity caused by the release of genetically modified products into the environment. The efforts of existing global treaty regimes to grapple with each concern is briefly discussed in turn.

\section{Equitable Concerns Regarding the Patenting of Genetically Modified Products}

Particularly in the area of pharmaceuticals and agriculture, there are important concerns that arise in the patenting of genetically modified products. Those concerns largely play upon two themes. First, developed states argue that intellectual property in genetically modified products must be protected so as to promote the costly research and development of such products, while developing states counter that such protection will make access to the products very expensive if not prohibitive for 
developing states, and in any event is inappropriate for life forms. Second, developed states desire relatively unrestricted access to the rich genetic diversity found in developing states as source material for genetic engineering, while developing states argue that the fruits of genetic resources uncovered in developing states should be equitably shared with them. ${ }^{52}$ Each theme is addressed in turn.

With respect to the first theme-concerning whether to grant and protect intellectual property rights in genetically modified products - U.S. intellectual property law generally does not acknowledge ownership or use of naturally occurring or socially maintained materials or information in the public domain, such as genetic resources. Consequently, access to such genetic resources is generally unrestricted. However, once novel products or processes are developed from genetic resources, then U.S. law may provide intellectual property protection. Thus, a naturally occurring substance, whether living or inanimate, in principle can be patented if it is isolated from its surroundings, identified and made available for the first time, and has a useful purpose. Further, patents may be issued for chemical compounds corresponding to genes or nucleotide sequences when isolated and made available for a useful purpose.

52 Developing states can try to dedicate resources to develop biotechnology applications themselves, but the costs and expertise required make widespread biotechnology research and development prohibitive. For instance, of thirty-four states conducting field trials of transgenic crops from 1986 through 1995, more than half (eighteen) were developed states, while only three were states that were formerly centrally planned and thirteen were developing states. Of the 3,647 tests conducted during that period, more than half $(1,952)$ were in the United States and more than a fourth in Belgium, Canada, France, the Netherlands, and the United Kingdom $(1,082)$. In Africa, only twenty-five field tests were conducted in three African states: Egypt, South Africa, and Zimbabwe. See CLIVE JAmes \& Anatole F. Krattiger, Global Review of the Field Testing and Commercialization of Transgenic Plants, 1986 to 1995: The First Decade of Crop Biotechnology 4-5 (Int'l Serv. for the Acquisition of Agri-biotech Applications Briefs No. 1, 1996). 
Under this rationale, U.S. intellectual property protection has been extended to include microorganisms, as well as genetically modified plant and animal breeds. Although the U.S. Patent and Trademark Office initially had doubts about the ability to patent micro-organisms, the U.S. Supreme Court decided in 1980 that it is possible to issue a patent for such a product under U.S. law ${ }^{53}$ so long as it could be said that someone had invented or discovered a new and useful "manufacture" or "composition" of matter having a distinctive name, character, and use. ${ }^{54}$ Similarly, new plant and animal breeds traditionally have been protected in the United States under intellectual property laws, and this protection extends to genetically modified plants and animals. ${ }^{55}$

5335 U.S.C. $\$ 101$ (1994).

${ }^{54}$ Diamond v. Chakrabarty, 447 U.S. 303 (1980) (finding that a genetically engineered bacterium capable of breaking down crude oil could be patented). See generally John M. Czarnetzky, Note, Altering Nature's Blueprints for Profit: Patenting Multicellular Animals, 74 VA. L. REV. 1327 (1988). Interestingly, the oil eating bacterium at stake in Chakrabarty was never commercialized. See KRIMSKY \& WRUBEL, supra note 22, at 158. On the generally favorable disposition of U.S. courts and of the policy decisions of the U.S. Patent and Trademark Office toward genetic innovation, see Timothy Caulfield et al., Patent Law and Human DNA: Current Practice, in Legal Rights and Human Genetic Material 117 (Bartha Maria Knoppers et al. eds., 1996).

${ }^{55}$ See, e.g., Ex parte Allen, 2 U.S.P.Q.2d (BNA) 1425 (Bd. Pat. App. 1987), aff'd, 846 F.2d 77 (Fed. Cir. 1988) (allowing patent of an oyster egg with a genetically altered number of chromosomes); Ex parte Hibberd, 227 U.S.P.Q. (BNA) 443 (Bd. of Pat. App. 1985) (allowing patent of a genetically altered type of maize seed). For a recent decisions, see Enzo Biochem, Inc. v. Calgene, Inc., 188 F.3d 1362 (Fed. Cir. 1999) (patentability of “antisense technology," meaning technology used to control expression of a gene in an organism); Pioneer Hi-Bred International, Inc. v. J.E.M. Ag Supply, Inc., 200 F.3d 1374 (Fed. Cir. 2000) (patentability of certain hybrid plants).

In 1987, the U.S. Patent and Trademark Office promulgated a rule that permitted the patenting of higher organisms. 1077 Official Gazette PAt. \& Trademark OfF. 24 (1987). In 1988, the first genetically modified animal patent was issued to Harvard University for a mouse engineered with a gene that made it susceptible to cancer and therefore useful in testing for carcinogens. See Malcolm Gladwell, Harvard Scientists Win Patent for Genetically Altered Mouse; Award Is First to Be Issued for an Animal, WAsH. Post, Apr. 12, 1988, at A1. 
The case of agricultural seeds helps illustrate the significant transnational consequences that can flow from the recognition of such patents on genetically engineered products. At one time, farmers retained seeds from prior harvests to sow new ones, as well as purchased or shared seeds locally. In recent decades, farmers began purchasing seeds nationally and transnationally from large companies but, even then, the fact that plants grown from the seeds produced a second generation of seeds largely left the various strains of seeds available to all farmers for use and experimentation. With the advent of modern biotechnology, however, the control of agricultural seeds may shift from farmers worldwide to just a few multinational biotechnology companies. ${ }^{56}$ When seeds for genetically modified plants are exported by a U.S. company ${ }^{57}$ the foreign importer must enter into a license agreement, whereby the importer is licensed to grow a crop for a single generation. That crop, once produced, is the property of the licensee. The genes of the crop, however, remain the property of the U.S. company and are protected under U.S. patents. If the importer attempts to produce a second generation of the crop, the importer violates the license agreement and U.S. patent law. The asserted reason for the patent protection is to recoup developmental costs. ${ }^{58}$

${ }^{56}$ Principal companies holding patents on newly engineered agricultural products and services include AgrEvo, Agrigenetics, Cargill Seed, Dupont, Hoechst-Roussel, Monsanto, Novartis Agribusiness Biotechnology, and Pioneer Hi-bred International. As an example of the scale of these companies, Monsanto maintains the largest biotechnology research center in the world; a 210-acre complex outside St. Louis, Missouri featuring 250 separate laboratories, 100 room-sized plant growth chambers, and two acres of greenhouses arrayed on its roof. See Rick Weiss, supra note 25.

${ }^{57}$ In 1999, the United States produced approximately $72 \%$ of the world's commercially produced transgenic crops, followed by Argentina (17\%) and Canada (10\%). See Robert Paarlberg, The Global Food Fight, Foreign AFF., May-June 2000, at 24, 26.

${ }^{58}$ Monsanto estimates that it can take ten years and several hundred million dollars to create a commercially viable seed. See Weiss, supra note 25 . The same development costs are associated with 
How does the U.S. company know that a plant grown abroad was derived from its genetically modified seeds? Typically, in addition to genetically modifying the seed to make a better plant, the U.S. company also introduces into the seed a "marker" gene that allows the company to identify its plants and any offspring. ${ }^{59}$ Further, the license agreement, sometimes referred to as a "technology use agreement," allows the U.S. company to perform tests in the importer's fields at will to determine whether there is patent infringement. For example, Monsanto has hired retired Canadian Mounted Police to conduct random DNA tests on its Canadian customers, and has begun suing (and settling with) those found non-compliant, as well as suing non-customers on whose land plants with marker genes are found ${ }^{60}$ Moreover, it now appears possible to bio-engineer seeds so that their plants produce sterile seeds ("terminator" genes), thus precluding the possibility of a second generation, although this technology is still several years from widespread commercial application. ${ }^{61}$

developing pharmaceuticals or drugs. For instance, studies of the bovine growth hormone discussed supra, note 26 , reportedly involved more than three hundred studies on more than twenty-two thousand dairy cows. See KRIMSKY \& WruBEL, supra note 22, at 166.

${ }^{59}$ Use of marker genes has also been criticized on other grounds. The most commonly used marker is a bacterial gene for antibiotic resistance. Widespread use of such a gene, it is feared, could exacerbate the problem of antibiotic resistence by moving from the genetically modified organism into the environment generally, making disease-causing bacteria resistant to antibiotics.

${ }^{60}$ See Weiss, supra note 25.

${ }^{61}$ The system, called a "technology protection system," forces plants to produce a toxin that is fatal to their own seed but harmless to humans. Critics charge that pollen from these plants might transmit the gene to other plants, making them sterile as well. Supporters note that the technology can be used for self-pollinating plants that rarely mate with other plants; further, even if other plants are made sterile, they would not pass along the gene and would die out. See Robert F. Service, SeedSterilizing 'Terminator Technology' Sows Discord, 282 ScI. 850 (1998); Rick Weiss, Sowing Dependency or Uprooting Hunger?, WASH. Post, Feb. 8, 1999, at A9. Opposition to such technology led Monsanto in 1999 to announce that it would make no effort to market "terminator" 
With respect to intellectual property laws in other developed states, there appears to be consensus that intellectual property protection cannot be extended to genetic resources merely as found in nature, and to which there has been no intervention of human ingenuity, such as by isolating the resource in a pure form. ${ }^{62}$ Further, most developed states have followed the U.S. approach in allowing patents for micro-organisms and genetically modified plants and animals, as well as for nucleotide sequences. ${ }^{63}$ To that end, several states have adopted a treaty designed to harmonize the amount of disclosure necessary to obtain a patent of a living organism. ${ }^{64}$ Like the United States, these states favor strong intellectual property protections for genetically modified products in both the exporting state and the importing state, since this is seen as a key basis for technology transfer agreements and foreign investment in technology-importing states. ${ }^{65}$ Most attention is paid to the ability to patent products or information derived from genetic resources, although other protections, such as plant breeders' rights

seeds, but other companies are continuing related research. See Barnaby J. Feder, Monsanto to Bar a Class of Seeds, N.Y. TIMES, Oct. 5, 1999, at A1.

${ }^{62}$ Philip W. Grubb, Patents for Chemicals, Pharmaceuticals and Biotechnology 213-14 (1999).

${ }^{63}$ OECD REPORT, supra note 36, at 20; GRUBB, supra note 62, at 227. For the European Union, see Parliament/Council Directive on the Legal Protection of Biotechnological Inventions 98/44, 1998 O.J. (L 213) 13; Robin Nott, “You Did It!": The European Biotechnology Directive at Last, 20 Eur. InTELl. Prop. Rev. 347 (1998).

${ }^{64}$ See Budapest Treaty on the International Recognition of the Deposit of Microorganisms for the Purposes of Patent Procedure, Apr. 28, 1977, 32 U.S.T. 1241, 17 I.L.M. 285. The Budapest Treaty entered into force in 1980 and as of 1998 has been ratified by 42 states. The treaty establishes a list of international depositary authorities where a patent applicant may make a single deposit of the new genetic material. Once deposited, the material is available to the public so that others may determine whether a genetic material they have invented is novel.

${ }^{65}$ OECD REPORT, supra note 62, at 8. 
and trade secret, can be invoked as well.

Developing states are well aware of the benefits of genetically engineered products, whether they be insect-resistant sweet potatoes in Vietnam, or disease-free, vaccine-laced bananas in eastern and central Africa or papayas in southeast Asia. Yet many developing states have resisted recognition of intellectual property rights in such products. ${ }^{66}$ This resistance turns in part on an ethical or moral belief that life forms, as a general matter, should not be treated like an invention. Life forms are special and different and not reducible to property rights that may be possessed by some and denied to others. To the extent certain property rights are accorded to life forms, many developing states perceive an imbalance in Western intellectual property regimes, which deny intellectual property rights for medicinal or agricultural knowledge, skills, and materials which have been handed down over generations. Arguably the new biotechnology "invention" is just a further step (albeit a radical one) in our comprehension of a genetic evolution spanning millennia.

Moreover, developing states are concerned that granting intellectual property rights for genetically engineered products will allow just a few multinational, biotechnology companies in the developed world to command extraordinary license fees for products and services of critical need to the developing world.. They note that such multinational corporations have vastly superior capital and

${ }^{66}$ A state is generally free to develop its own policy towards patents and their enforcement, subject to obligations arising under international agreements. Those agreements principally prevent a state from discriminating against foreign nationals in the application of its patent laws and clarify priority filing dates for patents or trademarks filed abroad. See The Paris Convention for the Protection of Industrial Property, opened for signature Mar. 20, 1883, revised July 14, 1967, 21 U.S.T. 1630 \& 24 U.S.T. 2140, 828 U.N.T.S. 305 [hereinafter Paris Convention]; Patent Cooperation Treaty, June 19, 1970, 28 U.S.T. 7645, 1160 U.N.T.S. 231. 
other resources in the race to patent genetically modified products. Even now, before the biotechnology revolution is in full swing, twenty percent of the world's population in the developed states have seventy-four times as much income as the poorest 20 percent of the world's population, up from thirty times as much in $1960 .{ }^{67}$ While ideally biotechnologies would be developed in a manner that would allow returns on investment across the globe, various factors instead presage a widening biotechnology gap between developed and developing states: the narrow genetic base of biotechnology innovations; the increasing privatization of biotechnology research and development (and concomitant decline in public sector support for agricultural research); the extensive capital requirements of biotechnology research and development; and the need to recoup those costs through pricing strategies built on intellectual property protections. ${ }^{68}$ It may be that only the wealthier developing states or developing states with large national markets — such as Brazil, China, India, Indonesia, and Thailand — will be able to pursue biotechnological development.

If multinational companies of the developed world win the race and obtain exclusive control over the most successful genetically modified products, developing states envisage two possible scenarios unfolding. In one scenario, a new age of "bio-colonialism" emerges, where the nationals of developing states become dependent on those products, resulting in their meager earnings being siphoned off to the developed world in the form of expensive license fees. While this is of concern to

${ }^{67}$ See United Nations Development Programme, Human Development Report 1999 at 36 (1999), <http://www.undp.org/hdro/>.

${ }^{68}$ See David R. Lee, A Perspective on Socioeconomic Research on Plant Biotechnology Transfer for Developing Countries, in Plant Biotechnology Transfer to DeVeloping COUNTRIES, supra note 30, at 58. 
developing states, it should be of concern to the developed world as well; economic distress inevitably leads to conflict. ${ }^{69}$ In the other scenario scenario, even if developing states are willing to pay expensive license fees, they may not be able to afford them, given the difficulty developing states already have in paying for traditional, non-engineered products. Moreover, if unable to pay, products of the greatest use for the developing world may not even be invented by developed countries. Indeed, while the notion of feeding the world resonates well for those favoring biotechnology, why would biotechnology companies undertake the costs of genetically engineering crops such as cassava and cowpea, little known in the developed world, but critical for a number of the world's poorest states? Genetic engineering may have a role to play in "feeding the world" or "curing the world," but it is not clear whether the role will be a major one absent incentives and structures beyond typical market forces. ${ }^{70}$ Consequently, while developing states recognize that intellectual property rights may be necessary in the developed world to help recoup the research costs of biotechnology companies, they believe that denying such rights in the developing world would make it easier for them to obtain the benefits of biotechnology.

As a result of these attitudes, developing states initially tried to have genetic material declared

${ }^{69}$ See Ethan B. Kapstein, Distributive Justice As an International Public Good: A Historical Perspective, in Global Public Goods 88, 112 (Inge Kaul et al. eds., 1999).

70 See Transgenic Plants And World Agriculture, supra note 31, at 23-24. Similar problems arise in the context of pharmaceuticals. North America, Europe and Japan account for 80\% of world drug sales, while Africa accounts for $1 \%$. Thus, a drug capable of treating advanced sleeping sickness - one of the historic scourges of Africa-was recently deemed unprofitable and discontinued by its Western manufacturer since it is useless against cancer, the target of interest to the developed world. See Donald G. McNeil Jr., Drug Makers and the Third World: A Case Study in Neglect, N.Y. Times, May 21, 2000, at 1. 
part of the common heritage or province of all mankind, ${ }^{71}$ in the spirit of instruments relating to the deep seabed, space, and geographical/cultural landmarks. ${ }^{72}$ Those attitudes pervaded discussions at the World Intellectual Property Organization (WIPO), the U.N. agency charged with overseeing global intellectual property conventions. ${ }^{73}$ In recent years, however, developing states have come to see ownership of genetic materials located within their territory as a means for extracting benefits from those who use them for biotechnology applications. Consequently, attitudes have shifted in favor of viewing rights in genetic material as in some sense restricted, making it more difficult for biotechnology companies and universities to obtain genetic supplies from foreign sources. ${ }^{74}$

Differences among states over whether to accord intellectual property rights in genetically engineered products were aired during the course of the negotiations that led to the 1994 Uruguay

${ }^{71}$ In 1983, the U.N. Food and Agriculture Organization (FAO) developed a non-binding undertaking dealing with access to plant genetic resources for food and agriculture that declared genetic resources to be "a heritage of mankind to be preserved, and to be freely available for use, for the benefit of present and future generations." International Undertaking on Plant Genetic Resources for Food and Agriculture, pmbl., FAO Res. 8/83, 22nd Sess. (1983). For background, see Harold J. Bordwin, The Legal and Political Implications of the International Undertaking on Plant Genetic Resources, 12 EcOL. L.Q. 1053 (1985). Some 113 states have adhered to the Undertaking, which is currently under revision at the FAO.

${ }^{72}$ See U.N. Convention on the Law of the Sea, opened for signature Dec. 10, 1982, art. 136, S. TREATy Doc. No. 103-39, at 140 (1994), 21 I.L.M. 1261, 1293; Treaty on Principles Governing the Activities of States in the Exploration and Use of Outer Space, Including the Moon and Other Celestial Bodies, opened for signature Jan. 27, 1967, art. 1, 18 U.S.T. 2410, 2412, 610 U.N.T.S. 205, 207; Convention for the Protection of the World Cultural and Natural Heritage, Nov. 23, 1972, pmbl., 27 U.S.T. 37, 40, 1037 U.N.T.S. 151, 152.

${ }^{73}$ See David G. Scalise \& Daniel Nugent, International Intellectual Property Protections for Living Matter: Biotechnology, Multinational Conventions and the Exception for Agriculture, 27 CASE W. RES. J. INT’L L. 83, 107 (1995).

${ }^{74}$ See infra note 238 and accompanying text. 
round agreements. Unfortunately, the hard-fought language developed in those negotiations leaves does not expressly address the treatment of genetically engineered products and thus leaves many questions still unanswered. The Agreement on Trade-Related Aspects of Intellectual Property Rights provides that all parties are to accord protections for "any inventions, whether products or processes, in all fields of technology, provided that they are new, involve an inventive step and are capable of industrial application. ${ }^{.75}$ However, patents may be prohibited to protect ordre public or morality, provided there is a justification exceeding the mere prohibition in national law. ${ }^{76}$ Further, "plants and animals other than micro-organisms, and essentially biological processes for the production of plants and animals other than non-biological and microbiological processes" may be excluded from protection, provided that plant varieties are protected by patents and/or by an effective sui generis system. ${ }^{77}$

${ }^{75}$ Agreement on Trade-Related Aspects of Intellectual Property Rights, Apr. 15, 1994, Marrakesh Agreement Establishing the World Trade Organization [hereinafter WTO Agreement], Annex 1C, art. 27(1), Legal Instruments - Results of the URUguAy Round vol. 31; 33 I.L.M. 81, at 1208 (1994) [hereinafter TRIPS Agreement] (emphasis added). The Paris Convention established the principle of non-discriminatory treatment of foreign nationals with respect to whatever intellectual property protection a state party may provide, but does not establish any minimum standards for the protection of intellectual property.

76 TRIPS Agreement, art. 27(2).

${ }^{77} I d$., art. 27(3)(b). The requirement for protection of plant varieties can probably be met by a state joining the International Union for the Protection of New Varieties of Plants, Dec. 2, 1961, revised Nov. 10, 1972, Oct. 23, 1978, \& Mar. 19, 1991, 33 U.S.T. 2703, 815 U.N.T.S. 89 (UPOV convention). The UPOV convention protects plant breeders' exclusive marketing rights where a plant variety satisfies requirements of novelty, distinctness, uniformity, and stability, but the protections are different from the patenting of genetic material. First, while the UPOV convention precludes resale of seeds from harvested crops, it allows a farmer to reuse them in future seasons, subject to express authorization of the breeder, although a government may exempt the breeder from obtaining such authorization so long as the "legitimate interests of the breeder are protected" (arts. 14 \& 15). Second, the UPOV convention only protects a variety from further change if that change is so small as to leave the new variety "essentially derived" (art. 14). Based on the language of Article 14, this protects a plant 
Since the language does not expressly address genetically modified products, it seems likely that states may interpret it in different ways. On the one hand, patents for living organisms in all likelihood will remain prohibited in some states, and the TRIPS Agreement allows the exclusion of organisms from protection provided that plant varieties are protected. For those states, they will likely interpret the TRIPS Agreement as also allowing the exclusion of patent protection for a newly engineered gene.

On the other hand, that engineered gene can be new, can involve an inventive step, and can be capable of industrial application, and thus apparently can be an invention that, once patented, must be protected under the TRIPS Agreement unless there is an applicable exclusion. It would seem that the patent cannot be excluded from protection solely on the grounds that it is a life form, since the exclusion in the TRIPS Agreement does not cover micro-organisms and genes are not whole organisms. States wishing to deny such protection alternatively might seek to argue that it may do so to protect ordre public or morality. Yet it is unclear whether such a denial can be justified under the TRIPS Agreement with respect to, say, the gene used to create vitamin-enriched rice, where there is no scientific basis for

variety from being further transformed by genetic engineering. What is less, clear, however, is whether it protects genes within a variety. In other words, a biotechnology company might find it difficult to fully protect their product using plant breeders' rights, since those rights probably are not violated if another company removes the gene of a genetically modified variety of rice and transfers it to another variety of rice or other product. Only by also patenting the gene itself could the transfer be prohibited.

Provisions similar to those of the TRIPS Agreement appear in the Convention on the Grant of European Patents, Oct. 5, 1973, 1065 U.N.T.S. 199, art. 53. Interpretation of those provisions has been complex, with the European Patent Office issuing seemingly inconsistent opinions on the ability to patent genetically engineered plants and animals. See Darrell G. Dotson, Comment, The European Controversy Over Genetic-Engineering Patents, 19 Hous. J. INT'L L. 919 (1997). A recent decision clarifying that patents are available is Novartis II/Transgenic Plant, Case G0001/98 (Eur. Pat. Off. Enlarged Bd. App. Dec. 20, 1999). 
regarding the gene or the rice as harmful to human health or the environment.

Thus, while the TRIPS Agreement may not force states to implement strong intellectual property protection for genetically modified organisms, it may force states to achieve the same result by protecting patented genes. This interpretation, however, is not free from challenge and will likely lead to difficulties in implementation. In the final analysis, the negotiators of the TRIPS Agreement, burdened with the enormous task of addressing the wide range of issues concerning trade and intellectual property, fell short in providing clear guidance on how to reconcile the competing interests of states and private actors in the field of transnational biotechnology. The resulting ambiguous treaty norms may influence transnational behavior, but appear to fall short of adequately regulating it.

With respect to the second theme introduced at the beginning of this section, further concerns have arisen regarding the access to genetic source material from which genetically engineered products are developed, as well as the distribution of benefits (in the form of financial or technology transfers) to those traditionally associated with the genetic source material. This issue typically arises when genes are appropriated not from the state that manipulates, patents, and sells the genetically modified product but, rather, from some other state. Biotechnology companies wish to "bio-prospect" in the ecologically diverse systems often found in the developing world, while developing states charge that their genetic resources, including the knowledge of their indigenous people, are being "stolen" by foreign private companies to engineer new products. ${ }^{78}$ In recent years, the rights of indigenous people have received

\footnotetext{
${ }^{78}$ See Andrew Jacoby \& Charles Weiss, Recognizing Property Rights in Traditional Biocultural Contribution, 16 St An. EnvTL. L.J. 74 (1997); Solomon R. Benatar, A Perspective from Africa on Human Rights and Genetic Engineering, in THE GENETIC REVOLUTION AND Human Rights, supra note 18, at 159, 170 (“Attempts to patent products developed with
} 
extensive international attention; ${ }^{79}$ allowing them to share in the benefits of genetic resources that they

have used as medicines and food for generations is considered of high priority within the developing

world. Raw genetic source materials and their derivatives can command prices ranging from just a few

cents to millions of dollars per kilogram; yet once manipulated, they inevitably command far higher

information derived from the practices of indigenous healers, and eagerness to patent components of the human genome for exclusive economic gain are seen as new forms of exploitation that exclude considerations of the humanity of those living in economic misery.") The oft-cited example of this is the U.S. patent by W.R. Grace Company on a process for extracting a chemical from the seeds of the neem tree, a botanical cousin of the mahogany tree that is found in India and has been used for centuries for medicinal and other purposes. See National Research Council, NeEm: A Tree for Solving Global Problems (1992); John Tanner, India: U.S. Giant, Peasants Battle for "Blessed Tree”, InTER Press SERVICE Glob Al Info. Network, Oct. 12, 1993, available in 1993 WL 2534808 .

${ }^{79}$ There are more than 200 million indigenous people in the world, many of whom live in ecosystems considered rich depositories of unexploited resources. See AlEXANDRE Kiss \& DinaH Shelton, International EnVironmental Law 178 (2d ed. 2000). Various conventions and "soft-law" instruments acknowledge and promote these rights. See Agenda 21: Program of Action for Sustainable Development, Rio de Janeiro, U.N. Doc. A/CONF.151/26, ch. 26 (3 vols. 1992); Rio Declaration on Environment and Development (June 14, 1992), principle 22, U.N. Doc. A/CONF.151/5/Rev.1 (1992), reprinted in 31 I.L.M. 874, 879 (1992); International Labour Organization Convention (No. 169) Concerning Indigenous and Tribal Peoples in Independent Countries, June 27, 1989, 28 I.L.M. 1382 (1989) (this convention currently has 14 parties); International Labour Organization Convention (No. 107) Concerning the Protection and Integration of Indigenous and Other Tribal and Semi-Tribal Populations in Independent Countries, 328 U.N.T.S. 247 (this convention currently has 27 parties). An open-ended inter-sessional working group of the U.N. Commission on Human Rights currently has under consideration a draft declaration on indigenous peoples. See Henry J. Steiner \& Philip Alston, International Human Rights in Context 1301-04 (2d ed. 2000).

In addition, there are various relevant instruments that ascribe to the "right to development" the ability of peoples both to "full sovereignty over all their natural wealth and resources," U.N. General Assembly Declaration on the Right to Development, G.A. Res. 41/128, annex, U.N. GAOR, 41st Sess., Supp. No. 53, at 186, U.N. Doc. A/41/53 (1987), and the ability to enjoy the benefits of scientific and technological processes. See Additional Protocol to the American Convention on Human Rights in the Area of Economic, Social and Cultural Rights (Protocol of San Salvador), Nov. 17, 1988, art. 14(1)(b), O.A.S. T.S. 69, reprinted in 28 I.L.M. 156 (1989) (corrections at 28 I.L.M. 573 \& 1341 (1989) (this protocol currently has 11 parties). 
prices. ${ }^{80}$ As noted above, while international intellectual property regimes protect patents in many genetically modified products, they largely do not protect the underlying genetic resource, or the knowledge and innovations of indigenous people, which are deemed to be in the public domain. ${ }^{81}$

The negotiators of the 1992 Convention on Biological Diversity (Biodiversity Convention) ${ }^{82}$ attempted to grapple with these concerns about ensuring access to genetic source material while at the same time promoting a fair distribution of the benefits that might accrue from genetically engineered

${ }^{80}$ See Kerry ten Kate \& Sarah A. Laird, The Commercial Use of Biodiversity 2 (1999); see also Walt Reid et al., A New Lease on Life, in BIODIVERsity ProspeCting: Using Genetic Resources for Sustainable Development 18 (Walt Reid et al. eds., 1993) ("even a relatively small share of net profits may amount to extremely large revenues for a developing country.").

${ }^{81}$ An analogue to this may be seen in California law with respect to genetic information obtained from humans. California law provides that a person from whom genetic information is taken has no property rights to that information, even if used to produce a commercially viable product, absent a contract to that effect. See Moore v. Regents of the Univ. of Cal., 51 Cal. 3d 120, 793 P.2d 479, 271 Cal. Rptr. 146 (1990). In Moore, the plaintiff had unique genetic qualities that were obtained by a doctor from diseased material removed from the plaintiff. The doctor then developed a commercially viable product. The court found that the plaintiff had no property interest in the product, but found that the doctor may have breached a fiduciary duty by failing to advise the patient of his intent to use the genetic material commercially. Consequently, new products made from the genetic material may be patented and the person from which the genetic material originated has no property rights in that patent.

${ }^{82}$ Convention on Biological Diversity, June 5, 1992, 31 I.L.M. 818, 823. As of October 2000, 178 states have ratified or acceded to the Convention, an extraordinary level of adherence by any measure. The overall objectives of the Convention are:

the conservation of biological diversity, the sustainable use of its components and the fair and equitable sharing of the benefits arising out of the utilization of genetic resources, including by appropriate access to genetic resources and by appropriate transfer of relevant technologies, taking into account all rights over those resources and to technologies, and by appropriate funding.

Id., art. 1. 
products based on that material. In addition to articles in which Parties commit to try to preserve biological diversity through various means, the Convention contains an article on access to genetic resources, ${ }^{83}$ an article on access to and transfer of technology, ${ }^{84}$ and an article on the handling of biotechnology and distribution of its benefits. ${ }^{85}$

Unfortunately, formal negotiation of the Convention began in 1991 and was completed hurriedly in time for the 1992 Rio Summit. The hurried pace left insufficient time for the disparate views of states to converge, resulting in a text that is often times unclear, ambiguous or even contradictory, including on the issues of intellectual property and sharing of benefits. The United States declined to sign the convention at 1992 U.N. Conference on Environment and Development in Rio de Janeiro,

${ }^{83}$ Article 15 confirms the sovereign right of states over their natural resources, including the authority to determine access to genetic resources by national legislation. Each Contracting Party "shall endeavour to create conditions to facilitate access to genetic resources for environmentally sound uses by other Contracting Parties" on mutually agreed terms and subject to prior informed consent of the Contracting Party. Id. art. 15, at 828.

${ }^{84}$ Under Article 16, each Contracting Party undertakes “to provide and/or facilitate access for and transfer to other Contracting Parties of technologies that are relevant to the conservation and sustainable use of biological diversity or make use of genetic resources," so long as they do not cause significant damage to the environment. Moreover, such transfer of technology to developing states "shall be provided and/or facilitated under fair and most favorable terms, including on concessional and preferential terms where mutually agreed," although only where "consistent with the adequate and effective protection of intellectual property rights." Id. art 16, at 829.

${ }^{85}$ Under Article 19, each Contracting Party shall "provide for the effective participation in biotechnological research activities by those Contracting Parties, especially developing countries, which provide the genetic resources for such research," as well as "take all practicable measures to promote and advance priority access on a fair and equitable basis by" such parties "to the results and benefits arising from" such resources. $I d$. art. 19, at 830 . 
ultimately citing among its concerns the treatment of intellectual property and benefits. ${ }^{86}$ The initial resistance of U.S. industry to the Convention turned in large part on a belief that the Convention failed to recognize the positive role of intellectual property in facilitating technology transfer (as well as its role in promoting cooperative research and development by private entities), and requires too much government interference in those private transactions. From their perspective, the objective of intellectual property rights (promoting costly research and its commercialization) should not be undermined by governments forcing private actors to relinquish their rights; rather, it should be left to private transactions between private actors and those providing the genetic resources to negotiate an equitable arrangement, which will occur in conditions where intellectual property is protected. ${ }^{87}$ Other

\footnotetext{
${ }^{86}$ See David Hunter, James Salzman, \& Durwood Zaelke, International EnVironmental Law ANd Policy 957-58 (1998).

${ }^{87}$ In particular, U.S. industry has pointed to the final provision of Article 16 of the Convention, which appears to allow a Contracting Party to insist that intellectual property rights cannot interfere with the transfer to it of technology and profits that are within the scope of the Convention. Article 16(5) of the Convention reads:
}

The Contracting Parties, recognizing that patents and other intellectual property rights may have an influence on the implementation of this Convention, shall cooperate in this regard subject to national legislation and international law in order to ensure that such rights are supportive of and do not run counter to its objectives.

Id. art. 16(5), at 829. Further, Article 19 appears to require extensive foreign participation in biotechnological research without regard to protection of intellectual property or confidential business information. For a discussion by the lawyer for the U.S. delegation, see Melinda Chandler, The Biodiversity Convention: Selected Issues of Interest to the International Lawyer, 4 COLO. J. INT'L ENVTL. L. \& POL'Y 141, 162-64 (1993).

Even after signing the convention, the Administration expressed concerns about protection of intellectual property rights when transmitting the convention to the Senate. See Message from the President of the United States Transmitting the Convention on Biological Diversity, S. TREATY Doc. No. 103-20 (1993), available in 1993 WL 796847 (stating that the Administration will "strongly resist any actions taken by Parties to the Convention that lead to inadequate levels of protection of intellectual 
developed states, however, have ratified the Convention, taking the view that intellectual property rights are preserved under the Convention, ${ }^{88}$ an interpretation that most U.S. biotechnology companies eventually reached as well. ${ }^{89}$ After taking office in 1993, President Clinton signed the convention and submitted it to the Senate for advice and consent. ${ }^{90}$ The transmittal package included a letter from the Department of State asserting that

with respect to technology subject to patents and other intellectual property rights, the Convention requires all Parties to ensure that access to or transfer of technology is consistent with the adequate and effective protection of intellectual property rights. The United States will strongly resist any actions taken by the Parties to the Convention in derogation of this obligation. $^{91}$

property rights, and will continue to pursue a vigorous policy with respect to the adequate and effective protection of intellectual property rights in negotiations on bilateral and multilateral trade agreements").

${ }^{88}$ See generally OECD REPORT, supra note 36, at 30 (technology transfer under the Convention "will usually include the licensing of some form of propriety right obtained either under an established statutory form of intellectual property or deriving from the possession of secret know-how and/or proprietary biological material.”) It has been noted that for Article 16 to be interpreted as requiring involuntary transfer of technology from developed states to developing states, it must also be the case that Article 15 must be interpreted as requiring involuntary transfer of genetic resources from developing states to developed states, an outcome no developing state would be prepared to accept. See Michael A. Gollin, The Convention on Biological Diversity and Intellectual Property Rights, in Biodiversity Prospecting: Using Genetic Resources for Sustainable Development 289, 295 (1993).

${ }^{89}$ HUNTER ET AL., supra note 86, at 958.

${ }^{90}$ See S. Treaty Doc. No. 103-20 (1993).

${ }^{91} I d .$, at VI-VII. 
As of October 2000, the U.S. Senate has not provided its advice and consent, thus leaving the United States (and U.S. companies) outside the scope of its terms.

The Convention represented an important step in the development of the transnational biotechnology regime, but it has been criticized as containing very general provisions that leave much unsaid. ${ }^{92}$ As was the case with the TRIPS Agreement, the negotiators were unable to confront squarely the competing interests of states and private actors, resulting in ambiguous treaty norms that may influence transnational behavior, but fall short of regulating it. With respect to the sharing of benefits derived from genetic resources of a developing state, the Convention largely leaves the matter to private contracting between the relevant actors, without providing any framework, guidelines, or principles for how such contracting should proceed, nor for grappling with certain problems. For instance, the transaction costs involved in such arrangements can be quite high, in terms of identifying potential sources of genetic material, negotiating and concluding agreements, and then waiting for the long timelag before research and development on a genetic resource yields economic benefits. Further, while it may be possible for a developing state to negotiate a contract for the provision of a genetic resource located within its state, any given genetic resource (such as a plant or several varieties of it) may exist in multiple states or in existing ex situ collections. If so, which states have rights to compensation? What if

92 See, e.g., David R. Downes, New Diplomacy for the Biodiversity Trade: Biodiversity, Biotechnology, and Intellectual Property in the Convention on Biological Diversity, 4 Touro J. Transnat'L L. 1 (1993); Ashish Kothari, Beyond the Biodiversity Convention: A View From India, in Biodiplomacy: Genetic Resources and International Relations 67 (V. Sanchez \& C. Juma eds., 1994) (“[E]ven with its weak and inadequate terminology, it provides some basis for action, some possibilities of reversing many historical inequities between and within countries. For this possibility to become manifest, however, a considerable effort at re-interpreting and looking beyond the Convention is necessary."). 
states underbid each other to obtain the contract with the bioprospecting company? Should a multistate contract be developed? If so, will the transaction costs harm the economic viability of biotechnology research? Finally, and perhaps most importantly, developing states (or their indigenous groups or poor) are apt to sell rights to genetic resources cheaply, not because they attribute a low value to such resources, but because they are poor. Moral or equitable arguments may be made that the market, in this context, is not an effective instrument for serving either present or future generations.

Thus, there are various equitable concerns regarding the patenting of genetically modified products, concerns that existing international law and structures do not fully address. Indeed, there is considerable tension between the regulatory regime envisaged by the TRIPS Agreement and that envisaged by the Convention on Biological Diversity. At the same time, there are various interests of both state and non-state actors involved. While developing states, and their farmers and indigenous groups, worry about "bio-colonialism" and development of substitute goods through biotechnology, biotechnology exporting states and their companies worry about developing states denying access to genetic resources and denying protection for intellectual property rights in biotechnology applications once developed. While biotechnology companies are largely profit-driven, they cannot be immune to calls from non-governmental groups, including relief organizations and other activists, for broader recognition of the inequity in failing to pursue and to make available on a low-cost/no-cost basis biotechnology applications of critical importance to the developing world. Indeed, failure to heed such calls may very well affect a company's profit margin by leading to boycotts, more stringent government regulation, denial of intellectual property protection, or closing down of a foreign market. 
Transparency Regarding Exports of Genetically Modified Products

A second problem of biotechnology in the transnational sphere concerns the appropriate level of transparency when genetically engineered products are exported from one state to another. Here, too, may be seen sharply competing interests of states and private actors, along with an effort to regulate such interests though development of new treaty norms, ones that ultimately fall short of fully addressing those interests.

To assess the risk of genetically modified products to human health or the environment (or for other reasons), ${ }^{93}$ a state can develop national laws regulating the development and application of such products originating in its territory. ${ }^{94}$ In the case of products imported from abroad, however, the state either needs a sophisticated system for identifying such products at the port of entry ${ }^{95}$ or needs to receive notification from the exporter or the exporting state. Notification of genetically modified content

${ }^{93}$ For instance, certain religious groups (Jewish, Muslim) will wish to know if food products contain genes from animals, such as swine.

${ }^{94}$ Under the Convention on Biological Diversity, the Parties are obliged, as far as possible and appropriate, to:

Establish or maintain means to regulate, manage or control the risks associated with the use and release of living modified organisms resulting from biotechnology which are likely to have adverse environmental impacts that could affect the conservation and sustainable use of biological diversity, taking also into account the risks to human health.

Convention on Biological Diversity, art. 8(g), at 826.

${ }^{95}$ For instance, polymerase chain reaction (PCR) and other methods have been developed to detect novel DNA and proteins contained in products. For a description of PCR, see SMITH, supra note 4 , at $44-46$. 
could be achieved through a labeling system whereby genetically modified products are clearly marked as such. A labeling system could be mandated through enactment of national legislation by the importing state. For instance, beginning in 1997, the European Union passed legislation requiring labeling for certain products composed of or containing genetically modified products. ${ }^{96}$ In 1999, bills were introduced in both houses of the U.S. Congress that would require labeling of foods made with genetically engineered material. ${ }^{97}$

There are, however, difficulties in developing a sensible labeling scheme. States must establish standards for determining (and detecting) genetic content and, unless harmonized, those standards may differ, causing disruptions in trade flows. Further, especially for bulk shipments of commodities, it may be difficult to avoid ubiquitous labels of "may contain genetically modified material," making the labeling scheme essentially meaningless. If greater precision is mandated (or driven by consumer preference), it will be costly, consumers may have difficulty processing the information, ${ }^{98}$ and greater segregation of

${ }^{96}$ See Parliament/Council Regulation 258/97, 1997 O.J. (L 43) 1 (requiring in Article 8(1)(d) that consumers be informed of whether foodstuffs contain "the presence of an organism genetically modified by techniques of genetic modification."); see also Commission Directive 97/35, 1997 O.J. (L 169) 72 (requiring labeling for living genetically modified organisms produced or imported for purposes of introduction into the environment or incorporation into a product); Council Regulation 1139/98, 1998 O.J. (L 159) 4 and Commission Regulation 1813/97, 1997 O.J. (L 257) 7 (regarding labeling of food and food ingredients derived from previously approved, genetically modified soy and maize); Commission Regulation 50/2000, 2000 O.J. (L 6) 15 (removing an exemption for food additives and flavorings); Commission Regulation 49/2000, 2000 O.J. (L 6) 13 (providing a 1\% labeling threshold for "adventitious" or accidental commingling for approved varieties of soy and maize). Directive 97/35 amended an Annex III to Directive 90/220, see infra note 123.

${ }^{97}$ See H.R. 3377, 106th Cong. (1999); S. 2080, 106th Cong. (2000).

${ }^{98}$ See Gillian K. Hadfield \& David Thomson, An Information-Based Approach to Labeling Biotechnology Consumer Products, 21 J. Consumer PoL'y 551, 569 (1998). 
genetically modified products from non-modified products will be necessary. ${ }^{99}$ Further, absent an extensive "plow-to-plate" monitoring system (i.e., from the time a genetically modified organism is planted to the time it is integrated into processed foods), it may be unclear to a producer whether a product derived from numerous sources contains genetically modified content. Thus, any successful labeling system may require an extensive and expensive monitoring system.

In part to promote transparency, parties to the Convention on Biological Diversity negotiated over the course of five years and then adopted on January 29, 2000, the Cartagena Protocol on Biosafety (Biosafety Protocol). ${ }^{100}$ The Biosafety Protocol consists of 40 articles and three annexes, and is an important achievement in many respects. As a general matter, it creates an international framework for addressing the environmental risks and effects of some genetically modified products, setting as its objective contributing

${ }^{99}$ For instance, many of the grain elevators and other storage depots used in the United States do not have multiple bins, nor the necessary capacity to segregate engineered and non-engineered varieties. See Rick Weiss, Food War Claims Its Casualties, WAsh. Post, Sept. 12, 1999, at A1.

${ }^{100}$ Cartagena Protocol on Biosafety to the Convention on Biological Diversity, adopted Jan. 29, 2000, Montreal <http://www.biodiv.org/biosafe/protocol/html> [hereinafter "Cartagena Protocol"]. As of October 2000, 75 states and the EU have signed the Protocol. The convention must be ratified by 50 states before it will enter into force, a process expected to take about two years. See SixtySeven Nations, EU Sign Protocol on Biosafety to U.N. Biodiversity Treaty, 23 Int'1 Envtl. Rep. (BNA) 441 (June 7, 2000). The Convention on Biological Diversity had called upon the Parties to

consider the need for and modalities of a protocol setting out appropriate procedures, including, in particular, advance informed agreement, in the field of the safe transfer, handling and use of any living modified organism resulting from biotechnology that may have adverse effect on the conservation and sustainable use of biological diversity.

Convention on Biological Diversity, art. 19(3), at 830. 
to ensuring an adequate level of protection in the field the safe transfer, handling and use of living modified organisms resulting from modern biotechnology that may have adverse effects on the conservation and sustainable use of biological diversity, taking also into account risks to human health, and specifically focusing on transboundary movements. ${ }^{105}$

Specifically, the Protocol allows trade in genetically modified products to proceed essentially unhindered, subject to two conditions. First, living modified organisms (LMOs) shipped in bulk as commodities (e.g., soy or corn) and that are intended to be used as food, feed, or for processing must be accompanied by documentation stating that such shipments "may contain" LMOs and are not intended for intentional introduction into the environment. Shipments of LMOs destined for "contained use" (e.g., in a laboratory) or for intentional introduction into the environment (e.g., microorganisms for bio-remediation, seeds for planting or live fish for release into lakes) must be accompanied by documentation clearly identifying them as such. ${ }^{106}$

Second, for exports of LMOs that are intended to be introduced into the environment of the importing state, the exporter must also provide detailed information to the importing state in advance of the first shipment, after which the importing state must acknowledge receipt and then provide or deny authorization for the shipment (this is known as the "advanced informed agreement" procedure). ${ }^{107}$ If

${ }^{105}$ Cartagena Protocol, art. 1.

${ }^{106} I d$. art. 18(2).

${ }^{107} I d$., arts. 7-10. The minimum information that the exporter or exporting state must provide is set forth in Annex I. 
authorized, subsequent shipments of the same type of LMOs need not seek authorization, at least until such time as there is a change in the importing state's consent. In what may prove to be its most important legacy, the Protocol further requires the state of import, in deciding whether to authorize the shipment, to undertake "in a scientifically sound manner" a risk assessment "to identify and evaluate the possible adverse effects of living modified organisms on the conservation and sustainable use of biological diversity, taking also into account risks to human health." 108 To that end, the importing state is obliged (or is obliged to require the exporter) to conduct a risk assessment based on certain general principles and methodological steps set forth in the Protocol before authorizing or denying the import and, if authorized, thereafter engage in risk management. ${ }^{109}$ The Protocol also establishes an Internetbased "Biosafety Clearing-House," intended to assist states in the exchange of scientific, technical, environmental, and legal information about LMOs. ${ }^{110}$

The Protocol has its limitations. The Protocol only covers living modified organisms ${ }^{111}$ and is concerned only with their effects on conservation of biological diversity. Efforts to regulate other genetically modified products, such as inanimate foodstuffs $(e . g .$, cookies made from genetically modified grain) and other products (e.g., blue jeans made from genetically modified cotton), were

${ }^{108} I d .$, arts. $10(1) \& 15(1)$

${ }^{109}$ Id., arts. 15-16 \& annex III.

${ }^{110} I d$. art. 20. There already exists a Biodiversity Convention Clearing-House Mechanism, containing links to several thousand Internet pages and documents on biological diversity, located at $<\mathrm{http} / /$ www.biodiv.org/chm>.

${ }^{111}$ A living modified organism is defined as any biological entity capable of transferring or replicating genetic material -including sterile organisms, viruses and viroids - that possesses a novel combination of genetic material obtained through the use of modern technology. Id., art. 3(g)\&(h). 
turned back on the grounds that the Protocol was to focus on the protection of biological diversity, taking into account human health, rather than encompass an exhaustive range of matters, spanning paper goods, textiles, and food safety. Further, all pharmaceuticals are excluded from coverage ${ }^{112}$ while other applications in the medical field also fall outside the scope of the Protocol. Even with respect to LMOs, the advanced informed agreement procedure only applies to LMOs intended for introduction into the environment of the importing state; it does not cover LMOs (live fish or seeds) intended for direct use as food or feed, or for processing, although there are no controls on how the products are in fact used by the importer. The Protocol does not require importing state consent for bulk shipments of LMOs not intended for "introduction into the environment." Such shipments need not be segregated from non-LMOs and need not contain any consumer product labeling; they need only be accompanied by the shipping documentation mentioned above. Further, the advanced informed agreement procedure does not apply with respect to states that are being transited. ${ }^{113}$ Thus, while the Biosafety Protocol is a tremendous step forward in creating transparency for the highest risk category of biotechnology exports-LMOs specifically intended to be introduced into the environment-looking at the issue of transnational biotechnology as a whole, there are considerable gaps in its coverage.

As was the case in the prior sub-section, there are various state and non-state actors concerned about the level of transparency regarding exports of genetically modified products. Here, the divide is less "North/South" oriented; instead, Europe is leading the way in creating mandatory labeling schemes. In Europe, consumer groups find common cause with developing states, relief organizations, and other

$$
\begin{aligned}
& { }^{112} I d ., \text { art. } 5 . \\
& { }^{113} I d \text {., art. } 6 .
\end{aligned}
$$


activists in seeking greater controls over biotechnology companies, albeit for different reasons.

Biotechnology companies and exporters of genetically modified products would rather avoid such labeling schemes, but have incentives to cooperate if the scheme is feasible economically and necessary in order to market their products.

One central uncertainty about such schemes is their relationship to treaties obliging free trade. For instance, the Protocol provides that a state may prohibit the import of a LMO that is intended for introduction into the environment, ${ }^{114}$ and make "take a decision on" (presumably either to permit or to prohibit) the import of LMOs intended for direct use as food or feed, or for processing under its national regulatory framework. ${ }^{115}$ Further, the Protocol provides that decisions shall not be prevented by a "[1]ack of scientific certainty due to insufficient relevant scientific information and knowledge regarding the extent of the potential adverse effects of a living modified organism on the conservation and sustainable use of biological diversity in the Party of import."116 On the other hand, the Protocol provides that each state's right to regulate the import of LMOs is subject to existing international obligations, which includes those arising under World Trade Organization (WTO) agreements. In fiercely negotiated preambular language, the Protocol provides that the provisions of the Protocol and of WTO agreements are to be "mutually supportive," that the "Protocol shall not be interpreted as implying a change in the rights and obligations of a Party under any existing agreements," while at the
${ }^{114} I d$. art. 10(3)(b).
${ }^{115} I d$. art. 11(4).
${ }^{116} I d$., arts. 10(6) \& 11(8). For other references to precaution, see Biosafety Protocol, pmbl. cl. 4; art. 1; annex III, para. 6. On the precautionary principle, see infra note 150. 
same time such statements are "not intended to subordinate this Protocol to other international agreements." 117 The Protocol thus leaves unclear the relationship between the standards set in the Biosafety Protocol and, to the extent that they may differ, the standards that would otherwise operate under trade agreements. The concern with such import bans is addressed in the next sub-section.

\section{Import Bans on Genetically Modified Products}

Perhaps the most notorious contemporary concern about transnational biotechnology is whether states may ban or restrict imports of genetically modified products for reasons of human health, environmental protection, or consumer preferences. Biotechnology exporting states charge that such bans or restrictions are inconsistent with obligations imposed by the General Agreement on Tariffs and Trade $^{118}$ and associated agreements, including the Agreement on the Application of Sanitary and Phytosanitary Measures ${ }^{119}$ and the Agreement on Technical Barriers to Trade. ${ }^{120}$ The prospects for

${ }^{117}$ Cartegena Protocol, pmbl.

${ }^{118}$ General Agreement on Tariffs and Trade, opened for signature Oct. 30, 1947, 61 Stat. A3, 55 U.N.T.S. 194 [hereinafter GATT]. Relevant GATT obligations include the most-favored nation principle (calling for non-discrimination against imported goods on the basis of their national origin), the national treatment principle (calling for non-discrimination between foreign and domestic goods), and the prohibition on quantitative restrictions for imports or exports.

The GATT has been amended several times, most recently as part of the Uruguay Round, and is now known as GATT 1994. See Final Act Embodying the Results of the Uruguay Round of Multilateral Trade Negotiations, Apr. 15, 1994, WTO Agreement, LEGAL InstRUMENTS - RESUlTs of THE URUgUAy Round vol. 1 (1994), 33 I.L.M. 9 (1994). For U.S. implementing legislation, see Uruguay Round Agreements Act, Pub. L. No. 103-465, 108 Stat. 4809 (1994).

${ }^{119}$ Agreement on the Application of Sanitary and Phytosanitary Measures, Apr. 15, 1994, WTO Agreement, Annex 1A, Legal Instruments - Results of The Uruguay Round vol. 
numerous trade disputes in this area are readily apparent from the current impasse between the United

States and the EU concerning genetically engineered products.

Europeans during the 1990's developed strong concerns about the health effects of imported food, driven largely by the outbreak of "mad cow disease,"121 and those concerns apply equally to genetically modified products. ${ }^{122}$ Although until 1998, the European Union approved the imports of

33 I.L.M. (1994) [hereinafter SPS Agreement]. Under this agreement, a member state has the right to take necessary sanitary measures (i.e., measures protecting human or animal health) or phytosanitary measures (i.e., measures protecting plant life or health) within its territory that affect trade, but only if they are "based on scientific principles, ... and not maintained without sufficient scientific evidence" (art. 2(2)). Moreover, members must "take into account the objective of minimizing negative trade effects" (art. 5(4)) and must "avoid arbitrary or unjustifiable distinctions in the levels it considers to be appropriate in different situations, if such distinctions result in discrimination or a disguised restriction on international trade" (art. 5(5)).

${ }^{120}$ Agreement on Technical Barriers to Trade, Apr. 15, 1994, WTO Agreement, Annex 1A, LEGAL InSTRUMENTS - RESUlTS OF THE URUGUAY Round vol. _ _ ; 33 I.L.M. (1994)

[hereinafter TBT Agreement]. Under this agreement, states agree not to create unnecessary barriers to international trade, or to unjustifiably or arbitrarily discriminate against imports, through their packaging, marketing, and labeling requirements. A key question that often arises is whether a new regulation is substantially equivalent to that imposed by other states in the objective it seeks, even if by different means.

Thus, while the SPS Agreement covers trade barriers to genetically modified products that were enacted for sanitary or phytosanitary purposes, the TBT agreement covers any such barriers that were not enacted for those purposes.

${ }^{121}$ The European Union in 1996 imposed a ban on imports of U.K. beef when it became known that U.K. beef tainted with bovine spongiform encephalopathy (or "mad cow disease") could lead to a variant of the fatal Creutzfeldt-Jakob disease. That ban was lifted in 1999, but the crisis contributed to a loss of European confidence in the safety of foreign foods and the ability of governments to adequately gauge threats to human health. European states have no analogue to the U.S. FDA, although the European Commission has proposed the creation of an all-European food safety agency, consisting of a small advisory body of scientists. See Donald G. McNeil Jr., Europe Plans Advisory Unit on Food Safety, N.Y. Times, Jan. 13, 2000, at A16.

122 The aversion in Europe is not just to foreign grown genetically modified products, but to European grown as well. See, e.g., Rick Weiss, In Europe, Cuisine du Gene Gets a Vehement 
some genetically modified crops under its Directive 90/220, ${ }^{123}$ beginning in March 1998 the European Union suspended any further approvals. Upon the release of a study indicating that pollen from Bt corn was a potential threat to monarch butterflies, ${ }^{124}$ the European Commission on May 20, 1999, froze the EU approval process for Pioneer Hi-bred's genetically modified corn seed, even though EU scientists

Thumbs Down, WAsh. Post, Apr. 24, 1999, at A1.

${ }^{123}$ See Council Directive 90/220 on the Deliberate Release into the Environment of Genetically Modified Organisms, 1990 O.J. (L 117) 15; see also Council Directive 90/219 on Contained Use of Genetically Modified Micro-Organisms, 1990 O.J. (L 117) 1, as amended, Council Directive 98/81, 1998 O.J. (L 330) 13 (relating to the use of microbes in closed systems, such as research centers or laboratories). Under Directive 90/220, to obtain approval for the release of a genetically modified organism into the environment (i.e., before being placed on the market in the EU or made available for incorporation into a product), the manufacturer or importer must submit a notification to the competent authority of the member state where the product will be placed on the market, providing details on the organism, the conditions and environment in which the release will take place, and an assessment of the possible hazards for human health and the environment. The application is then reviewed by scientists and by regulatory officials of the member state. After consultation by the member state with the EU Commission and other member states, a written consent is issued by the EU Commission and affected member states. Although the directive sets minimum standards, each individual member state must enact its own law that implements the directive. If the regulatory officials do not agree that a genetically modified organism product should be approved, the matter is sent to the EU Council of Environment Ministers for approval. It is this final step that was suspended in 1998.

Directive 90/220 establishes the legislative framework for handling living genetically modified products, but does not itself apply to processed or derived products. The directive provides for the development of sectoral legislation concerning novel food types, in the anticipation that such legislation would be adopted as the technology advances. Such sectoral legislation was introduced in 1997, covering foods and food ingredients not previously used for human consumption "to a significant degree within the Community." See Council/Parliament Regulation 258/97, 1997 O.J. (L 43) 1. That directive requires that foods be subjected to a full safety assessment before being placed on the market, as well as compulsory labeling, as noted supra note 96.

The legal basis of the EU to enact environmental legislation arises from Articles 130(r)-(t) of the Single European Act, 1987 O.J. (L 169) (amending the Treaty Establishing the European Economic Community, Mar. 25, 1957, 298 U.N.T.S. 3). It should be noted that Article 130(t) provides that member states may maintain or introduce their own protective measures so long as they are compatible with the EU constituent treaties.

${ }^{124}$ See infra notes $178-80$ and accompanying text. 
had already approved of the seed as posing no threat to human health or the environment. ${ }^{125}$ Then, on June 25, 1999, the EU Council of Environment Ministers in essence ruled out the approval of any new genetically modified organism applications until a revised version of Directive 90/220 was approved by the European Parliament and implemented by the 15 member states. ${ }^{126}$ Consequently, the sixteen genetically modified products already approved for production within and export to the European Union may continue, while those not approved are banned, including where the genetically modified product is mixed with non-modified products. Already, the volume of U.S. corn exports to the European Union has fallen dramatically (by more than 90 percent in 1998). ${ }^{127}$ Further, the European labeling scheme described in the previous sub-section is viewed by some as a non-tariff barrier, designed to protect EU producers from lower-priced, genetically modified U.S. products. ${ }^{128}$

Is the heart of the U.S.-EU dispute old-fashioned protectionism (or anti-Americanism), with European farmers and other producers seeking to maintain traditional forms of production in the face of new and threatening U.S. technologies? Or does the dispute highlight differences in attitudes toward

${ }^{125}$ See Commission to Halt Approval Process for Bt Maize Seed in Light of New Study, 22 Int'l Env't Rep. (BNA) 436 (May 26, 1999). The EU did not, however, take any action against two other Bt corn seeds that had already been approved, those engineered by Novartis and Monsanto.

${ }^{126}$ See EU Environment Ministers Strengthen De Facto Ban on GMOs; WTO Fight Looms, 22 Int'l Env't Rep. (BNA) 567 (July 7, 1999).

127 See Nicole Ballenger et al., Biotechnology Implications for U.S. Corn and Soybean Trade, Agric. Outlook, Apr. 2000, at 24, 24-25, <usda.mannlib.cornell.edu/reports/erssor/economics/ao-bb/2000/ao270.pdf>.

${ }^{128}$ See John Stephen Fredland, Note, Unlabel Their Frankenstein Foods!: Evaluating a U.S. Challenge to the European Commission's Labeling Requirements for Food Products Containing Genetically-Modified Organisms, 33 VAnd. J. Transnat'L L. 183 (2000). 
health and environmental concerns of U.S. and European consumers? ${ }^{129}$ In either event, reconciling these differences may prove difficult under existing international trade agreements and seem likely to lead to a "train wreck" in the not too distant future absent better structures for dealing with them. ${ }^{130}$ An example of the manner in which future disputes will arise over genetically modified products may be seen in the recent dispute over U.S. exports of beef from cattle treated with genetically engineered growth hormones. ${ }^{131}$ On April 29, 1996, the European Union decided to maintain a ban first enacted in the late 1980's on the import of meat derived from cattle treated with certain growth-

${ }^{129}$ Factors found to influence consumer attitudes toward biotechnology include: consumers' philosophies, values, and ethics; their understanding of objective information pertaining to biotechnology and genetic engineering; their trust of specific information sources, such as information received from their government; nationality; and other socio-demographic variables. See Lee, supra note 68, at 63 ("Many consumers have a general, though often ill-defined and difficult to articulate, set of concerns that relate to processes and products which defy easy or intuitive understanding."); Thomas J. Hoban, Consumer Acceptance of Biotechnology: An International Perspective, 15 NATURE BioteCHNOLOGY 232 (1997). Some commentators have noted that Europeans are less urban in their lifestyles and thus more closely tied to the agricultural environment, are more interested in quality than quantity, and are more sensitive to environmental problems caused by one state against another, such as the pollution of the Rhine River. See Martin Kettle, A World of Difference, Wash. Post, Aug. 8, 1999 , at B1.

${ }^{130}$ The timing of such a train wreck is unclear. Trade disputes of the future in this area "are likely to arise out of the unique concentration and strategic outlook of various corporate interests engaged in national and international commerce." See Pepa, supra note 49, at 416. In part to head off such trade disputes, the OECD in 1995 established a working group on harmonization of regulatory oversight in biotechnology. See OECD, Report of the Working Group on Harmonisation of Regulatory Oversight in Biotechnology, OECD Doc. C(2000)86/ADD2 at 6 (May 25, 2000).

${ }^{131}$ The cows themselves are not genetically engineered; rather, they are exposed to a genetically engineered hormone for purposes of accelerating and enhancing their growth. See supra note 26 and accompanying text. 
promoting hormones. ${ }^{132}$ Canada and the United States challenged the import ban as a violation of the European Union's obligations as a member of the WTO. ${ }^{133}$ On August 18,1997 , a WTO dispute panel found that the ban violated provisions of the SPS Agreement and therefore should be lifted. ${ }^{134}$ On January 16, 1998, the WTO Appellate Body affirmed these findings, concluding that the risk assessments that had been performed did not support the ban on imports. ${ }^{135}$

Since the parties could not agree on a deadline for EU compliance, an arbitrator was appointed, who decided that the European Union must comply by May 13, 1999. ${ }^{136}$ The European Union failed to lift the import restrictions by that date, so Canada and the United States requested the WTO Dispute Settlement Body to authorize suspension of the application to the European Union and its member states of Canadian and U.S. tariff concessions and related obligations, in an amount of \$202

${ }^{132}$ See Council Directive 96/22 Concerning the Prohibition on the Use in Stockfarming of Certain Substances Having a Hormonal or Thyrostatic Action and of Beta-Antagoists, and Repealing Directives 81/602/EEC, 88/146/EEC and 88/299EEC, 1996 O.J. (L 125) 3. For background on this dispute, see Implementation of WTO Recommendations Concerning EC-Measures Concerning Meat and Meat Products (Hormones), 64 Fed. Reg. 14,486 (1999).

${ }^{133} 63 \%$ of all cattle and $90 \%$ of feed cattle in the United States are treated with growth hormones. See Elizabeth Olson, \$253 Million Sanctions Sought in Beef Fight With Europe, N.Y. Times, June 4, 1999, at C4.

${ }^{134}$ See EC Measures Concerning Meat and Meat Products (Hormones), WTO Docs. WT/DS26/R/USA \& WT/DS/48/R/CAN (Aug. 18, 1997) at para. 9.1

${ }^{135}$ See EC Measures Concerning Meat and Meat Products (Hormones) (AB-1997-4) WTO Docs. WT/DS26/AB/R \& WT/DS48/AB/R (Jan. 16, 1998); David A. Wirth, International Decisions, 92 Am. J. InT'L L. 755 (1998); Dale E. McNiel, The First Case Under the WTO's Sanitary and Phytosanitary Agreement: The European Union's Hormone Ban, 39 VA. J. INT'L L. 89 (1998).

${ }^{136} \mathrm{See}$ EC Measures Concerning Meat and Meat Products (Hormones) - Arbitration Under 21.3(c) of the Understanding on Rules and Procedures Governing the Settlement of Disputes, WTO Docs. WT/DS26/15 \& WT/DS48/13 (May 29, 1998) at para. 48. 
million for the United States and \$51 million for Canada. ${ }^{137}$ The European Union contested the amount of the U.S. request, so the matter was referred to arbitration by the original dispute resolution panel, which issued a decision on July 12, 1999. ${ }^{138}$ The panel found that the EU's ban on hormone-treated beef resulted in annual U.S. beef export losses of \$116.8 million, and that the United States and Canada were entitled to $\$ 125$ million in sanctions against the European Union. ${ }^{139}$ Therefore, effective July 29, 1999, the United States imposed one-hundred percent tariffs on a range of foodstuffs from the European Union. ${ }^{140}$

The Beef Hormones case not only illustrates the manner in which a dispute over exports of genetically modified products might unfold, but also certain shortcomings in the existing global trade regime for handling disputes over such exports. States and private actors concerned with exports of genetically modified products likely will find that the values embedded in national standards that restrict the imports of genetically modified products are anathema to the trade-oriented values embedded in the GATT regime. ${ }^{141}$ While the GATT has always contained exceptions allowing states considerable

${ }^{137}$ See Olson, supra note 133.

${ }^{138}$ See Elizabeth Olson, U.S. and Canada Get $\$ 125$ Million Ruling on Europe Beef Ban, N.Y. Times, July 13, 1999, at C4.

${ }^{139}$ See European Communities - Measures Concerning Meat and Meat Products (Hormones) - Recourse to Arbitration by the European Communities Under Article 22.6 of the DSU, WTO Docs. WT/DS26/ARB \& WT/DS48/ARB (July 12, 1999).

${ }^{140}$ See Paul Blustein, Europe Hit By Tariffs In Battle Over Beef, WASH. Post, July 20, 1999, at E1.

${ }^{141}$ On the need to strike a balance between trade and non-trade values, see Thomas J. Schoenbaum, Free International Trade and the Protection of the Environment, 86 AM. J. InT'L L. 700 (1992). 
regulatory discretion on matters relating to health and the environment, the widespread perception outside the trade community is that GATT panels have struck a balance strongly favoring trade over non-trade values. ${ }^{142}$ If EU laws or regulations banning imports of genetically modified products are challenged on grounds that they purport to be a "sanitary" measure but are not scientifically justified, ${ }^{143}$

${ }^{142}$ Article XX of the GATT 1994 provides exemptions, including for measures "necessary to protect human, animal, or plant life or health" and for measures "relating to the conservation of exhaustible natural resources if such measures are made effective in conjunction with restrictions on domestic production or consumption." So far, these exceptions have been narrowly construed by GATT dispute resolution panels. See, e.g., United States-Restrictions on Imports of Tuna, GATT, B.I.S.D., 39th Supp. 155 (1993), 30 I.L.M. 1594 (1991); United States-Restrictions on Imports of Tuna, GATT Doc. DS29/AB/R (1994), 33 I.L.M. 839 (1994); United States-Import Prohibition of Certain Shrimp and Shrimp Products, GATT Doc. DS58/AB/R (1998), 38 I.L.M. 118 (1999). The first WTO panel to uphold a trade-restrictive measure under Article XX involved a 1996 French ban on imports of chrysotile (or white) asbestos from Canada. European Communities-Measures Affecting Asbestos and Asbestos-Containing Products, WTO Doc. WT/DS/135/R (2000). Even here, certain environmental groups criticized the panel's reasoning, which found in the first instance that France had violated the national treatment principle because the asbestos was "like"domestically produced, non-toxic substitutes. For environmental groups, asbestos is not "like" a non-toxic substitute, and thus France should not have had to justify its action on the basis of Article XX. See Environmental Groups Criticize WTO Ruling on Asbestos Ban, 17 Int'1 Trade Rep. (BNA) 1432 (Sept. 21, 2000).

${ }^{143}$ See generally Kevin C. Kennedy, Resolving Sanitary and Phytosanitary Disputes in the WTO: Lessons and Future Directions, 55 FoOD \& DRUG L.J. 81 (2000). Alternatively, a challenge might arise under the TBT Agreement. For instance, if a law or regulation requiring labeling of genetically modified products was enacted not to protect human health but, rather, purportedly to inform consumers, it might be challenged on grounds that the law or regulation is really a disguised means of protecting a national industry that is incapable of competing with foreign genetically modified products. If so, the state imposing the ban would need to show that the labeling requirement meets international standards or, if it exceeds them, that those standards "would be an ineffective or inappropriate means for the fulfilment of the legitimate objectives pursued." TBT Agreement, art. 2.42.5 .

A further challenge might arise if a state refuses to allow imports of genetically modified products not just for health, environmental, or consumer reasons but, rather, to prevent potential harm to the state's culture or economy (a matter that arose during the negotiation of the Biosafety Protocol, but that was left unaddressed). 
it seems likely that the challenge would succeed. WTO rules ultimately would place the burden of proof on the EU either to show either that its import restriction was consistent with international standards ${ }^{144}$ or to present scientific evidence that genetically modified products are unsafe. None of the relevant existing international standards would support such an import ban, such as the food safety and pesticide residue standards set by the Codex Alimentarius Commission, ${ }^{145}$ the animal health standards set by the International Office of Epizootics, ${ }^{146}$ the plant health standards set by organizations operating within the

${ }^{144}$ SPS Agreement, art. 3(2).

145 The Codex Commission is a subsidiary body of the FAO and the WHO created in 1962, with currently more than 160 member states. The Codex Alimentarius contains some 200 food commodity standards, 45 codes of practice on hygiene and technology, 700 food additive evaluations, and more than 3,200 limits for pesticide residues. The Codex Commission meets regularly and takes decisions by consensus. Although those decisions serve only as recommendations (they are not binding), the WTO agreements use them as reference standards when considering the permissibility of a national law or regulation. See Roger W. Miller, This Is Codex Alimentarius (1993); Lewis Rosman, Note, Public Participation in International Pesticide Regulation: When the Codex Commission Decides, Who Will Listen? 12 VA. EnvTL. L.J. 329 (1993); see also GA Res. 39/248 (Apr. 16, 1985) (adopting guidelines for consumer protection). A Codex committee on food labeling is current working on a standard for labeling proposals for foods derived from biotechnology. See Codex Committee on Food Labeling to Spend Year Developing GMO Proposals, 17 Int'1 Trade Rep. (BNA) 827 (2000).

NAFTA states are also expected to use international standards, such as the Codex standards, as a guideline when considering compatibility of a national law or regulation under the NAFTA. See North American Free Trade Agreement, Can.-U.S.-Mex., entered into force Jan. 1, 1994, arts. 712713, 32 I.L.M. 289, 368-82.

${ }^{146}$ See International Agreement for the Creation at Paris of an International Office for Epizootics, Jan. 25, 1924, 26 U.S.T. 1840, 57 L.N.T.S. 135. The Office was established to track and study animal diseases and harmonize international regulation related thereto. Like the standards set by the Codex, the standards set by the Office are supposed to foster international harmonization in sanitary measures, so as to prevent their use as unjustified barriers to trade. 
framework of the International Plant Protection Convention (IPPC),${ }^{147}$ or other international

standards. ${ }^{148}$. An EU measure in excess of such international standards must be scientifically justified,

meaning that, after analyzing available scientific data, the EU must determine that the international

standard is insufficient to attain its "appropriate level of sanitary or phytosanitary protection."149 Until

${ }^{147}$ See International Plant Protection Convention (IPPC), Dec. 6, 1951, 150 U.N.T.S. 67

(revised Nov. 28, 1979). Administered by the FAO, the IPPC was established to address international control of pests and diseases affecting plants and products generated from plants. The IPPC calls for phytosanitary measures to be based on a pest risk analysis, which covers both economic and environmental factors, including possible detrimental effects on natural vegetation. The IPPC also provides for the prohibition or restriction of the transboundary movement of biological control agents and other organisms of phytosanitary concern. Thus, any genetically modified organism that could be considered a pest of plants falls within the scope of the IPPC.

${ }^{148}$ An influential standard-setting entity is the International Organization for Standardization (ISO). The ISO - a non-governmental organization established in 1947 and based in Geneva - is a worldwide federation of the national standards bodies from some 130 countries. The mission of ISO is to promote the development of standardization and related activities in the world with a view to facilitating the international exchange of goods and services, and to developing cooperation in the spheres of intellectual, scientific, technological and economic activity. ISO's work results in transnational agreements within the business community, which are published as "International Standards." For instance, tens of thousands of businesses are implementing "ISO 9000," which provides a framework for quality management and quality assurance. The "ISO 14000" series provides a similar framework for environmental management. See generally W.M. von ZHAREN, ISO 14000: UndERSTANDING THE EnVIRonmental Standards (1996); Naomi Roht-Arriaza, Shifting the Point of Regulation: The International Organization for Standardization and Global Lawmaking on Trade and the Environment, 22 ECOLOGY L.Q. 479 (1995). For the ISO's Internet site, see <http://www.iso.ch>. On the emergence of standards in the field of international environmental law, see PETER H. SAND, Transnational EnVironmental Law:Lessons in Global Change 11-41 (1999).

${ }^{149}$ SPS Agreement, art. 3(3), note. Where relevant scientific evidence is insufficient, a member may provisionally adopt sanitary or physanitary measures, but must seek and review the necessary information within a reasonable period of time. Id., art. 5(7). See John J. Barceló III, Product Standards to Protect the Local Environment - the GATT and the Uruguay Round Sanitary and Phytosanitary Agreement, 27 CoRnell InT'L L.J. 755 (1994). The decision in the Beef Hormones case confirms that if the EU has an adequate scientific assessment showing possible risk to human health or the environment, restricting imports will not be regarded as a violation of WTO agreements. See generally Wybe Th. Douma \& M. Jacobs, The Beef Hormones Dispute and the Use of 
such time as states reach a consensus on the risks of genetically modified products, EU states have no scientific basis for arguing that genetically modified products are unsafe. Rather, they are left arguing on the basis of consumer preferences or on more heightened risk standards that may exist in customary international law or general principles of law, ${ }^{150}$ which are not adequate independent grounds under WTO rules. ${ }^{151}$ In the end, some states, and consumer and environmental groups, will see themselves as dominated by an institution and rules that is intolerant to their more risk-adverse concerns. More

National Standards Under WTO Law, 8 EuR. ENVTL. L. REV. 137 (1999).

${ }^{150}$ For instance, various formulations of the precautionary "principle" or "approach" may be found in other international instruments, such as the Rio Declaration on Environment and Development, U.N. Conference on Environment and Development, Principle 15, U.N. Doc. A/CONF.151/5/Rev. 1 (1992), 31 I.L.M. 876 (1992), although there appears no universally agreed formulation as to its import. See Interpreting the Precautionary Principle (Timothy O'Riordan \& James Cameron eds., 1994); James Cameron \& Juli Abouchar, The Precautionary Principle: A Fundamental Principle of Law and Policy for the Protection of the Global Environment, 14 B.C. INT'L \& Comp. L. Rev. 1 (1991); Frank B. Cross, Paradoxical Perils of the Precautionary Principle, 53 Wash. \& LeE L. ReV. 851 (1996); Pascale Martin-Bidou, Le principe de précaution en droit international de l'environnement, 103 REvUE GÉNÉRALE DE DROIT InTERnATIONAL Public 631 (1999). On its application in the WTO and NAFTA, see David A. Wirth, The Role of Science in the Uruguay Round and NAFTA Trade Disciplines, 27 CORNELL INT'L L.J. 817, 840 (1994).

To argue both sides of such a challenge, one might try to extract a variety of relevant "principles" from existing international agreements. See Peter Drahos, Genetically Modified Organisms and Biosafety: The Global Regulatory Issues, BIO-SCIENCE L. REV . 40, 47-48 (1999/2000) (citing to "principles" of "risk assessment," "information exchange," "familiarity or substantial equivalence," "non-discrimination," "harmonization," "private property," "informed consent," "benefit sharing," and "labeling").

${ }^{151}$ For instance, in the Beef Hormones case, the appellate body affirmed the panel's conclusion that the SPS Agreement already incorporated the precautionary principle, such that it could not be raised by the European Union as an independent legal argument separate from the SPS Agreement. See Appellate Report, supra note 135, at para. 253(c); Panel Report, supra note 134, at para. 8.249. The appellate body found that the precautionary principle is reflected in some provisions of the SPS Agreement, but that "the principle has not been written into the SPS Agreement as a ground for justifying SPS measures that are otherwise inconsistent with the obligations of Members set out in particular provisions of the Agreement." Appellate Report, supra note 135, at para. 124. 
broadly, it seems that the post-Cold War rush towards economic globalism, paired with the 1994 expansion of trade agreements into non-traditional areas such as intellectual property; services, investment, has exceeded the means by which global politics can keep pace. As such. various state and non-state actors perceive that the excesses of global trade are unchecked, thus leading to demands for greater transparency and inclusion in WTO processes. Absent new means to defuse such perceptions, they might ultimately destablilize the trade regime itself. Efforts by the WTO to launch a "millennium" round of trade talks in Seattle collapsed in December 1999 amidst concerns of this nature, even though one of the objectives of the Clinton Administration was to make the WTO more open and responsive to environmental, labor, and consumer concerns..$^{152}$

Further, the global trade regime may have difficulties coping with export bans on genetically modified products due to conflicts with norms embedded in other treaty instruments. For instance, as noted at the end of the last sub-section, the inter-relationship between the Biosafety Protocol and the GATT and its associated instruments is unclear. If the United States challenged an EU import ban on genetically modified products, the EU might respond that its import ban is based on a risk assessment that conforms with the Biosafety Protocol. A WTO panel confronted such a case might regard the

${ }^{152}$ See Sean D. Murphy, Contemporary Practice of the United States Relating to International Law, 93 AM. J. INT'L L. 491 (1999). The collapse was presaged by a week of protests in Seattle against the WTO, principally by environmental, labor, consumer, and public interest groups, interspersed with riots by various factions. Environmental groups accused the WTO of ignoring the environmental impact of its decisions, such as the decision calling upon the United States to amend its import ban on shrimp caught with nets harmful to sea turtles. See Sean D. Murphy, Contemporary Practice of the United States Relating to International Law, 94 AM. J. INT'L L. 375 (2000). For a somewhat polemical but nonetheless engaging treatment of the environmental, labor, and consumer concerns with the WTO, see Lori Wallach \& Michelle Sforza, Whose Trade Organization?: Corporate Globalization and the Erosion of Democracy (1999). 
Protocol as essentially a global standard that LMOs are particularly dangerous, that scientific certainty of potentially adverse effects from LMOs is not necessary, and that therefore states have great discretion in erecting national trade restrictions preventing or minimizing imports of LMOs. However, the panel would have to confront the fact that the United States is not a party to the Biosafety Protocol in considering whether the standards it sets are appropriate for the dispute. ${ }^{153}$ Further, in assessing the exact risk assessment undertaken to support the EU import restriction, the panel might find that the standard of risk assessment used under the Protocol differs from that called for under a different treaty regime, such as the IPPC (to which the United States is a party). ${ }^{154}$ The thrust of the risk assessment under the IPPC is relatively narrowly in that it is designed to ensure the protection of plants, while the thrust of the risk assessment under the Biosafety Protocol seems designed to protect biological diversity generally.

No doubt the contours of these varied treaty obligations will only be developed over time

${ }^{153}$ One might argue that the standard set in a global environmental treaty constitutes a customary rule of international law that is properly used to interpret the GATT even if one of the states is a non-party to the environmental treaty. See Philippe Sands, Sustainable Development: Treaty, Custom, and the Cross-Fertilization of International Law, in INTERNATIONAL LAW AND Sustainable Development 39 (Alan Boyle \& David Freestone eds., 1999). On the other hand, traditional interpretation of customary international law allows for a state to claim the status of a persistent objector to an emerging customary rule, such that a WTO panel would need to decide whether failing to ratify the Protocol constitutes an implicit rejection of the emerging standard. Compare Ian Brownlie, Principles of Public International Law 10 (4th ed. 1990) (noting the strength of the persistent objector rule), with Jonathan I. Charney, The Persistent Objector Rule and the Development of Customary International Law, 1985 BRIT . Y.B. INT'L L. 1 (doubting the efficacy of the rule). In the context of a WTO dispute, however, it is not clear why the existence of an international standard need turn on showing the existence of a customary rule of international law, nor adhere to its modern or traditional rules of formation.

${ }^{154}$ See John H. Barton, Biotechnology, the Environment, and International Agricultural Trade, 9 Geo. InT'L ENVTL. L. REV. 95, 113-14 (1996). 
through repeated interactions among states (and other actors) as particular cases arise, with considerable cross-fertilization among a panoply of existing regulatory regimes. The WTO dispute resolution process can usefully contribute to this development, but there are reasons to doubt whether it alone can handle the task. One might debate whether panel decisions handed down on a case-by-case basis are suitable for filling in the gaps of WTO agreements. ${ }^{155}$ Yet the problems noted above go beyond even such gap-filling; they relate to conflicts with agreements outside the traditional realm of the WTO, and involving constituencies who do not view the WTO as the appropriate body for resolving the conflicts. Moreover, even states and other actors favoring trade in genetically modified products may find the WTO process unsatisfactory given the difficulty of even successful complainants (at least in the Beef Hormones case) in obtaining compliance from the importing states. If so, such states might begin resorting to aggressive unilateral sanctions, which may coerce compliance with WTO rules, or may just make matters worse. ${ }^{156}$

155 Compare John H. Jackson, The Jurisprudence of GATT And the WTO 187 (2000) (doubting the gap-filling ability of the dispute resolution process), with Raj Bhala, The Precedent Setters: De Facto Stare Decisis in WTO Adjudication, 9 Fla. ST. U.L. Rev. 1 (1999) (noting the emergence of a procedural and substantive common law from WTO adjudication).

${ }^{156}$ Under U.S. Trade Act of $1974 \$ 301$, 19 U.S.C. $\$ 2411$ (1994), the U.S. Trade Representative can investigate alleged unjustifiable or unreasonable trade practices of other states and impose unilateral sanctions if the allegations are correct. The EU challenged the existence of this "Section 301" procedure as a violation of Articles 3, 21, 22, and 23 of the WTO Dispute Settlement Understanding. See United States-Sections 301-310 of the Trade Act of 1974, WTO Doc. WT/DS152/R (Dec. 22, 1999). The panel found that the language of Section 301 on its face is inconsistent with the United States' WTO obligations. However, the panel concluded that Section 301 provides USTR with adequate discretion to comply with WTO rules in all cases. Further, assurances about how that discretion will be exercised can be found in the statements by the United States to the panel, as well as in the U.S. adherence to WTO instruments. In particular, the panel noted the statements made in the Uruguay Round Agreements Act Statement of Administrative Action, which was submitted by the President to the Congress on September 27, 1988, and approved as part of the 
A further problem for the WTO regime is its tendency to view trade problems as bilateral in nature and as soluble through dispute proceedings controlled by states. Yet potential trade bans relating to genetically modified products have wide-ranging ramifications for different groups of states and involving trade in a variety of directions and affecting a variety of actors. Thus, the potential for trade disruptions in this area is by no means limited to trade between the United States and Europe. Monsanto's effort to sell genetically modified, herbicide-resistant soy seeds through its subsidiary in Brazil were blocked due to protests from environmental groups. ${ }^{157}$ Major Japanese and Mexican companies have announced that they will no longer import genetically modified grain for their products (such as beer and corn tortillas). ${ }^{158}$ Public protests have occurred around the world, including in places as diverse as New Zealand and South Korea. ${ }^{159}$ This backlash, in turn, has discouraged some U.S. farmers from investing further in genetically modified crops and to consider ways of segregating genetically modified crops from conventional crops. ${ }^{160}$ Yet the backlash is not uniform among citizens in different states. Environics, a Toronto-based public environmental policy firm, surveyed citizen reactions in 25 developed and developing states and found favorable attitudes toward genetically modified products in several of them, at least when the questions concerned the use of biotechnology to

Uruguay Round Agreements Act. See 19 U.S.C. §3511(a) (1994).

${ }^{157}$ See Brazil: Altered Crops Approved, N.Y. Times, May 19, 1999, at A8.

${ }^{158}$ See Weiss, supra note 99; Melody Petersen, New Trade Threat For U.S. Farmers, N.Y. Times, Aug. 29, 1999, at 1.

${ }^{159}$ See Weiss, supra note 122, at A11.

${ }^{160}$ See Weiss, supra note 99; William Claiborne, Biotech Crops Spur Warning, WASH. Post, Nov. 24, 1999, at A11. 
grow pest-resistant crops that require less farm chemicals or to develop new medicines and treatments for human diseases. ${ }^{161}$

Indeed, there is an important link between the concern with trade bans and the concern discussed above regarding equitable sharing of the benefits of biotechnology applications with the developing world. If a backlash largely among developed states leads to severe restrictions on trade of genetically modified products, it will affect developing states even if, in their view, the risks are worth the benefits. As the Nigerian Minister of Agricultural and Rule Development has noted:

It is possible to kill someone with kindness, literally. That could be the result of the wellmeaning but extremely misguided attempts by European and North American groups that are advising Africans to be wary of agricultural biotechnology. They claim to have the environment and public health at the core of their opposition, but scientific evidence disproves their claims that enhanced crops are anything but safe. If we take their alarmist warnings to heart, millions of Africans will suffer and possibly die.

To deny desperate, hungry people the means to control their futures by presuming to know what is best for them is not only paternalistic but morally wrong. Certainly, those with

${ }^{161}$ See Biotech: Yes or No?, Wash. Post, Oct. 16, 1999, at A19. 
fertile lands and an abundance of food have every right to decide how they would like to grow their crops and process their foods. Organic farming, sophisticated methods of distributing food and other approaches are well and good for those who can afford to experiment. Starving people do not have this luxury. They want food and nourishment, not lectures . . . ${ }^{162}$

At the same time, one can imagine reasons why developing states might ultimately resist imports of genetically modified products, for reasons having nothing to do with human health or the environment. For instance, there were severely adverse consequences for the developing world from the so-called "green revolution" of past decades, ${ }^{163}$ involving rapid alterations in farming practice and profitability due to the advent of new crop varieties, pesticides, and herbicides that increased crop yields. A biotechnology revolution for developing states may well bring more of the same, running more small farmers out of business and shifting rural populations to already crowded cities. If so, there may be pressures upon those states to restrict imports of genetically engineered products.

The trade issue also is not limited to exports from developed states to the developing world. Advances in biotechnology may increase the ability of developing states to generate products for

${ }^{162}$ Hassan Adamu, Editorial, We'll Feed Our People As We See Fit, WAsH. Post, Sept. 11, 2000, at A23; see also Gregg Easterbrook, Editorial, Food for the Future, N.Y. TimES, Nov. 19, 1999, at A31; Paarlberg, supra note 57, at 30 ("[T]he most important stakeholders in the fight over GM foods have not been heard. It is among poor farmers and poor consumers in developing countries that the potential gains from this technology are most significant.").

163 "Green revolution" refers to the large-scale, transformative, productivity-enhancing developments in world agriculture in recent decades, largely due to the development of high-yield hybrid crops, commercial fertilizers, and herbicides and pesticides to control weeds and insects. 
export, an outcome that would be inhibited by trade bans. ${ }^{164}$ Yet, even here, there may be perils for the developing world from the biotechnology revolution. ${ }^{165}$ The primary concern of developing states regarding biotechnology is probably not related to human health or the environment but, rather, the potential trade shifts due to the development of substitute goods and processes for those in which developing states currently have a comparative advantage. For example, the development by the United States of high-fructose corn syrup in the 1970s led to a radical decline in U.S. sugar imports from developing states. ${ }^{166}$

Thus, the law and processes available in the context of the WTO are useful, but may fall short in providing a means for comprehensively addressing the range of concerns that arise in the area of transnational biotechnology. By its nature, the WTO has trouble appealing to non-trade constituencies, and the transparency and state-oriented nature of its processes for dispute resolution and for amendment remain problematic. The ability of developing states to participate meaningfully in these processes is uncertain. The potential for conflicts with other treaty regimes is significant. And perhaps most important, the increasing complexity of trade concerns - involving various blocs of states and non-

${ }^{164}$ See, e.g., Per-Pinstrup Andersen, Editorial, Biotech and the Poor, WAsh. Post, Oct. 27, 1999, at A31 ("[I]f moratoriums on biotech research became widespread, developing countries would not be able to export genetically modified food and agricultural goods to Europe and other countries where they are prohibited.”).

165 See Mae-Wan Ho, Genetic Engineering-Dream or Nightmare? 125-26 (1998); Phil Gates, The Environmental Impact of Genetically Engineered Crops, 13 BIOTECHNOLOGY \& GENETIC ENGINEERING REviEws 181, 188-89 (1996) (noting historical precedents for the disruption of developing state economies when traditional production centers were moved to developed states, such as the decline of the indigo industry in India after the development of synthetic dye substitutes).

${ }^{166}$ See Lee, supra note 68, at 58-59. 
state actors and trade flows in various directions capable of provoking considerable fear and insecurity - calls for fresh thinking about transnational structures for incorporating new values into the global trade regime.

\section{Liability for Damage by Genetically Modified Imports}

Implicit in the concerns previously mentioned about biotechnology is the possibility that harm will occur from a genetically modified product to human health or the environment. When such harm occurs, should someone be held liable and, if so, who and for what damage? For instance, a U.S. company engineered soybeans to be more nutritious by using genes from Brazilian nuts, but discovered prior to marketing that the soybeans were capable of triggering allergic reactions in humans ${ }^{167}$ Had the product been marketed nationally, what liability would ensue and for whom?

The question becomes even more complex when genetically modified products are marketed worldwide. Although the science of biotechnology is an astounding testament to the creative intelligence of humanity, there remains an enormous amount of the science that is unknown. Among this is "gene expression," or how a particular modified gene in fact will operate when exposed to different environmental factors. There is an unquantifiable risk of adverse secondary effects on eco-systems, including damage to non-targeted species, which in turn can cascade to other species. For instance, scientists at Oregon State University engineered a soil bacterium to produce ethanol, so that the

${ }^{167}$ See J.A. Nordlee et al., Identification of a Brazil-Nut Allergen in Transgenic Soybeans, 334 NEw ENG. J. MED. 726 (1996). 
residues of crops grown in the soil could be used to produce fuel. However, the scientists discovered that the bacterium killed off fungi that are important for plant nutrient intake, such that if the bacterium had been released and spread widely, it might have severely harmed plant life. ${ }^{168}$ While the risk of gene expression might be handled by careful assessment of the eco-system of a state (or region of a state) where the genetically modified product is to be released, the ability to manage such risk increases considerably when organisms are exported globally to numerous different eco-systems. ${ }^{169}$

Moreover, there is a risk of "gene flow," whereby the genetically manipulated genes of one organism (such as a plant) are inadvertently transferred (such as through pollen) to another plant. Gene flow typically occurs only between closely-related species. Studies in one state showing that gene flow is unlikely for a particular plant may not be accurate for another state. For instance, while the likelihood of gene flow in the United States of a genetically manipulated potato may be low since the potato is not indigenous to North America, the likelihood of gene flow in South America may be much higher, since that is the environment in which the potato originated and evolved (many crops have a "center of diversity" where they originally developed or have grown for centuries). ${ }^{170}$ In other words, the

\section{See Chris Bright, Life Out of Bounds: Bioinvasion in a Borderless World 61} (1998).

${ }^{169}$ See James M. Tiedje et al., The Planned Introduction of Genetically Engineered Organisms: Ecological Considerations and Recommendations, 70 ECOLOGY 298, 311 (1989) ("Because the potential hazards of engineered organisms are often environment-dependent, and ecosystems and biotas vary geographically and climatically, an organism that is safe in one country (or one state) is not necessarily safe in another.").

${ }^{170}$ In fact, the major crop plants of cotton, corn, soybean, and wheat have no wild relatives in the United States. The OECD has noted:

This significantly influences concern in relation to "escape" of a newly released genetic entity. In 
likelihood of the gene of the genetically manipulated potato transferring to some other organism may be higher in South America, since there are other, potato-like plants in South America. ${ }^{171}$ Why should that matter? In theory, an insect resistant gene in a potato plant in Peru could transfer to some other potatolike plant that is actually an undesirable weed, resulting in massive spreading of that weed due to the inability of insects to feed upon it.

National authorities are currently grappling with how to handle liability for damage by genetically modified products. ${ }^{172}$ Over the course of the next several years, the parties to the Biodiversity Convention intend to pursue a "process with respect to the elaboration of international rules and procedures in the field of liability and redress for damage resulting from the transboundary

contrast, Spain is a major centre of natural genetic diversity, with 8,000 plant species of which 3,000 are endemic and with many crop relatives. For Spain, consideration of interpollination with wild species will be a major factor. For Norway, with strong economic dependence on native trees, it would be important to ensure that introduction of traits into related tree species does not adversely influence the long-term reliability of an important natural resource.

OECD, Field Releases of Transgenic Plants, 1986-92: An Analysis 24 (1993).

${ }^{171}$ See Gates, supra note 165, at 188.

172 See Richard A. Repp, Comment, Biotech Pollution: Assessing Liability for Genetically Modified Crop Production and Genetic Drift, 36 IDAHo L. Rev. 585 (2000); Celeste Marie Steen, Note, FIFRA's Preemption of Common Law Tort Actions Involving Genetically Engineered Pesticides, 38 ArIz. L. ReV. 763 (1996); Note, Designer Genes that Don't Fit: A Tort Regime for Commercial Releases of Genetic Engineering Products, 100 HARV. L. REV. 1086 (1987). The European Parliament on February 11, 1999, passed new restrictions on the import of genetically modified organisms, including a demand that exporters take on legal liability for environment-damaging genetic accidents. The legislation must be passed by the European Council of Ministers before it becomes law. For a discussion of European liability regimes, as well as an argument that biotechnologyspecific liability rules are not necessary, see Lucas Bergkamp, Allocating Unknown Risk: Liability for Environmental Damages Caused by Deliberately Released Genetically Modified Organisms (2000) (unpublished manuscript on file with the author). 
movements of living modified organisms." ${ }^{, 173}$ Like the Biosafety Protocol itself, this process will be limited to adverse effects caused by LMOs. While establishment of rules and procedures through such a process would be a welcome development, the prospect for successful conclusion of an international instrument on liability are slight without widespread support not just from biotechnology-importing states, but from biotechnology exporting states and their companies as well. ${ }^{174}$ Many international agreements contain provisions calling for the development of liability regimes, but so far few regimes have been developed. ${ }^{175}$ The regimes that have developed, such as in the context of nuclear energy, have limited numbers of states as parties. ${ }^{176}$

\section{${ }^{173}$ Biosafety Protocol, art. 25.}

${ }^{174}$ For a discussion of potential corporate transnational liability, see Stephen Kelly Lewis, Comment, "Attack of the Killer Tomatoes?" Corporate Liability for the International Propagation of Genetically Altered Agricultural Products, 10 TRANSNAT'L LAW . 153 (1997).

${ }^{175}$ For a recent study of liability for environmental damage under international law by a respected private association of international law scholars, see Institut de Droit International Resolution on Responsibility and Liability Under International Law for Environmental Damages, Sept. 4, 1997, 67:1 Annuaire de L'Institut de Droit InTERnational 347 (1997); see also Christian von Bar, Environmental Damage in Private International Law, 268 ReCUEIL DES CouRs (Hague ACAdemy of International Law) 291 (1997); Rüdiger Wolfrum, Means of Ensuring Compliance with and Enforcement of International Environmental Law, 272 RECUEIL DES COURS (Hague Academy of International Law) 77-100 (1998); Sean D. Murphy, Prospective Liability Regimes for the Transboundary Movement of Hazardous Wastes, 88 AM . J. INT'L L. 24 (1994).

176 The nuclear liability regime developed by the OECD currently has 14 parties and does not include the United States. Convention on Third Party Liability in the Field of Nuclear Energy, July 29, 1960, 956 U.N.T.S. 251, reprinted in 55 AM. J. INT'L L. 1082 (1960) (subsequently amended). The nuclear liability regime developed by the International Atomic Energy Agency has 14 parties (several of which have no nuclear installations) and does not include the United States. Convention on Civil Liability for Nuclear Damage, May 21, 1963, 1063 U.N.T.S. 265, reprinted in 2 I.L.M. 727 (subsequently amended). The two regimes were linked in the Joint Protocol Relating to the Application of the Vienna Convention and the Paris Convention, Sept. 21, 1988, reprinted in 42 NuClEAR L. 
There are multiple difficulties unrelated to biotechnology in developing such a legal regime, covering both procedural issues (such as which courts have jurisdiction over the claims and the parties, which parties have standing to bring the claims, and whether judgments are enforceable in another nation's courts) and substantive issues (such as the burden of proof and limitations on liability). But there are additional difficulties linked with some of the concerns discussed in prior sub-sections. If a developing state is entitled to joint benefits when a biotechnology company develops a product using the genetic resources located in the state, arguably liability should be joint if the product causes damage. To the extent equitable concerns argue in favor of distributing biotechnology applications on a lowcost/no-cost basis, arguably a biotechnology company should not be liable or should be minimally liable for ensuing damage. If fully liable, presumably the biotechnology companies will be inhibited from engaging in altruistic behavior. Moreover, high exposure to liability may inhibit biotechnology companies from marketing their products in states where profit margins are low, such as in Africa. Further, if the risk of damage is known, and fully disclosed to an importing state, but the state decides that the risk is far outweighed by the potential benefits to its economy and people, presumably that is relevant in considering the liability of the biotechnology company. And if a state refuses to grant intellectual property protection to a genetically modified product, so that it can be freely reproduced within the state, but then damage ensues, presumably that too is relevant to any liability of the patent holder. One must ask whether resolving these complex issues is this best done through a global treaty/protocol, through national legislation, or through private contracting? Perhaps the only means for successfully

BuLL. 56 (1988). 
navigating these issues is to devise new means for achieving a high level of common understanding and consensus among the relevant actors in the field of transnational biotechnology.

\section{Liability for Extraterritorial Damage by Genetically Modified Products}

Once products are genetically modified, they may have adverse effects on the human health or environment of adjacent states, even if wholly produced and consumed in one state. Concerns about the emergence of "superweeds" or "superbugs" in the national setting are equally applicable in the transnational setting, since weeds and bugs do not respect national boundaries. To the extent that genetically modified animals and plants are released into national environments, it is inevitable that they will turn up in the territory of adjacent states. Thus, one can imagine that Brazil, which to date has resisted use of genetically modified crops, could adversely affected by the use of genetically modified crops in Argentina, which shares a lengthy border with Brazil. Even states distant from the user of genetically modified products could be affected. For instance, salmon have been genetically engineered in the laboratory to be about twice as large as regular salmon; once approved for widespread breeding in the United States or Canada, some scientists fear that engineered salmon will escape from their net pens causing adverse effects on wild salmon, ${ }^{177}$ thereby affecting all salmon-harvesting states.

177 See Carol Kaesuk Yoon, Altered Salmon Leading Way To Dinner Plates, but Rules Lag, N.Y. Times, May 1, 2000, at A1. The adverse effects on wild species could occur if wild females are attracted to the larger, engineered males but, due to genetic differences, are unable to produce viable off-spring. See William M. Muir \& Richard D. Howard, Possible Ecological Risks of Transgenic Organism Release When Transgenes Affect Mating Success: Sexual Selection and the Trojan Gene Hypothesis, 96 Proc. NA T'L ACAD. SCI. 13,853 (1999) (studying mating and 
Genetically modified products might have even more subtle effects on adjacent states.

Laboratory studies conducted at Cornell University indicate that corn crops in the United States genetically modified to contain Bt might indirectly kill monarch butterflies that migrate from Mexico through the United States to Canada and back. ${ }^{178}$ The corn, which is used in about one-fourth of all U.S. corn crops, has been modified to exude a Bt that kills corn-boring caterpillars. The problem arises if pollen from the corn drifts by wind onto milkweed plants adjacent to the cornfields. Monarch butterflies migrating from their winter breeding grounds in Mexico through the primary corn-producing areas in the U.S. Midwest (Iowa, Illinois, Indiana, and Ohio), lay their eggs on the milkweed; if the larvae hatch and begin feeding on the milkweed, the poisonous pollen could kill them. From these laboratory studies, we do not yet know whether monarch populations in their natural habitat are actually affected by the toxic pollen, ${ }^{179}$ yet similar results may occur in places where endangered species are

survivorship in normal and genetically engineered versions of a fish known as a medaka).

178 See John E. Losey et al., Transgenic Pollen Harms Monarch Larvae, NATuRE, May 20, 1999, at 214; but see C.L. Wraight et al., Absence of Toxicity of Bacillus Thuringiensis Pollen to Black Swallowtails Under Field Conditions, 97 Proc. NA T'L ACAD. Scr. 7,700 (2000) (field study finding no adverse affects on butterflies from genetically modified corn pollen); see also Marc Kaufman, 2nd Study Links Gene-Altered Corn, Butterfly Deaths, WAsh. Post, Aug. 22, 2000, at A2. For similar adverse affects of Bt on bees, see M.W. See Ho et al., The Biotechnology Bubble, 28:3 ECOLOGIST 146-153 (1998).

${ }^{179}$ See Carol Kaesuk Yoon, No Consensus On the Effects Of Altered Corn On Butterflies, N.Y. Times, Nov. 4, 1999, at A15; Rick Weiss, Gene-Altered Corn's Impact Reassessed, WAsH. Post, Nov. 3, 1999, at A3. Monsanto, the producer of Bt corn, notes that the "natural habitat for milkweed is prairies, fields, and roadsides, not the middle of full grown and pollinating corn fields" and thus "the exposure of milkweed to corn pollen is very low." See Monsanto Press Release on Bt Corn: Environmental Safety And A Recent Report On The Monarch Butterfly (May 19, 1999), <http://www.monsanto.com/monsant/mediacenter/background/99may19_Monarch.html>. 
closely associated with agricultural landscapes, such as Europe. ${ }^{180}$ Thus, while it is not clear to what extent monarch butterflies are being affected by Bt corn, the possibility of such transboundary harm is clear.

There are general principles of international law, including international environmental law that, while recognizing the rights of states to exploit their national resources, call upon states not to allow their territory to be used for activities that cause damage to the environment of other states. ${ }^{181}$ While these principles are useful in framing discussions in any given area of international intercourse, standing alone they are not sufficient for addressing complex issues of state responsibility for transnational damage from biotechnology applications. The International Law Commission has for years been trying to elucidate in greater detail the rules to apply when states cause transboundary damage, either in

${ }^{180}$ See Weiss, supra note 61 (quoting a University of Minnesota insect ecologist).

${ }^{181}$ See, e.g., Principle 21 of the 1972 Stockholm Declaration of the United Nations Conference on the Human Environment, U.N. Doc. A/CONF.48/14 (1972), reprinted in 11 I.L.M. 1416 (1972). Principle 21 provides:

States have, in accordance with the Charter of the United Nations and the principles of international law, the sovereign right to exploit their own resources pursuant to their own environmental policies, and the responsibility to ensure that activities within their jurisdiction or control do not cause damage to the environment of other States or of areas beyond the limits of national jurisdiction.

See also 1992 Rio de Janeiro Declaration on Environment and Development, U.N. Doc. A/CONF.151/5 (1992), Principle 2 (which adds "and developmental" before "policies"). This customary rule emerged from various strands of international law, including: the doctrine of sic utere tuo ut alienum non laedas (one must use his own so as not to injure others); the doctrine of abuse of rights; the principle of good neighborliness; the decision of the International Court of Justice in the Corfu Channel Case, 1949 ICJ REP. 4, 22 (Merits), which notes "every State's obligation not to knowingly allow its territory to be used for acts contrary to the rights of other states"; and, of course, the well-known Trail Smelter Case, 3 R.I.A.A. 1911 (1963-66). 
situations where a wrongful act has occurred or where no wrongful act has occurred. So far, those efforts have not borne fruit. ${ }^{182}$ Moreover, rather than building liability regimes for compensation ex post facto, many believe that greater emphasis should be placed on regulating the emission of pollutants $a b$ initio before they cause damage to adjacent states, as done in most international environmental agreements.

At present, a similar effort in the field of transnational biotechnology is premature, given the lack of any strong scientific evidence of transboundary harm to one state of genetically modified products wholly produced and consumed in an adjacent state. Yet, as was the case for the prior sub-section, to the extent that such evidence emerges, there may be calls for the development of a legal regime capable of identifying and addressing the origins of such harm and facilitating the payment of compensation. If so, consensus among a wide range of potentially affected state and non-state actors will be critical in developing such a regime.

Long-term Decline in Global Biological Diversity

The fruits of biotechnology are possible because of the wide diversity of the global gene pool.

${ }^{182}$ See Ninth Report on International Liability for Injurious Consequences Arising Out of Acts Not Prohibited by International Law, II:1 Y.B. InT'L L. Comm'N 187 (1993); Alan Boyle, Codification of International Environmental Law and the International Law Commission: Injurious Consequences Revisited, in InTERnational Law And Sustainable Development, supra note 153, at 61, 84 ("It is easier to identify what the ILC has not contributed to the evolution of international environmental law than what it has."). For information on the ILC and its work, see $<$ http://www.un.org/law/ilc/index.htm>. 
This global biological diversity is already declining at an alarming rate; indeed, agriculture today relies on just a handful of crops (corn, rice, rye, wheat) concentrated in a relatively small number of varieties. ${ }^{183}$ In some ways, the biotechnology revolution may slow down the decline in biological diversity. Insecticides currently sprayed on crops kill many non-targeted, beneficial species. If new biotechnologies lead to decreased use of such insecticides, those species will be better off. Further, the single largest threat to biological diversity stems from the conversion of native lands to agricultural use in order to feed increasing populations. ${ }^{184}$ Most genetically modified products likely to affect biological diversity are new crop cultivars designed to sustain or increase yields without expanding the size of croplands.

The biotechnology revolution, however, may also accelerate the decline of biological diversity. When large companies such as Monsanto export seeds of a genetically modified plant, such as Bt corn, the idea is that farmers in the importing state will stop using their traditional crop varieties (referred to as landraces) in favor of Monsanto's seeds. In so doing, those native varieties are lost, and along with them what may be the sole repositories of certain genes. ${ }^{185}$ Further, the existence of widespread, genetically uniform crops means they are also uniformly susceptible to the emergence of a new pest or disease, which can only be combated genetically by modifying the crop through the use of genes from

${ }^{183}$ See Reed Karaim, Variety, the Vanishing Crop, Wash. Post, Apr. 11, 1999, at B1; see generally Cary Fowler \& Pat Mooney, Shattering: Food, Politics and the Loss of Genetic DIVERSITY (1990).

${ }^{184}$ Approximately five million hectares of forest are lost each year in sub-Saharan Africa, principally to clearance for low-yield agriculture. See Paarlberg, supra note 57, at 33.

185 See Edith Brown Weiss, In Fairness to Future Generations 195, 221 (1989). 
the very landraces and wild varieties that are becoming increasingly less available. ${ }^{186}$ Loss of this diversity may decrease the options, particularly in developing states, of maintaining nutritional diets from wild and domesticated plants. ${ }^{187}$ This overall tendency is reinforced by strong international intellectual property protections for genetically modified products yet weak international law protections for biological diversity. ${ }^{188}$ While it is possible to store genetic material (germ plasm) in "gene banks," those gene banks are frozen in time, and are not readily accessible to traditional innovators (e.g., the farmer in Ethiopia) for experimentation.

For years, the global community has been concerned with the impact of biotechnology on biological diversity. The non-legally-binding action plan developed in 1992 at Rio-Agenda 21-contains a chapter dealing with environmentally sound management of biotechnology ${ }^{189}$ and the Convention on

${ }^{186}$ See Jane Rissler \& Margaret Mellon, Perils Amidst the Promise: Ecological Risks of Transgenic Crops in a Global Market 69-71 (1993); Jack Doyle, Altered Harvest: Agriculture, Genetics ANd the Fate of the World’s FoOd Supply (1985).

${ }^{187}$ See Ho, supra note 165, at 126-30.

${ }^{188}$ See Charles R. McManis, The Interface Between International Intellectual Property and Environmental Protection: Biodiversity and Biotechnology, 76 WASH. U.L.Q. 255, 269 (1998) ("[T]raditional agricultural innovation may be threatened, along with the very biodiversity that it has helped maintain, by a system of intellectual property protection that tends to reward the development of new and genetically improved, but highly uniform, and therefore potentially vulnerable, monocultures.").

${ }^{189}$ See Chapter 16 of Agenda 21: Program of Action for Sustainable Development, Rio de Janeiro, U.N. Doc. A/CONF.151/26 (3 vols. 1992). That chapter set forth the following goals: increasing the availability of food, feed and renewable raw materials; improving human health; enhancing protection of the environment; enhancing safety and developing international mechanisms for cooperation; and establishing enabling mechanisms for the development and the environmentally sound application of biotechnology. The Commission on Sustainable Development (CSD) designated UNIDO as the task manager for that chapter. For UNIDO's 1995 review of the progress in implementing the chapter, see UNIDO, Environmentally Sound Management of Biotechnology (1995). 
Biological Diversity focused on this issue as well. ${ }^{190}$ The most salient provisions of the Convention, however, simply call upon states "as far as possible and as appropriate" to pursue general measures concerning conservation of biological diversity. That general guidance is useful, but actual implementation is left to governments at the national level, where sufficient resources to do so may or may not exist. For developing states to avoid the long-term decline in biological diversity threatened by biotechnology, they will have to rely on assistance from various quarters, such as: programs operated by the Biodiversity Convention on Biological Diversity secretariat; sharing of information by, and transfers of technology and financial resources from, developed states; and initiatives in the nongovernmental sector (research institutes, environmental groups, and other private sector actors). Additional transnational structures that help foster and coordinate these disparate forms of assistance to the developing states, as well as promote assistance from other quarters (such as biotechnology companies) should be fully considered.

\section{The JURISGENERATIVE NATURE OF INTERNATIONAL LA W}

The global community would do well to consider whether the current transnational regulatory structure is adequate for addressing biotechnology concerns and, if not, how to improve it. The discussion in the prior section reveals diverse regimes containing disparate provisions for addressing the

Chapter 16 of Agenda 21 is on environmentally sound management of biotechnology, but other chapters are of relevance as well, such as Chapter 15 on the conservation of biological diversity and Chapters 23-32 on strengthening the role of major non-state actors.

190 See supra note 84. 
principal concerns about biotechnology in the transnational sphere. These provisions range from very general provisions in the Biodiversity Convention, to more specific provisions directed at particular conduct in the Biosafety Protocol, to provisions that seek to regulate the application of relevant intellectual property laws among states, to specific trade provisions plus process-oriented structures for dispute resolution at the WTO (linked to standard-setting entities such as the Codex Alimentarius). Global regulatory efforts have addressed some of the concerns about transnational biotechnology, but they by no means have resolved all these concerns, and it remains unclear whether they have resulted in a process for the sensible and timely resolution of emergent biotechnology concerns in the future.

Indeed, one might wonder whether existing law could possibly keep pace with the rapid changes in the field of biotechnology.

Yet there is another dimension of the transnational biotechnology regime that must be appreciated as well: the "jurisgenerative" nature of international law. ${ }^{191}$ International law in this area is not generated solely or even primarily through treaties; rather, it emerges from a more complex system of law creation, clarification, interpretation, and implementation that can be viewed as involving three fundamental processes. First, international law is clearly driven in many respects by the self-interest of

191 The term "jurisgenerative" - meaning a law-creating process - was coined by Robert Cover to describe a process in which interpretive communities create and give meaning to the law through their narratives and precepts. See Robert M. Cover, Foreward: Nomos and Narrative, 97 HARV. L. REV. 4, 40 (1983). Professor Harold Koh has applied the term to the process of transnational law. See Harold Hongju Koh, The 1998 Frankel Lecture: Bringing International Law Home, 35 Hous. L. REV. 623, 641 (1998); see also Harold Hongju Koh, Why Do Nations Obey International Law? 106 Yale L.J. 2599 (1997); Harold Hongju Koh, Transnational Legal Process, 75 NeB. L. ReV. 181 (1996). The following analysis has benefitted from Professor Koh's work on compliance in international law, in which he has identified categories of interaction, interpretation, and internalization similar to those used in this article. 
states. Second, international law develops through the social interaction of state and non-state actors.

Finally, international law is often defined, refined, and made effective upon being grounded in national law and society. The purpose of this section is to highlight the salient features of each of these lawcreating processes and to relate each to current efforts to regulate biotechnology. By doing so, it is hoped that the transnational biotechnology regime depicted in Part III will be seen in the context of an emergent, dynamic interaction among relevant regime actors, which in turn will point the direction for next steps by the global community, as outlined in Part V. ${ }^{192}$

\section{International Law as Driven by the Self-Interest of States}

International law is clearly driven in many respects by the self-interest of states: two states seeking peace will both find it in their interests to conclude and maintain a peace treaty viewed by both as legally binding. Yet our understanding of what it means for a state to act in its "self-interest" must be a robust one. States have multiple interests in multiple areas, as well as general interests in stability and efficiency in relations with other states, which can often be met by the creation of wide range of international rules and institutions that will be adhered to over the long-run, even if short-term gains

192 The broad categorizations set forth below cannot possibly capture the sophistication of the theories or theorists discussed. Indeed, while particular theorists might be placed within a broad category or school of thinking, upon close reading of their works there is considerable cross-over among categories. Further, in their works, different theorists focus on different aspects of transnational law-its sources, its structure, or its ability to compel compliance-making comparisons inexact. Nevertheless, the following broad groupings are helpful in understanding the contemporary structures effecting biotechnology in the global arena. 
could be achieved by deviation. Further, states are represented by persons, who by general nature would rather avoid breaking rules that would lead to condemnation by others. And states are not simply unitary actors, but actors whose decision-making is in many respects circumscribed by the interests of non-state actors. International lawyers and political scientists have posited various theories about how law is generated from the self-interest of states. This section will briefly discuss these theories, with particular attention to their relevance to transnational biotechnology.

As is well-known, in the post-World War II era, the whole concept of international law (at least in the United States) came under attack by Cold War realists, who viewed with great doubt, if not disdain, the idea that global rules could possibly "suppress the chaotic and dangerous aspirations of governments. ${ }^{\prime 193}$ For these realists, states inexorably seek to pursue maximization of their power, security and wealth vis-à-vis other states; they "abide" by international rules that advanced such interests and ignore those that did not unless faced with military or economic coercion by other, more powerful states. ${ }^{194}$ For hardened realists, viewing international law as a set of rules that dictate the behavior of states is both naive and dangerous utopianism. Such realism is a constant reminder of the limits of international law (as well as national law for that matter) in certain areas and the fact that a core feature of interstate behavior is the advancement by governments of what they perceive as their interests.

193 See George Kennan, American Diplomacy 1900-1950 at 95 (1984); see also Henry A. Kissinger, The Nature of Leadership, in AMERICAN FOREIGN POLICY 27-43 (1969).

194 "Neo-realists" follow this tradition, but focus less on the desire for power embedded in human nature, and more on systemic or structural causes of conflict and cooperation in international relations (e.g., scarcity of resources). See generally Kenneth N. WALtz, TheORY OF INTERNATIONAL POLITICS (1979). 
In the field of transnational biotechnology, realism helps explain on a general level why states declined to include in the Biodivesity Convention intrusive and costly obligations to conserve biological diversity, and why the United States has resisted both joining the Biodiversity Convention and the creation of a Biosafety Protocol. ${ }^{195}$ Other states, to a greater or lesser degree, have interests that are coincident with the United States on transnational biotechnology, but differ on some matters, such as the extent to which environmental concerns should ameliorate trade obligations. Those differences may turn on the other states' national interests in promoting greater protection for the environment or may turn on those states' assessment of their comparative advantage/disadvantage in the trade of genetically modified products. Many developing states view their national interests in biotechnology very differently from the United States and other developed nations, embracing treaty provisions that they believe will promote the transfer of financial resources, technology, and other assistance to their states. The

${ }^{195}$ As a bastion of free-market capitalism, the United States has long been a strong proponent of treaties that promote free trade so as to open foreign markets for U.S. goods and services; concomitantly, the United States has been wary of altering these treaties to address unproven risks to the environment, believing that to do so could lead to disguised restraints on trade. Similarly, as a bastion of innovative science and creative information, the United States has long been a proponent of strong global treaties for protecting intellectual property protection so as to reward U.S. innovation, most recently brought to fruition in the conclusion of the TRIPS Agreement; concomitantly, the United States has been wary of altering such treaties to account for the difficulties faced by developing nations in paying for emergent technologies. As the leading nation in development of biotechnology applications, the United States helped launch the negotiation of the Biodiversity Convention, welcoming provisions that would promote access to and preservation of genetic resources in states. Yet the United States thereafter sought to minimize, if not eliminate provisions, that would compel sharing of benefits from intellectual property derived from those resources or that would otherwise ameliorate intellectual property rights. Likewise, the United States resisted incorporation of provisions restricting international trade in genetically modified products, successfully pushing the matter into a subsequently-negotiated protocol, and then joining with like-minded states to narrowly tailor the provisions of that protocol. Instead, the United States repeatedly urged that trade matters be resolved within the context of the GATT. 
negotiations of the Convention on Biological Diversity and, more recently, of the Biosafety Protocol, demonstrated the complexity and diversity of these national interests. In the case of the Biosafety Protocol, various factions of states emerged in the negotiations: the European Union; the eastern and central European states; a "Like-Minded" group of developing states; a "Miami Group" of major agricultural exporters (Argentina, Australia, Canada, Chile, the United States, and Uruguay), and a “Compromise" group (Japan, Korea, Mexico, New Zealand, Norway, Singapore and Switzerland). The inability of these factions to broker an acceptable compromise led to a breakdown in negotiations in February 1999, and a one-year suspension before a protocol acceptable to all factions could emerge. ${ }^{196}$

Yet a hard-core realist paradigm that views norm-creation as driven wholly by immediate selfinterest goes too far; states do not and cannot seek on a day-to-day basis simply to maximize their short-term interests. States have long-term interests in the stability and efficiency of the system in which they operate, interests best served by establishing rules and institutions that promote predictability and reliability. Even prominent realists find it hard to deny that international law exists as a system of binding legal rules (in the sense that states habitually conform their behavior to the rules), even if in some areas and in some situations the rules are of doubtful efficacy. ${ }^{197}$ That binding system is a manifestation of the self-interest of states in developing efficient means for cooperation over the long-term, even if that

${ }^{196}$ See Gareth W. Schweizer, The Negotiation of the Cartagena Protocol on Biosafety, 6 ENv. Law . 577, 585-90 (2000); John Burgess, Trade Rules Set on Food Genetics, WASH. Post, Jan. 30, 2000, at A1; Andrew Pollack, 130 Nations Agree on Safety Rules for Biotech Food, N.Y. Times, Jan. 30, 2000, at 1.

197 See Hans J. Morgenthau, Politics Among Nations 265 (4th ed. 1967). 
means being held to rules that in the short-term do not serve their interests. The creation of the WTO and its system of binding dispute settlement is an example of such cooperation; states typically comply with WTO decisions that are adverse to their short-term interests (e.g., striking down a national program that subsidizes exports) so as to serve their long-term interests in being part of and benefitting from a global trading regime. Sometimes states fail to comply, but non-compliance results in the removal of some of the benefits of the trade regime in the form of WTO-blessed retaliation, as occurred in the Beef Hormones case. ${ }^{198}$ Because of economically-powerful constituencies, the WTO is a sophisticated regime with extensive treaties containing detailed rules and credible dispute resolution, whereas other regimes relating to intellectual property or environment are weaker. Nevertheless, all these regimes are essentially the means by which utility-maximizing states use legal norms (strong or weak) to coordinate behavior and facilitate optimal outcomes.

To overcome the shortcomings in the realists' utilitarian premise, contemporary international law and international relations theorists have sought a more complete explanation of international norm creation principally by observing and analyzing the manner in which states were increasingly engaging in cooperation through international organizations and other "regimes" over the course of the twentieth century. ${ }^{199}$ From an international lawyer's perspective, Louis Henkin acknowledged the utilitarian

${ }^{198}$ See supra notes $131-40$ and accompanying text.

${ }^{199}$ See Anne-Marie Slaughter et al., International Law and International Relations Theory: A New Generation of Interdisciplinary Scholarship, 92 Am. J. INT'L L. 367 (1998); Anne-Marie Slaughter Burley, International Law and International Relations Theory: A Dual Agenda, 87 Am. J. InT'L L. 205 (1993); Kenneth W. Abbott, Modern International Relations Theory: A Prospectus for International Lawyers, 14 YALE J. INT'L L. 335 (1989). International law theorists refer to "international law" while international relations theorists refer to "international regimes," but to a large extent the two disciplines have drawn similar conclusions using different methodologies. 
premise of the realists when he noted that "nations will observe international obligations unless violation promises an important balance of advantage over cost." ${ }^{200}$ Yet Henkin delved deeper into the nature of this cost and advantage analysis, finding of significance various external factors-such as the desire of a state for orderly international relations, to maintain a reputation of principled behavior, and to avoid adverse communal responses to its actions - as well as internal factors - such as a state's national law, history, tradition and values. ${ }^{201}$ International relations theorists preferred to speak in terms of "regimes," which they defined as "sets of implicit or explicit principles, norms, rules, and decision-making procedures around which actors' expectations converge in a given area of international relations."202 While states and their government leaders are important actors, regime theory envisions a broad spectrum of interests and preferences of non-state actors, such as international institutions, business groups, public interest groups, and individual citizens, that condition and influence state behavior. To the extent that policymakers seek effective and efficient transnational regimes so as to maximize the gains of all these actors, regime theory aspires to point the direction, by showing why cooperation fails in some instances and works in others. ${ }^{203}$

\footnotetext{
${ }^{200}$ Louis Henkin, How Nations Behave:Law and Foreign Policy 50 (2d ed. 1979).

${ }^{201}$ See id. at $49-68$.

202 See Stephen D. Krasner, Structural Causes and Regime Consequences: Regimes as
} Intervening Variables, in INTERNATIONAL REgIMES 1, 2 (Stephen D. Krasner ed., 1983); see generally Robert O. KeOHAne, After Hegemony:CoOperation And Discord in the World Political ECONOMy (1984); TheOries of InTERnAtional Regimes (Andreas Hasenclever et al. eds., Cambridge Studies in International Relations No., 55, 1997).

${ }^{203}$ Different schools and sub-schools of thought have emerged in this field. Some international relations theorists emphasize game theory, economics, industrial organization theory, and other disciplines as tools for identifying the conditions that prevent states from realizing potential gains from 
One strand of regime theory, for example, pursues models grounded in economic theory as a means of illuminating cooperation among states. Under this approach, international cooperation on issues such as arms control or environmental protection is essentially viewed as a public good, in that the states cooperating to achieve an objective (e.g., reduction in emission of greenhouse gases) incur all the costs in doing so, while the resultant benefit flows to all states, even those that do not cooperate. When faced with matters concerning the global welfare of states, a rational state would therefore chose not to cooperate (to "free ride"), thereby obtaining some benefits with no costs. Regime theorists look to various economic models to try to explain under what conditions states would seek to cooperate or seek to "defect" from cooperation, and what factors might be altered to induce cooperation. ${ }^{204}$ By

cooperation, and then study how institutions (or rules) can ameliorate those conditions. Other theorists are more broadly interested in the effects of formal cooperation on private, governmental, and supranational actors.

${ }^{204}$ See Bruce M. Russett \& John D. Sullivan, Collective Goods and International Organization, 25 INT'L ORG. 845 (1971). For instance, one might try to explain the likelihood of cooperation on issues of biotechnology among trade-oriented states and environmentally-sensitive states in game theory terms. In a simple $2 \times 2$ game, the explanation might argue that the conditions for a "Prisoner's Dilemma" game exist. See Robert CoOter \& Thomas Ulen, Law And Economics $34-$ 38 ( $3 \mathrm{~d}$ ed. 2000). While the two sets of states could achieve the most optimal outcome by cooperating so that scientifically-based, global, and enforceable regulations are placed on the biotechnology trade - presumably allowing most of its benefits while eliminating most of its perils - the dominant strategy of each set of states may be not to cooperate for fear that the other set would "defect," leading to a highly adverse outcome to the other set (thus, the biotechnology trade-oriented states would fear that cooperation in creation of a thorough and effective regime might actually lead down a slippery slope to complete bans, while the environmentally sensitive states would fear that doing so might lead to essentially unrestricted trade). Instead, the strategy of each set of states would be not to cooperate regardless of whether the other set decides to cooperate. If both follow their dominant strategy and fail to cooperate, a sub-optimal outcome (as compared to the situation where the two sets cooperate) is reached (e.g., largely unregulated bioprospecting and trade goes forward, but amidst an incoherent patchwork of unilateral bans or restrictions exist). Neither set is entirely happy (for the pro-trade states, there are limitations and uncertainty about trade; for the pro-environment states, there are still significant risks for human health and the environment), but neither has fallen into their worst case scenario. 
identifying those factors, such as reducing transaction costs and increasing information flows among states, these theorists seek to show how effective legal rules can be generated.

There are, however, considerable difficulties in using such models to describe accurately complex multilateral problems. As public choice theory has demonstrated, even rational actors often experience difficulty in cooperating, leading to sub-optimal outcomes that cannot be cured by greater information flow. Moreover, analytic devices such as game theoretic formulation or Edgeworth box diagrams $^{205}$ are far too abstract. On an issue such as transnational biotechnology, there are far too many participants in the negotiating process, whose identities may or may not be known at the outset, and whose positions and preferences on issues and sub-issues are determined and redetermined only over long periods of time and in response to changing events. ${ }^{206}$ As Oran R. Young notes, "mapping

Observing all this, the international relations theorist might posit that by promoting a greater flow of information between the two sets of states, they would be motivated - as rational utility maximizers - to cooperate and thereby realize feasible joint gains. The theorist would then look for ways to promote such information flow. In the transactions costs context, the theorist might posit that the costs to tradeoriented states to combat trade bans unilaterally and the costs to environmentally-sensitive states in trying unilaterally to prevent identified risks from biotechnology applications are such that both would prefer the relatively lower costs of bargaining within a shared regime. See RoBERT O. KeOHANE, InTERnATIONAL Institutions AND State Power 167 (1989) ("whenever the costs of communication, monitoring, and enforcement are relatively low compared to the benefits to be derived from political exchange," international institutions appear). On the application of game theory generally to international relations, see Andrew Kydd \& Duncan Snidal, Progress in Game-Theoretical Analysis of International Regimes, in REGIME THEORY AND InTERnATIONAL RELATIONS 112 (Volker Rittberger \& Peter Mayer eds., 1993).

${ }^{205}$ An Edgeworth box diagram depicts a well-defined contract curve, typically between two parties and on two issues. By charting the indifference curves of the two parties in "issue space," the diagram seeks to show where combinations of the two issues are of equal utility to the two parties, and define where no agreement is possible and where there is a "bargaining set."

206 Theorists following such utilitarian models might see different outcomes or "payoffs" in the field of transnational biotechnology, leading them to describe the "game" as something other than a 
the contours of real-world collective-action problems in terms of such analytic models is seldom a feasible proposition, and our ability to foresee the consequences, unfolding over time, which result from the choice of specific options is particularly limited in connection with ongoing arrangements such as international regimes."207

Nevertheless, these models have reinforced a further critical element in understanding the selfinterest of states, which is that it is a mistake to view states as operating within just a "single-level game." Although both traditional international law and international relations theorists have focused on the role of governments in resolution of international problems or issues, game theoreticians have demonstrated through their models why governments should not be viewed as unitary, rational actors but, rather, as actors whose decision-making is severely circumscribed by internal bargaining at the national level. "Two-level game theory" postulates that an effective means of ensuring that a viable range of outcomes acceptable to relevant actors (a "win-set") exists is to pay attention to the value of side-payments to reduce opposition to a particular outcome by a recalcitrant actor within the national

Prisoner's Dilemma game (such as a "Stag Hunt" game, "Chicken" game, "Tender Trap" game, "Hawk-Dove" game, and "Battle of the Sexes" game). On the variety of possible "games," see Jack Hirshleifer, Evolutionary Models in Economics and Law: Cooperation Versus Conflict Strategies, in ECONOMIC BEHAVIOR In AdVERSITy 223 (1987). Thus, even the simplistic parties and issues posited supra, note 204, may better apply to some other type of "game," given uncertainties about the likely payoffs for cooperation or defection.

${ }^{207}$ See Oran R. Young, The Politics of International Regime Formation: Managing Natural Resources and the Environment, 43 INT'L ORG. 349, 359 (1989); see also Duncan Snidal, Coordination Versus Prisoners' Dilemma: Implications for International Cooperation and Regimes, 79 Am. Pol. Scr. Rev. 923 (1985); R. Harrison Wagner, The Theory of Games and the Problem of International Cooperation, 77 Am. PoL. SCI. REV. 330, 331 (1983). 
coalition. ${ }^{208}$ Such side-payments need not be monetary; they can occur through linkages to other issues, such that the recalcitrant actor receives a benefit that might not otherwise have arisen in the course of the negotiations of the issue at hand..$^{209}$

This more robust perception of the "self-interest of states" captures key aspects of the field of transnational biotechnology. In advancing their long-term interests, states have come together to create fairly complex regimes to regulate particular sectors of relevant behavior: trade, environment, intellectual property, distribution of resources, and so on. Each of these regimes is a system of norms which translates a long-term interest in promotion of trade, protection of intellectual property, protection of the

${ }^{208}$ In particular, Robert Putnam has pursued the concept of "two-level" games so as to provide a model for understanding the implications of national politics for international negotiations. See Robert D. Putnam, Diplomacy and Domestic Politics: The Logic of Two Level Games, 42 InT'L ORG. 427 (1988). For Putnam's models, the range of possible agreements among the relevant governments at the international level as mapped onto the range of agreements acceptable to a majority of relevant actors at the national level of a state constitutes the "win-set" for that state. Putnam then formulates certain hypotheses from this approach, such as that states with small "win-sets" have a bargaining advantage over states with larger "win-sets," because the former can demonstrate that they have little negotiating flexibility. Others have refined these hypotheses, such as by noting the relevance of complete information among relevant actors, see Keisuke Iida, When and How Do Domestic Constraints Matter? 37 J. Conflict Resol. 403 (1993), and the effect of a veto by one actor on the formation of majority national coalitions. See Jongryn Mo, The Logic of Two-Level Games with Endogenous Domestic Coalitions, 38 J. Conflict Resol. 402 (1994).

Of course, two-level game theory also has limits when being applied to complex transnational problems. See, e.g., Robert J. Schmidt, Jr., International Negotiations Paralyzed by Domestic Politics: Two-Level Game Theory and the Problem of the Pacific Salmon Commission, 26 ENVTL. L. 95 (1996) (engaging in an extensive discussion of the models, but essentially concluding that the solution to resolving the salmon depletion in the north Pacific lay in paying Alaskans to harvest less). Yet it focuses attention on the fact that, in promoting the development of a sensible and effective regime for transnational biotechnology, one must pay attention to the building of national coalitions and, this article suggests, transnational coalitions.

${ }^{209}$ See Frederick W. Mayer, Managing Domestic Differences in International Negotiations: The Strategic Use of Internal Side-Payments, 46 INT’L ORG. 793 (1992). 
environment, and the equitable advancement of states into a code of conduct by which states can assess each other's behavior and fidelity to the system in the short-term. Yet, while these regimes were established by states, they are of great interest to non-state actors-including non-governmental organizations, multinational organizations, indigenous groups, and others - and in many respects these regimes are directed at the behavior of private actors. ${ }^{210}$ Those actors play a key role in conditioning the attitudes of governments, by informing governments officials about the nature of a particular problem and about the private interests that might be affected in resolving the problem, and by persuading government officials to adopt a particular position. Paying attention to the interests of these non-state actors across a range of issues is important in understanding how international cooperation has developed in the field of transnational biotechnology. Thus, in pursuing international negotiation of these regimes, the U.S. Executive Branch has held hearings and maintained advisory committees to obtain

${ }^{210}$ See Peter J. Spiro, New Global Communities: Nongovernmental Organizations in International Decision-Making Institutions, WASH. Q., Winter 1995, at 45, 47 ("This explosion in nongovernmental activity reflects the dramatically heightened permeability of national borders and improvements in communications that have allowed territorially dispersed individuals to develop common agendas and objectives at the international level."). Kenneth Abbott notes that the revolutionary development of having non-state actors participate in international politics and the development of international law is appealing for various reasons: promotion of democracy generally; inclusion of the most affected groups in decision-making; exchange of information; ability of non-state actors to monitor state compliance; and development of public support for international agreements. See Kenneth W. Abbott, "Economic” Issues and Political Participation: The Evolving Boundaries of International Federalism, 18 CARDOZO L. REV. 971, 1007-09 (1996); see also Julie Mertus, Considering Nonstate Actors in the New Millennium: Toward Expanded Participation in Norm Generation and Norm Application, 32 N.Y.U. J. INT'L L. \& POL. 537 (2000); Kal Raustiala, States, NGOs and International Environmental Institutions, 41 InT'L STUD. Q. 719 (1997); Paul Wapner, Politics Beyond the State: Environmental Activism and World Civil Politics, in GrEEN Planet Blues:Environmental Politics from Stockholm to K yoto 118, 130 (Ken Conca \& Geoffrey D. Dabelko eds., 2d ed. 1998). 
information and advice from private entities, has been pressured to respond to private sector needs through the filter of Congress, and has allowed private sector representatives to participate as delegates on U.S. Government negotiating teams. ${ }^{211}$ U.S. non-governmental organizations in this area range from industry organizations, such as the Biotechnology Industry Organization (BIO) $)^{212}$ and the American Biological Safety Association (ABSA) $)^{213}$ to environmental organizations, such as the World Wildlife Foundation, to consumer groups, such as the Consumer's Choice Council, ${ }^{214}$ and so on. In addition to lobbying activities, $\mathrm{BIO}$ has produced its own self-regulation in the form of guidelines on the protection of health, safety, and the environment in the use of biotechnology products. ${ }^{215}$

Finally, non-governmental organizations are often themselves transnational in nature. They form transnational networks of experts and activists in a variety of key states all organized to push for the objectives of the organization, and thus arguably transform the "two-level" game into a "multi-level game". These "transnational norm entrepreneurs" are readily apparent in the field of transnational

${ }^{211}$ The Seattle trade summit failure prompted the U.S. government to pursue even further procedures for advice from non-governmental organizations on trade issues. See USTR Press Release on USTR Charlene Barshefsky and Secretary of Commerce William M. Daley to Establish New Procedures for Advice from Non-Governmental Organizations (Jan. 11, 2000), $<$ http://www.ustr.gov>.

${ }^{212}$ For information, see $<$ http://www.bio.org $>$.

${ }^{213}$ For information, see <http://www.absa.org $>$.

${ }^{214}$ For information, see $<$ http://www.consumerscouncil.org $>$.

${ }^{215}$ See BIO, Statement of Principles, <http://www.bio.org/laws/principles.html> (visited July 20, 2000). 
biotechnology. Environmental groups such as the Netherlands-based Greenpeace International ${ }^{216}$ and U.K.-based Friends of the Earth ${ }^{217}$ have been highly active in lobbying states on global rules for restricting or banning genetically modified products. Conversely, European biotechnology companies have banded together to form EuropaBio ${ }^{218}$ to prevent such restrictions, which in turn has joined with Canadian, Japanese, and U.S. biotechnology trade associations and companies to form the International Bioindustry Forum (IBF).

Fully addressing the "two-level" or "multi-level" game would take account of possibilities for including in the development of treaty regimes greater involvement of private actors from different areas of interest or expertise. Greater participation of non-state actors in the negotiating process through consultation and status as observers or even delegation members is one approach. Another would be to focus on the development of fora for non-state actors to present and negotiate their positions separate from the formal treaty-making process. Non-state actors have held major conferences of their own, but to date the vast majority of organizations taking part in these conferences are all of the same general type, resulting in positions unacceptable to other non-governmental organizations and ultimately to states. ${ }^{219}$ Consequently, as discussed in Part V, other approaches should be considered.

${ }^{216}$ For information, see $<$ http://www.greenpeace.org/ qgeneng $>$.

${ }^{217}$ For information, see $<$ http://www.foe.co.uk $>$.

${ }^{218}$ For information, see <http://www .europa-bio.be>.

${ }^{219}$ See Abbott, supra note 210, at 1009. 
International Law as Driven by Social Interaction Among Transnational Actors

Focusing exclusively on the self-interest of states and non-state actors, however, misses part of the dynamism of international law. States and other transnational actors do not operate in a vacuum; they operate as part of a transnational social structure, meaning that they are constantly interacting in ways that shape those interests, thereby altering the creation, interpretation, and implementation of international law. International lawyers and political scientists have posited various theories about how law is generated from the interactions of states and transnational actors. This section will briefly discuss these theories, with particular attention to their relevance to transnational biotechnology.

Some international law theorists have developed this notion by exploring the internal nature of law, principally as a means of explaining why the law "binds" or at least influences state behavior. Thomas Franck argues that effective international law is grounded in notions of "fairness;" fairness both in the process by which the law is created ${ }^{220}$ and fairness in the substantive law itself. ${ }^{221}$ Though Franck does not put it in quite these terms, the way in which international law becomes effective turns on the

${ }^{220}$ Franck's touchstone for procedural fairness is the concept of the "legitimacy" of rules. Legitimacy arises when a rule exhibits certain features: clarity; validation by the global community; conceptual coherence; and conformity with the normative hierarchy of the international rule system. Where a rule is "legitimate," it exerts a "compliance pull" on those addressed. See generally THOMAS M. Franck, The Power of Legitimacy Among Nations (1990).

${ }^{221}$ Franck's touchstone for substantive fairness is the concept of the "justice" of rules. Justice requires the balancing of different variables, including traditional notions of equity in international law. Where a rule is "just," it, too, exerts a "compliance pull" on those addressed. See generally THOmAS M. Franck, FAIRNESS In INTERNATIONAL LAW AND InSTITUTIONS (1995). 
states and non-state actors interact with one another so as to create the law and take account of the views of one another in setting the law's content. On a different track, adherents to the McDougal/Lasswell “policy-oriented” jurisprudence ${ }^{222}$ view international law as a discrete part of the social process at large, a part that involves an ongoing process of authoritative and controlling decision. The decision process involves ascertaining the policy goals of the community, goals that should be guided by a set of scientifically-derived, globally-applicable normative values surrounding the notion of human dignity. In assessing the effects of social interaction on international law, other international law scholars have focused on the political nature of states themselves ${ }^{223}$ or the nature of treaty regimes. ${ }^{224}$

${ }^{222}$ This jurisprudence (also known as the "New Haven School") derives from the writings of Professors Myres McDougal and Harold Lasswell. See generally Harold D. LASswell \& MYres S. McDougal, Jurisprudence for a Free Society: Studies in La w , Science AND PoliCy (1992). For them, law is essentially "decisions that are made by the persons who are expected to make them, in accordance with criteria expected by community members, in established structures of authority, with sufficient bases in effective power to secure consequential control, and by authorized procedures." Siegfried Wiessner \& Andrew R. Willard, Policy-Oriented Jurisprudence and Human Rights Abuses in Internal Conflict: Toward a World Public Order of Human Dignity, 93 AM . J. INT'L L. 316, 319 (1999).

${ }^{223}$ See Anne-Marie Slaughter, International Law in a World of Liberal States, 6 EuR. J. INT'L L. 503 (1995); Anne-Marie Burley, Law Among Liberal States: Liberal Internationalism and the Act of State Doctrine, 92 CoLum. L. REV. 1907 (1992) (arguing that transnational legal norms tend to develop among liberal democratic states).

${ }^{224}$ For instance, Chayes and Chayes depict international law as principally a series of complex, treaty-based regulatory regimes that do not rely on sanctions for enforcement, since sanctions are costly, erratically imposed, and therefore deficient in legitimacy. Instead, states create and comply with the rule system of a treaty-based regulatory regime because it is efficient to do so and because it promotes the long-term interests of the states (at least if it is well-negotiated), but also because representatives of states instinctively are drawn to compliance with rules. To the extent that states do not comply, the reasons lie less in a pathological promotion of short-term self-interest and more in ambiguities present in the rules, the limitations on the capacity of states to comply with the rules, and the difficulties in adapting the rules to changing conditions. See ABram CHAYES \& ANTONIA HANDLER Chayes, The New Sovereignty: Compliance with International Regulatory Agreements 
While these legal theories differ in many ways, they are all oriented toward explicating the social relationships of states as a key element in transnational norm generation. Non-state actors play an important role in this social interaction; direct political involvement of non-governmental organizations enhances the interaction of governments so as to promote what some would call a "global civil society."225

Similar reasoning exists in the works of some international relations theorists, particularly those regarded as "constructivists." For them, regime theory is useful not just in assessing the power and interests of states, but also the way in which they conceive themselves as interacting with other states. In particular, constructivists have noted that states define their interests "in the context of internationally held norms and understandings about what is good and appropriate. ${ }^{226}$ Thus, the norm-generating behavior of states, and other transnational actors, is not driven just by national interests; it is also driven by how states identify themselves, by deeply embedded values they possess, and by beliefs that they

1-28 (1995). Adherents to the "international legal process" school focus on how and why decisionmaking competence is allocated in given area of international affairs, the ways in which particular institutions in that area (and the system as a whole) restrain and organize national and individual behavior, and the conditions under which those institutions emerge. This school of scholarship has its origins in Abram Chayes et AL., InTERnational Legal Process: MATERIALs FOR AN INTRODUCTORY COURSE (1968).

225 This notion of a global civil society is sometimes referred to as Grotian liberalism. See Gerry J. Simpson, Imagined Consent: Democratic Liberalism in International Legal Theory, 1994 Austl. Y.B. InT'L L. 103, 107-08; Dianne Otto, Nongovernmental Organizations in the United Nations System: The Emerging Role of International Civil Society, 18 Hum. RTs. Q. 107, 132-33 (1996); see also Richard Price, Reversing the Gun Sights: Transnational Civil Society Targets Land Mines, 52 InT'L ORG. 613 (1998).

${ }^{226}$ See Martha Finnemore, National Interests in International Society 2 (Cornell Studies in Political Economy, 1996). 
share or do not share with other states. Depending on their nature, some states may follow Hobbes and view each other as enemies, but others will follow Locke and view each other as friendly competitors or follow Kant and view each other as friends, leading to the development among them of transnational legal rules and the pacific settlement of disputes. ${ }^{227}$ Transnational norms, then, are part of the basic cognitive structure of the international system which defines the identities of the relevant actors.

The importance of this social interaction may be reinforced by reference to game theoretic formulations, which note that an indeterminate series of interactions among the relevant actors of the regime can lead to the evolution of cooperative strategies, since cooperatively inclined actors have a relative advantage over less cooperative actors. ${ }^{228}$ Direct application of such analysis to real-world multilateral cooperation on complex issues is problematic and even regime theorists concede that infinite iterations of such a game do not guarantee that cooperation will evolve. The lesson, however, is that an indeterminate series of interactions by the relevant actors in the regime can help overcome obstacles that might otherwise exist in achieving cooperation. As such, regime theorists look for methods of

\section{See generally AleXander Wendt, Social THeORy of InTERnAtional Politics (1999); John Gerard Ruggie, Constructing the World Polity:Essays on International INSTITUTIONALIZATION (1998).}

${ }^{228}$ In the Prisoner's Dilemma game, the players involved in a single game readily defect from cooperation, but players involved in the repeated game tend to alter their strategy, first selecting cooperation and thereafter deciding whether to continue cooperating based on the strategy selected by the other actor. See generally Robert Axelrod, The Evolution of CoOPERATION (1984); Elliott Sober, Stable Cooperation in Iterated Prisoners' Delimmas, 8 Econ. \& PHIL. 127 (1992). In essence, the players value the prospect of future cooperation (future "payoffs"), and are willing to risk short-term loss from the other player's defection in the hope of obtaining long-term gains. Reverting to the $2 \times 2$ game discussed supra note 204, the preferable outcome for both sets of actors - one that allows optimal uses of biotechnology to continue, while placing global (or perhaps a series of regional) restraints on those uses deemed of highest risk - might best be achieved if the two sets of actors are not engaged in a one-time negotiation but, rather, involved in recurring iterations of negotiations 
lengthening the "shadow of the future" (i.e., increasing the likelihood of future payoffs) so as to increase the prospects for cooperation. ${ }^{229}$

This social interaction of states in the field of transnational biotechnology is readily apparent.

Within each of the regulatory treaty regimes previously discussed, such as the WTO, WIPO, or the

${ }^{229}$ See, e.g., Robert Axelrod \& Robert O. Keohane, Achieving Cooperation Under Anarchy: Strategies and Institutions, 38 WorLd PoL. 226, 232-34 (1985). For interesting applications of iterative theory to international law, see John K. Setear, Ozone, Iteration, and International Law, 40 VA. J. InT'L L. 193 (1999); John K. Setear, An Iterative Perspective on Treaties: A Synthesis of International Relations Theory and International Law, 37 HARV. INT'L L.J. 139 (1996).

The presence of "iterated games," at least to a certain extent, may be discerned in various existing international environmental regimes. While international environmental regimes developed in the 1960's and 1970's tended to aim for static, one-time solutions to an existing transnational problem, more recent regimes have pursued the "framework-protocol" approach, whereby a regime is established that envisages repeated negotiations among states to resolve a given problem-area over time. The U.N. Framework Convention on Climate Change, opened for signature June 4, 1992, S. Treaty Doc. No. 102-38 (1992), 31 I.L.M. 849 (1992), the Montreal Protocol on Substances That Deplete the Ozone Layer, Sept. 16, 1987, S. Treaty Doc. No. 100-10 (1987), 26 I.L.M. 1541 (1987), and Long-Range Transboundary Air Pollution Agreement (LRTAP), Nov. 13, 1979, TIAS No. 10541, 1302 U.N.T.S. 217, are all examples of such an approach. Although states are incapable of reaching a cooperative solution as part of a single negotiation, over time they can be induced to cooperate (by amending or revising prior agreements) as they perceive pay-offs from the continued and increasing cooperation of other states. (Other factors are also in play, such as improved understandings over time of the underlying science concerning the problem.) Even within existing regimes that do not follow the framework-protocol approach. regimes can be seen to evolve and increase in strength due to repeated interactions of the state parties. Typically this occurs as part of the periodic meetings of the state parties at which decision on strengthening the implementation of the regime may be taken.

However, some scholars question whether the treaty-protocol approach is preferred, noting that there may be greater value in concluding a fully developed regime at the start among those states that are prepared to undertake serious obligations, allowing others to follow later when they are prepared to accept the regime. See George W. Downs et al., The Transformational Model of International Regime Design: Triumph of Hope or Experience?, 38 Colum . J. TRANSNAT'L L. 465 (2000). 
Biodiversity Convention - and other organizations as well ${ }^{230}$ - there is constant interaction among diplomatic representatives and (perhaps more importantly) experts of states on issues concerning biotechnology that condition state attitudes. Although formally meant to serve as the instrument of states, the secretariats of these organizations are also extremely important in synthesizing the attitudes and expectations of states, and using that information to set the agenda for future work of the institution. Certain secretariats, such as that of the Convention on Biological Diversity, have it as part of their mission to engage in training and education programs, principally for developing states. States, of course, continue to interact bilaterally with one another, often through cooperative activities of nondiplomatic regulatory officials. ${ }^{231}$

Such social interaction may ultimately affect U.S. Government resistance to joining the Convention on Biological Diversity and the Biosafety Protocol. That resistance may weaken due to a combination of U.S. self-interest and the perception that the rules set forth in those treaties are fair. Self-interest may arise from the fact that even if the United States does not join these treaties, the United States will need to abide by their rules when trading genetically modified products, since the

${ }^{230}$ For instance, the FAO has established a Commission on Genetic Resources for Food and Agriculture (CGRFA), which serves as a permanent forum where governments discuss and negotiate matters relevant to genetic resources for food and agriculture. The main objectives of the CGRFA are to ensure the conservation and sustainable utilization of genetic resources for food and agriculture, as well the fair and equitable sharing of benefits derived from their use. The Commission aims to reach international consensus through negotiations on areas of global interest. Information is available at $<$ http://www.fao.org/ag/cgrfa>.

${ }^{231}$ For instance, regulatory officials of the USDA Animal and Plant Health Inspection Service (APHIS) and the Canadian Food Inspection Agency meet regularly to compare and harmonize the molecular genetic characterization components of their regulatory review processes for genetically modified plants. See Canada and United States Bilateral on Agricultural Biotechnology (July 15-16, 1998), <http://www.cfia-acia.agr.ca/english/plaveg/pbo/usda01_e.shtml>. 
Protocol's rules will be applied by state parties to which the U.S. exports or from which it imports such organisms. Hence, the United States will either face a shrinking pool of trading partners or will need to abide by the Protocol's rules, in which case it may be motivated to join the Convention and its Protocol so as to influence future developments (such as the development of liability rules). The perception of fairness may arise from the fact that the rules of these conventions were negotiated and adopted by a large number of states based on compromises among a wide variety of viewpoints. Yet even if the United States does not join the Biodiversity Convention, the social interaction of states within that regime, and other regimes relevant to transnational biotechnology, are inescapably affecting the attitudes of the global civil society on how best to regulate transnational biotechnology.

The social interaction of non-state actors concerned with biotechnology issues may be less apparent, but such interaction does occur since non-state actors are involved in negotiations of new treaties, in conferences of the states parties to existing treaties, and as parts of associated working groups, typically as observers. Further, the Biological Diversity Convention and the Biosafety Protocol seek to harness the power of the Internet as a means for helping states and non-state actors exchange scientific, technical, environmental, and legal information about genetically modified products in a manner calculated to be neutral, accessible, cost-effective, and transparent.

Social interactions of actors trans-regime occurs but remains problematic. As discussed above, WTO agreements make use of international standards from organizations such as Codex Alimentarius, and the Biosafety Protocol made somewhat tortured efforts to explain its connection to the WTO. Further, various relevant international organizations have sought to create cooperative structures among them, such as the informal working group on biosafety formed by UNIDO, UNEP, 
WHO, and FAO. ${ }^{232}$ In November 1999, the WTO and UNEP concluded a cooperative arrangement which may be a harbinger of others to come. ${ }^{233}$ However, these cooperative arrangements are uneven and, in any event, do little to promote social interaction of private actors across regimes. In the absence of clear direction from existing international regimes, private actors have begun hesitantly engaging in associations and bargaining across borders in efforts to advance their interests. Several examples exist in the field of transnational biotechnology.

For instance, while much blood was spilt in inter-state negotiations over treaty language on whether there should be a transfer of biotechnology from the developed world to the developing world, in fact several U.S. and U.K. companies (including Novartis, AgrEvo, Monsanto, Zeneca, and Pioneer Hi-Bred) are transferring without charge their biotechnology for some projects in some developing states, often with the assistance of governmental or non-governmental associations. In some situations, the relevant company may have reached a conclusion that deployment of the biotechnology application in the developing state is not commercially feasible and therefore donates it. Thus, an nongovernmental, non-profit organization called the International Service for the Acquisition of Agribiotech Applications (ISAAA) — based in the United States but with offices in Kenya, the Philippines, and the United Kingdom - has brokered the transfer of such technology from U.S. companies mainly to

${ }^{232}$ See UNEP, Background on Biosafety (visited July 2, 2000), $<$ http://irptc.unep.ch/biodiv/bakgd01.html>.

${ }^{233}$ See WTO Press Release on Elements of Cooperation Between the WTO and UNEP, WTO Doc. Press/154 (Nov. 29, 1999) <http://www.wto.org/ddf/ep/D5/D5142e.doc>. Under the arrangement, the two organizations pledged to foster cooperation through sharing of information, participation in each other's meetings, and working together on capacity building for developing states and states in transition, so as to build awareness of linkages between trade, environment, and sustainable development 
address the needs of small scale and resource poor farmers, such as virus-resistant melons to a Costa Rican research center. Similarly, the Rockefeller Foundation sponsors a Rice Biotechnology Network, that has been instrumental in assisting states such as the Philippines in receiving cost-free genetically engineered rice germ plasm for development. Monsanto has collaborated with the U.S. Agency for International Development (AID) to provide a virus-resistant sweet potato to the Kenya Agricultural Research Institute, while at the same time offering royalty-free licenses for all of its technologies that can help further development of "golden rice" and other pro-vitamin A-enhanced rice varieties. ${ }^{234}$ In some situations, the motivation of the biotechnology company is more complex. According to the Executive Director of the ISAAA, the rationale "is that appropriate regulations, seed distribution systems, and trust and confidence have to be built both for humanitarian reasons and as a pre-cursor for licensing arrangements and the building of various forms of alliances and joint ventures . . ."235

Conversely, while much attention was paid by developed states to the need for access to genetic resources in developing states, quasi-private structures are at the forefront of controlling such access. For instance, in 1971 the Consultative Group on International Agricultural Research (CGIAR) was established as an informal association of fifty-eight public and private sector donors of developed

${ }^{234}$ See Joel I. Cohen \& John Komen, Research Collaboration, Management and Technology Transfer; Meeting the Needs of Developing Countries, in Plant Biotechnology Transfer to DeVEloping Countries, supra note 30, at 253, 263, tbl. 19.3; Monsanto Press Release on Monsanto Adds Support For "Golden Rice"; Opens Its Genome Sequence Data To Worldwide Research Community (Aug. 4, 2000), <http://www.monsanto.com/monsanto/mediacenter/2000/00aug4_goldenrice.html>.

${ }^{235}$ Anatole Krattiger, The Importance of Ag-Biotech to Global Prosperity at 6 (ISAAA Briefs No. 6, 1998) <http://www.isaaa.org/brief6.htm>; see also ANATOLE F. KRATTIGER, Insect Resistance in Crops: A Case Study of BaCILlus thuringiensis (BT) AND ITs Transfer to DeVeloping Countries 24 (ISAAA Briefs No. 2, 1997) <http://www.isaaa.org/brief2.htm>. 
states, supporting sixteen international research centers, located mostly in developing states, some of which have sixteen ex situ collections of plant genetic resources for food and agriculture held in trust for the international community and available in accordance with CGIAR policy. ${ }^{236}$ Distribution of the genetic resources to private parties, including universities and research centers, typically take the form of "material transfer agreements." 237 However, because of the strong movement toward reducing genetic resources to intellectual property rights, some centers and other entities controlling access to genetic resources have reacted by patenting newly developed varieties and conditioning access to the genetic material on agreements for the sharing of benefits. For example, the International Maize and Wheat Center, a nonprofit agency located in Texcoco, Mexico, is shifting from allowing free access to its vast genetic material to instead patenting the new varieties it develops and otherwise conditioning access. ${ }^{238}$ Such restrictions, in turn, have prompted biotechnology companies to pursue cooperative arrangements for uncovering useful genetic material. Thus, Merck \& Co. has undertaken a cooperative

236 The World Bank, the U.N. Food and Agricultural Organization (FAO), the U.N. Development Programme (UNDP), and the U.N. Environment Programme (UNEP) are cosponsors of the CGIAR. Information on CGIAR may be found on the Internet at <http://www.cgiar.org $>$. In 1974, CGIAR established the International Board for Plant Genetic Resources (IBPGR) to coordinate this network of seed banks. The seed banks concentrate on conserving plants for agricultural use. See N.C. Brady, Modern Biotechnology at International Agricultural Research Centers, in PLANT Biotechnology Transfer to Developing Countries, supra note 30, at 245. The FAO and CGIAR concluded an agreement on Oct. 26, 1994, making clear that the plant genetic resources in CGIAR gene banks are held in trust for the international community.

${ }^{237}$ See OECD REPORT, supra note 36, at 8-9, 24-25, annex IV; see generally W. LESSER, Sustainable Use of Genetic Resources Under the Convention on Biological Diversity (1998).

${ }^{238}$ See Anthony DePalma, The "Slippery Slope” of Patenting Farmers' Crops, N.Y. Times, May 24, 2000, at A4. 
research program in Costa Rica, promising to share profits should it uncover an economically viable drug. ${ }^{239}$ The ISAAA is pursuing possibilities for joint ventures between selected Asian states and U.S. companies for the Asian supply of rice germ plasm in exchange for U.S. companies supplying rice genetically modified to resist disease. ${ }^{240}$ The U.S. National Cancer Institute has undertaken contractual agreements, called a Letter of Collection Agreement, with numerous developing states, whereby the NCI screens extracts of plants from, and shares its findings with, the source state. If a commercial product results, the NCI obtains a patent, and a licensee is sought who would enter into an agreement with the source state concerning royalties and purchase of the source material. ${ }^{241}$ When agreements are concluded between a party possessing genetic resources and a party seeking to conduct research and development of the resource for commercial use, they are referred to as "bioprospecting" or "material

${ }^{239}$ See Michael D. Coughlin, Jr., Recent Development, Using the Merck-INBio Agreement to Clarify the Convention on Biological Diversity, 31 Colum. J. Transnat'L L. 337 (1993). But see Joan Martinez-Alier, The Merchandising of Biodiversity, in JusTICE, PROPERTY AND THE Environment: Social And Legal Perspectives 194, 201-03 (Tim Hayward \& John O’Neill, eds., 1997) (criticizing agreements such as exist between Merck and Costa Rica). See generally WALTER V. Reid et Al., World Resources Institute, Biodiversity Prospecting: Using Genetic Resources for Sustainable Development (1993); Darrell A. Posey \& Graham Dutfield, Beyond Intellectual Property:Tow ard Traditional Resource Rights For Indigenous PeOples AND Local Communities (1996).

240 See Krattiger, The Importance of Ag-Biotech to Global Prosperity, supra note 235, at 18-19. Rice is arguably the world's most important food, upon which almost two billion people rely for nourishment, and yet is susceptible to numerous destructive diseases, insects, fungi, and bacteria. See Pamela C. Ronald, Making Rice Disease-Resistant, ScI. Am., Nov. 1997, at 100. For a general discussion of the work of ISAAA as of mid-1994, see K.V. Raman, Facilitating Plant Biotechnology Transfer to Developing Countries, in Plant Biotechnology Transfer to DeVEloping Countries, supra note 30, at 267.

${ }^{241}$ For an sample of the NCI Letter of Collection, see OECDREPORT, supra note 36, at annex $\mathrm{V}$. 
transfer" agreements, which typically provide for payment for the genetic samples as well as royalty payments if a successful commercial exploitation is achieved. ${ }^{242}$ Unfortunately, as a general matter there is inadequate dialogue among the relevant actors regarding access to genetic resources, attributable in part to the limited opportunity for interaction. ${ }^{243}$

Finally, while much attention has been paid in international negotiations to the conditions under which intellectual property must be protected, even in the absence of such protections (making private licensing arrangements unlikely), there are options for transferring biotechnology applications. If nonstate actors can identify particular biotechnology applications that are of interest to an importing state (e.g., fruits engineered as edible vaccines), they may be able to work with the public institutions of the exporting and importing states to conclude contractual agreements regarding transfer of particular biotechnology applications where the rights of the producer are protected. A key problem, however, is that certain non-state actors typically do not have their interests adequately represented in relevant fora so as to promote such transfers. For instance, in the debate over export bans on genetically modified

${ }^{242}$ See Daniel M. Putterman, Model Material Transfer Agreements for Equitable Biodiversity Prospecting, in ACCess to Genetic Resources:StrategIEs fOR Sharing Benefits 299 (John Mugabe et al. eds., Afr. Ctr. for Tech Studies Envtl. Pol'y Ser. No. 8, 1997); Daniel M. Putterman, Model Material Transfer Agreements for Equitable Biodiversity Prospecting, 7 Colo. J. INT'L ENVTL. L. \& POL'Y 149 (1995). An analogue to this solely within the United States is the bioprospecting agreement concluded by Yellowstone National Park with a San Diego corporation, whereby the latter will pay a lump sum payment to the National Park Service, as well as a percentage of any royalties from commercially viable, genetically modified products derived from microbes found in Yellowstone's geysers and hot springs. See Andrew Pollack, Yellowstone-Biotechnology Deal Is Suspended by a Federal Judge, N.Y. Times, Mar. 26, 1999, at A17; see also John R. Adair, The Bioprospecting Question: Should the United States Charge Biotechnology Companies for the Commercial Use of Public Wild Genetic Resources? 24 Ecology L.Q. 131 (1997).

${ }^{243}$ See TEN KATE \& LAIRD, supra note 80 , at 6. 
products, the voices of U.S. biotechnology companies, European consumers, and environmentalists are heard, but those of farmers and consumers in developing states are not.

These examples are not meant to suggest that isolated social interactions of private actors are generating clear rules of international law. They are meant to suggest, however, that in the absence of clear rules of international law emanating from relevant treaty regimes, private actors are left interpreting and clarifying those rules on their own and, in a sense, implementing them. Indeed, while treaty regimes developed by states to serve their long-term interests provide a backdrop for regulation of transnational biotechnology, many of the concerns discussed in Part III ultimately are being handled through private or quasi-private contractual arrangements among non-state actors. As discussed in Part IV, international law could be strengthened by finding ways of better coordinating both state and non-state actors social interactions, as well as allowing those interactions to help inform the decisions of states, including the crafting and amending of treaty commitments.

\section{International Law as Grounded in National Law and Society}

While states and other actors may be motivated by advancing their self-interests, and may define and redefine those interests as entities embedded in the transnational system, some scholars see international law as only fully crystalized when it becomes part of the internal normative system of the state. This section will consider such "internalization" as a component of the jurisgenerative nature of international law.

For Harold Koh, the transnational legal process is one in which "an international law rule is 
interpreted through the interaction of transnational actors in a variety of law-declaring fora, then internalized into a nation's domestic legal system."244 Under Koh's theory, a norm might be internalized through social, political, or legal processes by means of various potential mechanisms: transnational norm entrepreneurs, such as non-governmental organizations or individuals; governmental norm sponsors; transnational issue networks or "epistemic communities" consisting essentially of networks of professionals with expertise in a particular domain; interpretive communities and law declaring fora; bureaucrats charged with ensuring that national law comports with international obligations; and issue linkages, whereby failure to internalize a norm can have adverse cascading effects on other matters of concern to a state. ${ }^{245}$ Philip Trimble carries the notion of internalization to the point of saying that there is no single, unitary system of international law applicable across the world community, but only "a series of parallel systems, more or less convergent depending on the subject, separately applicable within the various nations of the world."246 Treaties and customary international law standing alone may or may not have significance depending on the constitutional structures of those systems. ${ }^{247}$

${ }^{244}$ See Koh, Bringing International Law Home, supra note 191, at 626.

${ }^{245}$ Id. at 646-655; see also Anne-Marie Slaughter, The Real New World Order, FOREIGN AFF., Sept.-Oct. 1997, at 183.

${ }^{246}$ See Phillip R. Trimble, International Law, World Order and Critical Legal Studies, 42 StAN. L. REV. 811, 835 (1990).

${ }^{247}$ On customary international law in the U.S. law, compare Curtis A. Bradley \& Jack L. Goldsmith, Customary International Law as Federal Common Law: A Critique of the Modern Position, 110 Harv. L. Rev. 815 (1997), with Harold Hongju Koh, Is International Law Really State Law?, 111 HARV. L. REV. 1824 (1998). On treaties in U.S. law, see John C. Yoo, Globalism and the Constitution: Treaties, Non-Self-Execution, and the Original Understanding, 99 Colum . L. REV. 1955 (1999) and the subsequent responses. 
Examples of such internalization of international law in national law abound in the field of biotechnology. In the wake concluding the Biodiversity Convention, most developed states and many developing states moved to develop national laws and regulations, or to modify existing laws and regulations, to address access to genetic resources and the safe development and commercialization of genetically modified products. ${ }^{248}$ To do so, many developed states are using procedures recommended by the WHO or the OECD, ${ }^{249}$ and are being helped by international institutions such as the World Bank and the Biodiversity Convention secretariat, as well as non-governmental organizations. A common approach in developed states for creating such a system is through the use of a national technical advisory committee, charged both with coordinating various regulatory ministries, as well as developing and applying appropriate guidelines, such as Australia's Genetic Manipulation Advisory

${ }^{248}$ See Commission on Sustainable Development, Report of the Secretary-General, Overall Progress Achieved Since the United Nations conference on Environment and Development, Addendum on Environmentally Sound Management of Biotechnology, para. 6, U.N. Doc. E/CN.17/1997/2/Add.15 (1997); see also David W. Altman, Issues and Problems in the Transfer of Biotechnology, in Plant Biotechnology Transfer to Developing Countries, supra note 30 , at 21, 29.

${ }^{249}$ Most OECD states have adopted the OECD guidelines on safety of biotechnology, either into their existing regulatory framework or through passage of specially-designed laws. See Anne Kathrine Hvoslef-Eide \& Odd Arne Rognli, Environmental Issues for Plant Biotechnology Transfer: A Norwegian Perspective, in Plant Biotechnology Transfer to Developing COUNTRIES, supra note 30, at 37,42. The essence of the guidelines is to encourage states to follow a principle of information exchange, to develop national regulation in a manner that does not hinder the development of biotechnology, and to develop risk assessment procedures for the industrial, agricultural, and environmental applications of biotechnology. For links on the Internet to national programs of OECD (and some non-OECD) states concerning biotechnology or biosafety, see $<$ http://www.oecd.org/ehs/biolinks.htm>. 
Committee. ${ }^{250}$ Where the Convention on Biological Diversity was ambiguous or vague about issues such as access to genetic resources or the transfer of financial assistance and technology, these national laws and regulations are providing far greater content, and in the process interpreting and clarifying the Convention.

As an example of the importance of this internalization of norms, one might consider the United States position on the Convention on Biological Diversity. Although the United States has not ratified the Convention, it is nevertheless confronted by the reception of the Convention's rules into the national law of other states. In the wake of entry into force of the Convention, many states (particularly developing states that had no laws in this area) passed national laws that accomplish the Convention's essential objectives, such as laws requiring foreign researchers to sign contracts to pay "bioroyalties" on any income they derive from locally acquired plants. ${ }^{251}$ For instance, in 1995, the Government of the Phillippines issued a presidential executive order (1) requiring prior informed consent by the government, as well as local and indigenous communities, before an entity may bioprospect in the Phillippines; (2) establishing a regulatory framework for conducting bioprospecting, which calls for bioprospectors to enter into mandatory "research agreements" with the government on sharing of genetic materials, technology and benefits; and (3) creating a regulatory body to ensure implementation

${ }^{250}$ See Gaye Middleton, Australia; Gene Technology: Proposed New Regulatory Regime, 3 Bio-ScIENCE L. Rev. 104 (1999/2000). Most developing states, however, are not yet in a position to operate such committees and look to developed states for assistance.

${ }^{251}$ In addition to the Philippines, states such as Bolivia, Colombia, Costa Rica, Ecuador, Peru, and Venezuela have all adopted laws controlling access to genetic resources and requiring compensation. See Andrew Pollack, Biological Products Raise Genetic Ownership Issues, N.Y. Times, Nov. 26, 1999, at A1. For a discussion of Brazil's law, see Anthony Faiola, Amazon Cash Crop: Brazil Seeks 'Bioroyalties' from Western Drug Firms, WASH. Post, July 9, 1999, at A21. 
of these steps. ${ }^{252} \mathrm{~A}$ variant of such a law requires the foreign researcher to conduct its research with a local partner to ensure a sharing of the fruits of the research.

Further, some developing states have even considered enacting laws that would compel foreign companies present in their territory to license biotechnology applications at low rates. This possibility was anathema to developed state negotiators of the Convention on Biological Diversity, but because the issue was glossed over with ambiguous provisions, it left open the possibility of national laws compelling transfers of technology. ${ }^{253}$ While the United States has traditionally opposed such laws, ${ }^{254}$ the extraordinary value of biotechnology for alleviating hunger, disease, and suffering in the developed world may even induce shifts in U.S. law for protection of intellectual property rights for at least some biotechnology applications. For instance, on May 10, 2000, President Clinton issued an executive

${ }^{252}$ See Charles Victor Barber \& Antonio La Vina, Regulating Access to Genetic Resources: The Philippines Experience, in ACCESS to GenetiC RESOURCES, supra note 242, at 115.

${ }^{253}$ Other conventions are open to the possibility. The Paris Convention for the Protection of Industrial Property itself recognizes that party states "shall have the right to take legislative measures providing for the grant of compulsory licenses to prevent the abuses which might result from the exercise of the exclusive rights conferred by the patent, for example, failure to work." See Paris Convention, art. 5(2). Further, the TRIPS Agreement sets forth in some detail standards under which a government can authorize compulsory licensing of patented technology. See TRIPS Agreement, art. 31. Further, Article 27(2) provides that states need not extend protection to a patented invention if preventing commercial exploitation is necessary to protect human health.

254 The prospect of compulsory licensing of U.S. intellectual property to developing states has troubled U.S. companies, but it should be noted that compulsory licensing is a part of U.S. law in various contexts. For instance, under the Plant Variety Protection Act, 7 U.S.C. §2404 (1994), the government may compel a plant breeder to license a novel plant variety to others at a reasonable royalty if necessary to ensure an adequate supply of fiber, food or feed, when the owner is unwilling or unable to meet public demand at a reasonable price. Similarly, in the patent context, there are instances where the government can compel licensing to promote sustainable development. See 42 U.S.C. $\S 1857 f-1$ (1994) (compulsory licensing of clean air technology). 
order declaring that the United States would not pursue enforcement of intellectual property rights concerning patented AIDs drugs where infringements make the drugs more readily available in subSaharan Africa at lower prices. ${ }^{255}$

Yet internalization in national systems has occurred not just from the top-down, but from the bottom-up as well. European environmental and consumer groups, as well as certain individuals, looked at the relevant treaties and saw insufficient means for protecting their interests, but also lacunae that could be exploited through national laws and regulations that would protect those interests. Such nonstate actors were the engines for forcing governments, through aggressive protests and boycotts coordinated on a transnational scale, to take a much more cautious approach in regulating the development and marketing of genetically modified products. ${ }^{256}$ For instance, in the United Kingdom such protests prompted the U.K. government and life science companies to agree to a moratorium on the commercialization of genetically modified crops in the United Kingdom pending research into their

${ }^{255}$ See Exec. Order No. 13,155, 65 Fed. Reg. 30,521 (2000). The principal trade organization for the U.S. drug industry immediately responded by asserting that the executive order "sets an undesirable and inappropriate precedent by adopting a discriminatory approach to intellectual property laws, and focusing exclusively on pharmaceuticals." See Neil A. Lewis, Clinton Tries to Expedite AIDS Drugs Into Africa, N.Y. TIMES, May 11, 2000, at A7. On the following day (May 11), however, several pharmaceutical companies announced a willingness to cooperate with the Joint U.N. Programme on HIV/AIDS (UNAIDS) to find ways for broadening access to care and treatment of HIV/AIDS, including affordable and effective use of drugs for HIV/AIDS-related illnesses. See UNAIDS Press Release on New Public/Private Sector Effort Initiated to Accelerate Access to HIV/AIDS Care and Treatment in Developing Countries (May 11, 2000), $<$ http://www.unaids.org/whatsnew/press/eng/geneva1110500.html .

${ }^{256}$ See Matthew Stilwell \& Brennan Van Dyke, An Activist's Handbook on Genetically Modified Organisms and the WTO (Center for International Environmental Law, March 1999); see generally Warren Hoge, Britons Skirmish Over Genetically Modified Crops, N.Y. Times, Aug. 23, 1999, at A3; T.R. Reid, Altered Crops on Trial in Britain, WASH. Post, Apr. 16, 2000, at A31. 
environmental effects. ${ }^{257}$ "Networks of experts" joined in the debate, such as the British Medical Association, which issued a report stating that all genetically modified foods should be labeled as such, and processed separately from conventional crops, although stopping short of finding that such foods were dangerous. ${ }^{258}$ Ultimately, the U.K. government ordered restaurants, cafes, delicatessens, fastfood outlets, and caterers to inform customers if their meals contained genetically modified products. ${ }^{259}$ By contrast, Swiss voters have twice rejected by large margins referenda calling for a ban on all genetic research and for a ten-year moratorium on field trials or sales of genetically modified organisms. ${ }^{260}$

The U.S. Government has not been immune to public agitation, as may be seen in recent changes undertaken by the three principal agencies responsible for regulating biotechnology applications. In the early 1990's, when first faced with how to regulate genetically modified foods, the FDA decided that they could be regulated in the same way as conventional food varieties. ${ }^{261}$ Thus, the FDA did not itself undertake testing of biotechnology food products, nor require consultation from

${ }^{257}$ See Ehsan Masood, UK Holds Up Applications of Genetically Modified Crops, 395 NATURE 830 (1998).

${ }^{258}$ See Rick Weiss, British Report: Label Gene-Modified Food, WASH. Post, May 18, 1999, at A2.

259 See National Reports: United Kingdom, BIO-SCIENCE L. REV. 10, 110-11 (1999/2000) (describing the U.K. food labeling regulations which came into force in September 1999).

${ }^{260}$ See Donald G. McNeil Jr., Protests on New Genes and Seeds Grow More Passionate in Europe, N.Y. TIMES, Mar. 14, 2000, at A1.

${ }^{261}$ Internal documents released by the FDA in response to a lawsuit by a non-government group, the Alliance for Bio-Integrity, see infra note 264, show that there were conflicting views within the FDA as to whether this approach was appropriate. See Marian Burros, Documents Show Officials Disagreed on Altered Food, N.Y. Times, Dec. 1, 1999, at A15. 
companies intending to market genetically modified food or food ingredients. Yet the strong reaction among European consumers that genetically modified foods were not adequately regulated, which in turn led both to threatened trade restrictions and to increased concerns among U.S. consumers, prompted the U.S. biotechnology industry by the late 1990s to seek greater regulation by the FDA. Consequently, beginning in May 2000, the FDA altered its policy so as to require consultation from companies intending to market genetically modified food products. ${ }^{262}$ In essence, U.S. manufacturers saw greater government regulation as a means of assuaging consumer concerns. At the present time, additional pressures remain. Several U.S. consumer organizations are lobbying for changes in U.S. law to require labeling of foods to reflect their genetic origin, particularly since absent labeling, consumers cannot evaluate personal risks in eating a product. ${ }^{263}$ Consumer groups such as the Center for Food Advocacy and the Alliance for Bio-Integrity have even sued the FDA to force it to reclassify genetic

262 Prior to May 2000, most companies voluntarily consulted with the FDA to avoid unexpected FDA regulation after marketing had occurred. These consultations simply involved assurances from the company of origin that the food was safe, which critics charged was often based on inadequate and self-serving studies. In May 2000, the FDA announced that it would change its policy so as to require such consultations. See FDA Press Release on FDA to Strengthen Pre-Market Review of Bioengineered Foods (May 3, 2000), $<\mathrm{http} / / / \mathrm{www} . f d a . g o v /$ bbs/topics/news/new00726.html>; see also White House Press Release on Clinton Administration Agencies Announce Food and Agricultural Biotechnology Initiatives: Strengthening Science-based Regulation and Consumer Access to Information (May 3, 2000), $<$ http://www.pub.whitehouse.gov/uri-res/I2R?urn:pdi://oma.eop.gov.us/2000/5/4/10.text.1>.

${ }^{263}$ Special labeling is only required when a food's nutritive value is significantly altered or when consumers need to be informed about a safety issue. Although "additives" to foods must be disclosed to consumers through labeling, genetic information added to food generally is not regarded by the FDA as a food additive since it does not significantly alter the structure, function, or amount of substances otherwise found in the food. 
modification as an additive that would require labeling. ${ }^{264}$

Within the USDA, the Animal and Plant Health Inspection Service (APHIS) is charged with regulating the introduction of genetically modified products into the environment and food system. ${ }^{265}$ When initially faced with biotechnology applications, APHIS decided simply to review data supplied by the producer to determine whether the new plant exhibited pathogenic properties, was more likely to become a weed than its non-modified parent, was likely to increase the weediness potential of other plants with which it might interbreed, could cause damage to processed agricultural commodities, or was likely to harm other organisms (e.g., insects or worms) that are beneficial to agriculture. ${ }^{266}$ However, the transnational backlash of complaints principally by environmental organizations about the lack of testing for long-term effects ultimately led to a proposal by the USDA in July 1999 to establish

${ }^{264}$ See, e.g., Alliance for Bio-Integrity v. Shalala, No. 1:98CV01300 (D.D.C. filed May 27, 1998). The suit by the Alliance cites for support both the First Amendment's protection of religious freedom and the Religious Freedom Restoration Act of 1993, 42 U.S.C. §2000bb (1994), which requires that federal laws and regulations not impede the free exercise of religion.

${ }^{265}$ USDA regulations provide for a petition process to determine whether a product is regulated at all. If found not to be regulated, the product requires no APHIS review before its release into the environment.

${ }^{266}$ APHIS requires producers to notify or to obtain permits for field tests of genetically modified organisms considered potential risks, which may proceed if APHIS issues a "determination of non-regulated status." See 7 C.F.R. $\$ 340$ (a) note 1 (2000). APHIS then monitors the thousands of field releases of genetically engineered plants that have occurred to date in the United States, although critics have charged that the data collected are too sketchy and incomplete to be useful in assessment of ecological risks. See, e.g., Snow \& Palma, supra note 46, at 94. The USDA has set up a National Biological Impact Assessment Program to collect, store and retrieve data on field tests, thereby allowing it to develop risk assessments. 
regional centers throughout the United States to evaluate biotech products over a long period of time. ${ }^{267}$

The EPA requires that it be notified of all field testing, which cannot proceed unless EPA determines that the field test will not cause an "unreasonable adverse effect" on the environment and issues an experimental use permit. Based on the experiment's results, EPA may then register the product for commercial sale. The EPA, however, considers most foods, such as the genetically modified potato, as safe for the environment because the two genetic organisms (the potato and the natural soil bacterium Bt) are safe in their normal conditions, and therefore are presumed safe when genetically combined. Like the FDA and USDA, however, EPA has reacted to concerns by non-state actors regarding genetically modified products. For instance, in the wake of complaints by environmentalists about harm to monarch butterflies and other ecological risks, EPA placed restrictions in early 2000 on the cultivation of genetically modified corn, requiring that farmers plant 20 to 50 percent of their acreage in conventional corn. ${ }^{268}$

The jurisgenerative structure of international law is such that-despite the fragmentation of international law in this area-a transnational biotechnology regime is emerging based on the selfinterest of states and non-state actors, on the social interaction among those actors through international institutions and non-governmental organizations, and on the national law, regulations, and policies that

${ }^{267}$ See Marian Burros, U.S. Plans Long-Term Studies on Safety of Genetically Altered Foods, N.Y. Times, July 14, 1999, at A16; Secretary of Agriculture Dan Glickman, New Crops, New Century, New Challenges: How Will Scientists, Farmers, And Consumers Learn to Love Biotechnology and What Happens If They Don't?, Remarks before the National Press Club, 3-4 (July 13, 1999), <http://www.usda.gov/news/releases>.

${ }^{268}$ See Rick Weiss, EPA Restricts Gene-Altered Corn in Response to Concerns, WASH. Post, Jan. 16, 2000, at A2. 
clarify, interpret and implement international law. The United States cannot simply opt out of this regime by failing to join key treaties; international law reverberates so as to affect the United States and even alter U.S. laws and regulations. Yet, as discussed next, to address sensibly the myriad transnational concerns that have arisen and will arise in this area, the United States and the global community as a whole need to move away from reliance principally on government-negotiated, sector-specific treaty regimes as a means of managing transnational biotechnology, and to consider ways of fostering more elaborate and repeated cooperation and bargaining among the most relevant non-state actors.

\section{TOWARD AN EPISTEMIC COMMUNITY}

Part III clarified and analyzed six specific concerns about biotechnology in the transnational sphere and associated international law and structures. There is no single treaty regime addressing these concerns but, rather, a segmented and at times conflicting network of intellectual property, trade, and environment treaties, accompanied by ambiguous customary law or principles. Part IV emphasized that international law develops and regulates transnational behavior in a manner that goes well beyond the development treaty regimes; while the self-interest of states remains at the core of the transnational legal process, the social interaction of states and non-state actors is a key element, as is the need to ground transnational rules in national laws and society. Thus, while Part III emphasized the need for coordination across different treaty regimes, Part IV emphasized the need for coordination at different levels of state and non-state behavior as the law develops over time. This section argues that the principal emphasis of the global community on episodic and segmented intergovernmental negotiations 
as a means for addressing these concerns is misplaced, especially since the science in this area is changing rapidly, the behavior to be regulated is highly commercial and private in nature, and transnational regulation affects a wide variety of state and non-state actors who have complex motivations that change over time. Rather, the transnational community should develop a means for coordinating behavior across sectoral regimes and across transnational legal processes.

\section{Developing an Epistemic Community}

Studies of well-functioning international regimes suggest that regimes are, at the outset, relatively informal and non-binding, yet "rooted in a normative community generating common standards of legitimation." ${ }^{269}$ Consequently, when pursuing an effective, binding international regime, there is value in first fostering a relatively informal, non-binding regime as a means of creating shared understandings among knowledgeable actors about the substance and process of the desired binding regime. These shared understandings aid in shaping processes of authoritative decision, establishing the language by which the relevant actors will engage in discourse, establishing what kinds of discourse are relevant to the discussion, and determining whose interests are truly at stake such that they may participate in the discussion. This informal, non-binding regime may be characterized as an "epistemic community"270

${ }^{269}$ See Jutta Brunnée and Stephen J. Toope, Environmental Security and Freshwater Resources: Ecosystem Regime Building, 91 AM. J. InT'L L. 26, 31-32 (1997) (referring to such informal, non-binding regimes as "contextual").

${ }^{270}$ See generally Colloquy, Knowledge, Power, and International Policy Coordination, 46 INT'L ORG. 1 (1992). While an epistemic community is often thought of as a group of scientists or technical groups, it is used here in a broader sense of experts and policy-makers from different fields 
and, if successful, would operate in a manner that depoliticizes the identification of problems and priorities because it has no inherent power to impose its views on anyone. Yet, once these shared understandings crystalize, the time is ripe for development of a more binding regime that will be perceived as legitimate by the relevant actors, and thus can be an effective regime. Absent this shared understanding, a purportedly "binding" regime that does develop will likely be either highly general in nature and full of ambiguity, or will be unacceptable to one or more of the relevant actors, or both. In any event, it will likely not be effective.

The current regimes relevant to biotechnology are limited in their effectiveness in large part because of the absence of an epistemic community of relevant actors. At one time, the GATT represented a fairly effective regime because it was driven by certain shared understandings among principally Western states and non-governmental actors interested in economic and trade matters. The conclusion of the Uruguay round brought an increasing number of states into the GATT and brought significant reform to the GATT dispute resolution system under new WTO procedures. Yet this broader membership of the WTO and its greater capacity to unsettle national decisions has simultaneously led to a fracturing of earlier shared understandings. Increasingly, developing states demand that their interests be addressed and non-governmental actors previously uninterested in trade matters - such as labor, consumer, human rights, and environmental groups - have emerged seeking a voice in WTO decisions. These groups distrust WTO rules and the WTO process, charging that it is secretive and insensitive to the adverse environmental affects of trade, and their attitudes affect the

capable of discussing intelligently the issue of biotechnology from a variety of perspectives: economic, environmental, ethical, and so on. 
functioning of WTO rules. The Beef Hormones case is an example of this influence; while the United States won the case, the EU has refused to abide by the decision and instead regards the loss of free trade as a preferred outcome. As occurred at the Seattle summit, it appears likely that any future trade talks will be highly controversial and, if they follow their traditional approach, will have difficulty taking account of claims by non-governmental actors. Absent a change in the regime, similar results are likely in the upcoming era of transnational biotechnology.

The regime of the Biodiversity Convention is also an example of limited effectiveness. Although it has been ratified by an extraordinary number of states in a short period of time, the provisions contained within the Convention are extraordinarily broad, vague, and full of ambiguity; a result not just of difficult disputes among states over core issues surrounding sustainable development, but also of the speed with which the Convention was negotiated, which provided no time for the development of shared understandings among states, let alone among private actors, that might have generated a more sophisticated legal regime. The Convention is helpful in creating a standing Secretariat that can assist developing states in establishing laws to help preserve biological diversity, but the Convention does not direct states toward any specific policy approaches. With respect to issues of biotechnology, the Convention sets down certain broad principles - states cannot deny access to their genetic resources, while at the same time they are entitled to share in the benefits that flow from those resources-but the details about how these principles should be implemented is left largely to private actors, without providing any means for those actors to overcome the difficulties of coordination and other transaction costs. Just as environmentalists are wary of the WTO, corporations are wary of the structures 
associated with the Biodiversity Convention. ${ }^{271}$

The Biosafety Protocol was negotiated over the course of five years, after several rounds of negotiation, including a "final" round that was postponed for a year in order to allow more time for positions between the "Miami group" and the rest of the participants to mature. ${ }^{272}$ As a consequence of the lengthier process, the Protocol succeeded in developing certain binding rules that are likely to be more effective, such as the advanced informed agreement procedure regarding exports of LMOs intended for release into the environment. At the same time, many genetically modified products are not covered by the Protocol and one may question whether the one-time notification-and-consent procedure will prove effective in the long-term. Thus, some static rules emerged from the highlycharged negotiations, but others were left unaddressed. Unfortunately, static, incomplete rules can have the effect of institutionalizing inequalities or of deflating further efforts at regime building that are in fact desirable.

Rather than rely principally on these piecemeal negotiations in different legal arenas (along with the occasional WTO panel decision) as a means for resolving problems in the field of transnational biotechnology, an effort should be made to develop an epistemic community concerning transnational biotechnology that spans different sectors (trade, environment, intellectual property, and so on). Such a community would permit relevant actors to interact repeatedly over extended periods of time, thereby promoting cooperative behavior and bargaining of interests, and might lead to an epistemic consensus,

${ }^{271}$ See TEN KATE \& LAIRD, supra note 80, at 296 (two-year survey of corporate opinion revealed that many companies have come to believe that the implementation of the Convention has gone badly wrong).

${ }^{272}$ See supra note 196 and accompanying text. 
one that overturns the existing knowledge of those actors by providing a persuasive and superior approach for addressing the promise and perils of biotechnology. ${ }^{273}$ Moreover, such a consensus could lead to successful development of superior legal rules and institutions. ${ }^{274}$ If a common perspective can be freely developed among the relevant actors, and if this in turn leads to convergent policies, then the subsequent legal regime will be stronger, will contain more complete and more precise rules, is more likely to promote state compliance, will attract public support, and is more likely to adapt effectively over time. ${ }^{275}$

Creation of such a community entails its own difficulties and likely would not solve all of the problems identified in Part III. The issues described there are complex ones which have no obvious solution. Yet an epistemic community of diverse interests, if properly devised, could avoid the problem of being captured (or being perceived as captured) by a single constituency, such as trade interests or environmental interests, and thus solutions it reaches should have broad appeal. Further, by having actors participating equally from different sectors, the problem of the fragmentation of different treaty regimes might be overcome, allowing greater reflection on coordinating, amending or supplementing those regimes. By having both state and non-state actors participating, the likelihood of developing solutions that can achieve the fullest and most effective implementation in international law should be

${ }^{273}$ For a discussion in the context of the global regulation of pesticides, see PETER Hough, THE Global Politics of Pesticides 158-62 (1998).

${ }^{274}$ See Oran R. Young \& Gail Osherenko, Polar Politics:Creating International ENVIRONMENTAL REGIMES 240-45 (1993).

275 See Peter M. Haas, Do Regimes Matter? Epistemic Communities and Mediterranean Pollution Control, 43 InT'L ORg. 377, 377-80 (1989); Robert O. Keohane, The Demand for International Regimes, 36 INT'L ORG. 325, 334 (1982). 
enhanced. And if the community is structured so as not itself to create binding commitments, then the focus will not be on static and incremental high stakes treaty negotiation but, rather, on an ongoing dialogue for resolving problems by cooperatively inclined actors, whose positions can be defined and redefined over time as the prospects and problems of biotechnology unfold.

\section{The Structure of a Transnational Forum}

What transnational structure is best suited to create such an epistemic community? The emergence of the potentially revolutionary science of biotechnology is not the first time that the economic potential of new technologies has clashed with other values. An interesting analogue is the emergence of the industrial revolution in Europe in the nineteenth century, during which economic opportunities, ambitions, and problems caused enormous upheavals in the structure of the largely agrarian societies and altered irreversibly a wide variety of relationships (most notably that of the laboring class to those possessing capital), as well as prompted rapid increases in economic intercourse among European states. Concomitantly, the industrial revolution allowed the development of cheap and rapid transport and communication across Europe (and ultimately the globe), which broke down barriers that previously existed for transnational cooperation among actors in different states. Thus, it is no surprise that one can chart the emergence, principally in Europe, of hundreds of transnational nongovernmental organizations with increasing frequency during the period 1815 to $1914{ }^{276}$ These

${ }^{276}$ See F.S.L. LyONS, INTERNATIONALISM IN EUROPE 1815-1914 at 14 (1963). Lyons writes: 
organizations came in many shapes and sizes, but most had the following attributes: (1) membership from different nationalities; (2) membership open to all persons desiring to join provided they fulfilled certain conditions (such as payment of a membership fee); (3) promotion of a general or world aim, and not a purely commercial motive; and (4) a permanent nature. Moreover, many of these transnational, non-governmental organizations ultimately led to the establishment of international organizations, such as the International Labour Organization, ${ }^{277}$ some of which involved representatives from not just governments, but certain non-government constituencies as well. ${ }^{278}$

$[U]$ sually what happened was that associations of private individuals pursuing similar aims in different countries began to hold international conferences and to form international associations. These entirely private bodies then became pressure-groups functioning over a wide area and, if they were important or effective enough, ended by attracting the attention of a government, or governments, which then took over the particular issue in question and made it the subject of a public international conference.

Id. at 20. This trend, of course, has continued. See Steven Weber, Institutions and Change, in New Thinking in International Relations Theory 229 (Michael W. Doyle \& G. John Ikenberry eds., 1997).

${ }^{277}$ In the wake of the industrial revolution, national labor organizations banded together by the end of the nineteenth century to form an International Association for the Protection of Labour. Governed by an international committee on which the national sections were represented, the functions of the association were to collect and publish labor laws, reports and other relevant documents, to further the study of national labor laws and consider means of harmonization, and to maintain close relations among labor reformers in various states. Because of the seriousness and credibility of its work (e.g., gathering extensive scientific evidence concerning hazards to workers), governments began sending representatives to its meetings. During the course of its twenty year life, the association served as the engine for the development of international treaties on night work for women and on phosphorus in matches, and ultimately the creation of the International Labor Organization (ILO) in 1919, which took over its duties. See Lyons, supra note 276, at 150-54.

278 Thus, in establishing the ILO, it was recognized that having only government representatives at the table for discussions and negotiations was insufficient. The ILO Governing Body and the ILO Conference, which meets for a few weeks every year, consist not just of government representatives, but representatives from labor and business groups. See Constitution for the International Labor 
Contemporary global society, of course, has numerous non-governmental organizations that are, among other things, interested in transnational biotechnology. Yet, like the contemporary international legal regimes that touch on transnational biotechnology, most of these organizations are highly fragmented and are principally focused not on close interaction with other non-governmental organizations that have differing views but, rather, on lobbying governments as part of the intergovernmental negotiating process. To the extent that these organizations meet at a global forum, the forum is typically a single meeting held in tandem with an intergovernmental meeting at which nongovernmental organizations of largely the same type are represented. ${ }^{279}$ Instead of such a model, what is needed is a sustained dialogue through an association of all the principal actors in the field of biotechnology. Such an association might be formed purely among private actors or among private actors but with assistance of governments.

In areas other than biotechnology, there are some examples of associations formed purely among diverse private actors to tackle particular transnational problems. For instance, when it became increasingly clear that unregulated market forces on a global level were leading to rapid depletion of global forest resources, and that unorganized boycotts and labeling schemes were simply confusing and

Organization, art. 3, as amended, Oct. 9, 1946, 62 Stat. 3485, 15 U.N.T.S. 35; see also C.W. Jenks, The Significance for International Law of the Tripartite Character of the International Labour Organization, 22 Transactions of THE Grotius SociETy 45 (1936); John McMahon, The International Labour Organization, in THE EvOLUTION OF INTERNATIONAL ORGANIZATIONS 177 (Evan Luard ed., 1966); THE ORIGINS OF THE INTERNATIONAL LABOR ORGANIZATION (James T. Shotwell ed., 1934). Article 3 provides that the representatives should reflect the widest range of views within their groups.

${ }^{279}$ Examples would be the non-governmental conferences held in tandem with the 1992 Rio de Janeiro U.N. Conference on Environment and Development (UNCED), the 1995 Beijing U.N. conference on population, and the 2000 Warsaw conference on democracy. 
even misinforming consumers, a diverse group of representatives from environmental and conservation groups, the timber industry, the forestry profession, indigenous peoples' organizations, and other organizations joined together in 1993 to form the Forest Stewardship Council (FSC). The FSC is an independent, non-profit, non-governmental organization headquartered in Oaxaca, Mexico, that has some 300 members from more than 50 states. The purpose of the FSC is to promote responsible forest management by encouraging the development of national and regional forest management standards, by evaluating and accrediting independent, third-party “certifiers," and by providing public education and information about certification as a tool for ensuring that the world's forests are protected for future generations. In essence, consumers buying products carrying an FSC label can be assured that their purchase comes from a forest which has been responsibly managed according to FSC principles. ${ }^{280}$ Similar non-governmental stewardship councils or other associations are being developed to address specific problems. ${ }^{281}$

${ }^{280}$ For information on the FSC, see <http://www.fscoax.org>. The FSC is funded by its accreditation fees, membership dues, royalties for use of its logo, and from charitable donations. The FSC does not prohibit or endorse any particular forestry practice. Instead, certification under the FSC requires that the overall health and integrity of the forest ecosystem be conserved and maintained. This means ensuring that the forest is regenerated, that the biological diversity of the forest is conserved, and that the natural cycles of the forest (such as nutrient recycling) are maintained, in order to protect the long-term health and productivity of the forest. These objectives can be reached through a variety of silvicultural practices.

${ }^{281}$ For instance, in 1996 the multinational conglomerate Unilever teamed up with the World Wildlife Fund to create an independent, non-profit, non-governmental body called the Marine Stewardship Council (MSC). The MSC has developed a set of principles and criteria for sustainable fishing and has launched the first certified fish products in London. As stated in a Unilever press release, the company's intention to purchase solely from certified sources by 2005 arises from three key concerns. "First, as one of the world's largest buyers of frozen fish it seeks continuing business success. Second, as a consumer focused business Unilever must respond to consumers' needs and concerns. . . . Finally, Unilever believes that its future depends on the well-being of the communities it serves around 
Perhaps one solution to the problem of export bans outlined in Part III would be to consider an FSC-type solution, where a non-governmental association is formed from groups interested in the transnational export of genetically modified products to develop mutually agreed guidelines for development and risk assessment of such products (which, unlike the Biosafety Protocol, would not be limited to living modified organisms). If such guidelines were developed and followed by exporters, environmental and consumer groups would refrain from seeking to inhibit or boycott such exports. Yet reference to the FSC example is not principally to suggest that a non-governmental association on transnational biotechnology would necessarily develop a scheme for certifying or labeling biotechnology

the world, which in turn means that Unilever must itself act in a sustainable manner.' Unilever Press Release on Important Steps Towards Certification of Fish Products (Mar. 3, 2000), $<$ www.unilever.com>.

In response to concerns about "sweatshop" conditions of factories in developing states, human rights groups, 135 educational institutions, and U.S. shoe and apparel companies, such as Nike and Levi Strauss, formed a coalition in 1996 called the Fair Labor Association (FLA). The FLA developed a code for apparel factories anywhere in the world, including rules against forced labor and child labor, and favoring freedom of association, minimum wages, and maximum working hours, and requiring a system of independent monitoring. Companies whose factories comply can sew an FLA label into their clothing.

The world leader in linking business initiatives with sustainable development is probably the World Business Council for Sustainable Development, a coalition of some 140 transnational companies formed in 1995 and based in Geneva.

For a discussion of this phenomenon, see Peter J. Spiro, New Global Potentates: Nongovernmental Organizations and the "Unregulated” Marketplace, 18 CARDOZO L. REV. 957, 958-62 (1996) ("If a voluntary code of conduct becomes an industry standard for, say, the use of "sweatshop" labor, and that standard is monitored by non-state actors who command sympathetic constituencies, then that standard might as well be the law - supranational law, to boot, because it is not applied on a territorial basis."); see also Thomas L. Friedman, Knight Is Right, N.Y. Times, June 20, 2000, at A31 ("The best way to create global governance-over issues from sweatshops to the environment - when there is no global government is to build coalitions, in which enlightened companies, consumers and social activists work together to forge their own rules and enforcement mechanisms."). 
products. Rather, it is to note that cooperation among disparate groups in a non-governmental setting is possible to resolve issues concerning trade and environment, at least where it is in the interests of the relevant non-state actors to do so. It is in this spirit that U.N. Secretary-General Kofi Annan in 1999 initiated a U.N.-sponsored forum for encouraging and promoting good corporate practices in the area of human rights, labor and the environment, known as the "Global Compact.",282

Alternatively, a quasi-private, quasi-governmental association consisting of key actors from both governments and non-governmental organizations could be developed. A recent example that takes account of the two-level structure of international business transactions is the establishment in 1998 of the Trans-Atlantic Consumer Dialogue. That group consists of representatives of consumer organizations and of governments from Europe and the United States, and was created by the U.S. and EU as a means of expanding on existing contacts among governments, regulators, and consumer groups "to address the new consumer challenges in transatlantic relations posed by globalization," an approach "representative of a much broader trend toward the emergence of a global civil society."283 The group meets to develop recommendations that are then presented to the governments for consideration. ${ }^{284}$

${ }^{282}$ For information on the Global Compact, see <www.unglobalcompact.org $>$.

${ }^{283}$ Alan Larson, U.S. Under Secretary of State for Economic, Business and Agricultural Affairs, Consumers and the Global Economy, Remarks at the Trans-Atlantic Consumer Dialogue Dinner (Feb. 10, 2000), <http://www.state/gov>.

${ }^{284}$ A further example of such an association-one that is science-oriented in nature-is the Intergovernmental Panel on Climate Change. The IPCC was highly instrumental in developing common scientific agreement that global warming was occurring, while at the same time tempering radical assertions as to what the effects of that warming will be, thereby allowing a consensus to emerge for the creation of a framework convention. See Daniel Bodansky, The United Nations Framework Convention on Climate Change: A Commentary, 18 Yale J. InT'L L. 451, 464-711993). 
The nascent transnational pressures in the field of biotechnology have already stimulated in first steps in this direction. On May 31, 2000, the United States and the EU agreed to establish a "Consultative Forum" to review and assess the benefits and risks of biotechnology and report to the December 2000 U.S.-EU Summit. This forum will include individuals from outside government with a broad range of expertise, perspective, and interests. ${ }^{285}$ In November 1999, the OECD sponsored a meeting with more than fifty representatives of scientific associations and non-governmental organizations to discuss biotechnology and consumer concerns, environmental concerns and food concerns. ${ }^{286}$ The World Intellectual Property Organization (WIPO) has convened a Working Group on Biotechnology from the private sector and governments of its Member States. The purpose of the Working Group is to identify issues related to biotechnology and intellectual property rights, which may be included in the WIPO work program beginning in the 2000-2001 biennium, as determined by its Member States. ${ }^{287}$

A logical next step might be the creation of a global forum-perhaps entitled the "Transnational Forum on Biotechnology"- which would operate across different sectors, would involve a wide variety of non-state actors who have interests at stake in transnational biotechnology, and would meet regularly

${ }^{285}$ See U.S. Dep't of State Fact Sheet on U.S.-EU Biotechnology Cooperation Agreement (May 31, 2000), <http://usinfo.state.gov/topical/global/environ/latest/00053102.htm>; U.S. EU Agree to Pursue High-Level Talks on Biotech Trade as New Group Is Set Up, 17 Int'l Trade Rep. (BNA) 886 (2000) (providing the list of U.S. and EU members).

${ }^{286}$ See OECD, OECD Consultation with Non-Governmental Organisations on Biotechnology and Other Aspects of Food Safety, OECD Doc. C(2000)86/ADD4 (May 12, 2000).

${ }^{287}$ Biotech at the World Intellectual Property Organization, $<$ http://www.wipo.int/biotech/index-eng.html> (visited July 25, 2000). 
for an indefinite period of time. The forum could be organized initially by a particular state, such as Switzerland, by inviting states to declare their willingness to send representatives to the forum. Each state could then identify an appropriate representative from a discrete set of relevant groups, such as scientific organizations, environmental organizations, biotechnology companies, trade organizations, development-oriented organizations, intellectual property organizations, academia, labor organizations, farm groups, indigenous groups, consumer organizations, and leaders in ethics and morals. Each state could select the representative based on its ability to represent their constituency and their willingness to pay a membership fee to support the forum. Thus, the U.S. government might select $\mathrm{BIO}^{288}$ to represent U.S. biotechnology companies and Environmental Defense ${ }^{289}$ to represent U.S. environmentalist groups. Representatives could be charged with informing potentially interested parties within their group from their states of forum initiatives and with ensuring a concerted view of their group is presented to the forum. While the forum could operate in plenary, perhaps chaired on a rotating basis by representatives from each of the groups, there could also be a hierarchy of technical committees and working groups at which specialists would address particular issues.

Representatives of significant global non-governmental organizations that have achieved consultative status at relevant international organizations could be represented at the forum, such as Consumers International, Earth Council, the International Chamber of Commerce, the International Confederation of Free Trade Unions, Third World Network, Women's Environment and Development

\footnotetext{
${ }^{288}$ Supra note 212.

${ }^{289}$ For information, see $<$ http://www.edf.org $>$.
} 
Organization, and the World Business Council for Sustainable Development. ${ }^{290}$ Representatives of governments and of international organizations, such as WHO, FAO, UNEP, WIPO, World Bank, and WTO, should be represented at meetings as well, either as full members or through associate member or observer status. Particular attention would be paid to promoting participation by independent bodies of scientific experts, such as the Advisory Committee on Novel Foods and Processes (ACNFP), the International Life Sciences Institute, the Food Biotechnology Council, and the U.N. International Centre for Genetic Engineering and Biotechnology (ICGEB). ${ }^{291}$

Ideally, the host state would make available headquarters facilities for the forum and the membership fees would sustain a forum secretariat. The secretariat could serve principally to organize annual or biannual multi-week conferences of the members and to transmit documentation. Regular meetings over an extended period of time would be essential, given the dramatic changes that likely will be wrought in the "biotechnology age." Benefits as well as risks may change dramatically, and regimes created today, if static, could easily be irrelevant or outright unhelpful in years to come. Careful attention should be placed on how the agenda of the forum is to be set, on the rules of order (such as how members can speak and for how long), and the other procedures to be followed for conducting its business.

${ }^{290}$ For the respective Internet sites of these organizations, see $<\mathrm{http}: / / \mathrm{www}$.consumersinternational.org>; <http://www.ecouncil.ac.cr>; <http://www.iccwbo.org>; $<$ http://www.icftu.org>; <http://www.twnside.org.sg>; <http://www.wedo.org>; $<$ http://www.wbcsd.ch>.

${ }^{291}$ See Agreement Establishing the International Centre for Genetic Engineering and Biotechnology, Sept. 13, 1983, reprinted in 22 I.L.M. 1262 (1983). For information, see <http://www.icgeb.trieste.it/>. 
To promote a full and thorough airing of concerns, two procedural devices should be seriously entertained. First, the working conditions of the representatives should be designed to promote shared understandings, rather than divergent rhetoric. To that end, consideration should be given to closing the meetings to the press, although the results of meetings could be made public and freely discussed by representatives outside the meeting room. This is difficult issue, since the idea is to promote of a useful working environment, but not a clandestine one. Second, as is standard in international negotiations, it is probably necessary that no substantive action be taken by the forum absent complete or virtual unanimity among the representatives. The advantage of this procedural device is promote participation by all interested actors in the forum and to force them to confront each others views and to seek constructive solutions where they can. An obvious disadvantage is that such a device lends itself to paralysis, particularly among such divergent groups. That risk is real, but the forum itself will have no inherent power to change international law or institutions, so any paralysis that might occur will not itself stymie efforts to grapple with transnational biotechnology through inter-state negotiations. Rather, the power of the forum will derive from the ability to garner a consensus among all its representatives; once that occurs, any product of the forum will have tremendous legitimacy and will serve as a norm validated by key actors of the global community in this area.

While the above is just a sketch of the structure of such a forum, there are various existing fora that can provide guidance, including fairly complex ones such as the ISO ${ }^{292}$ At the same time, one can anticipate potential objections to establishing a successful forum, which would need to be approached

${ }^{292}$ See supra note 148. 
with some care. First, for some countries, non-governmental groups within a given category (e.g., environmental) are quite diverse in their views, such that finding a single organization capable of representing the rest may be problematic. While doing so in some instances will undoubtedly be challenging, a principal point of the effort (as discussion in the next sub-section) is to find common ground among divergent views, which probably needs to start with the selection of representatives at the national level. Where a single representative cannot be found, consideration may be given to use of principal/alternative representatives or rotating representation.

Second, just as there are concerns about whether governments in inter-state negotiations are legitimate proxies for the people they represent (e.g., does the government of Saudi Arabia truly represent all the Saudi people?), non-governmental organizations themselves typically operate with minimal regulation or accountability, raising questions about whose interests they are truly representing. ${ }^{293}$ Indeed, scholars applying public choice theory have noted that the aggressive pursuit by non-state actors of their own interests can result in a sub-optimal distribution of resources. ${ }^{294}$ Yet by

${ }^{293}$ See Spiro, supra note 281, at 962-63. On the notion of greater public participation in the formation of international law and standards, and some attendant difficulties, particularly in the environmental context, see Daniel Bodansky, The Legitimacy of International Governance: A Coming Challenge for International Environmental Law? 93 Am. J. INT'L L. 596, 617-19; Jonas Ebbesson, The Notion of Public Participation in International Environmental Law, 1997 Y.B. INT'L ENVTL. L. 51 (1998).

294 The classic work on the affect of interest groups on states is MANCUR OLSON, THE RISE and Decline of Nations: Economic Growth, Stagflation, and Social Rigidities (1982). For an argument that such groups are harming the global economy through new forms of "rent-seeking" global regulatory power, see John O. McGinnis, The Decline of the Western Nation State and the Rise of the Regime of International Federalism, 18 CARDOZO L. REV. 903 (1996); see also Paul B. Stephan, Accountability and International Lawmaking: Rules, Rents and Legitimacy, 17 Nw . J. INT'L L. \& Bus. 681 (1996-97). 
structuring this transnational biotechnology forum so as to encompass non-state actors from a range of sectors, such problems might be blunted, if not avoided. Broad participation in the regime process by all affected actors should reduce the concentrations of power within any particular non-state actor, and may result in a non-state consensus that reflects the equilibrium outcome among the competing nonstate actors. Further, radical positions unsupported by other non-state actors would be exposed as such, thereby diminishing the weight of such arguments.

Third, will relevant transnational actors see their interests as harmed by operating within the scope of such a forum, such that they would prefer to continue their current activities, whether it be lobbying governments and international organizations, pursuing advertising or protest campaigns to enlist public support, or simply seeking to obfuscate or undermine development of the law in the area? Several responses to this objection are possible. Some relevant actors probably will opt not to participate in the forum, yet most credible actors should see it as a means for a constructive exchange. Certainly, participation in the forum does not preclude relevant actors from undertaking any of their current activities; rather, it is a means for seeking to influence other relevant actors of their views. At the end of the day, a conclusive answer to the objection probably cannot be made unless an effort is made to establish the forum. Yet there are reasons to believe that the time is ripe for the establishment of such a forum.

A salient factor for the United States is that maintaining the status quo is not feasible. At a minimum, the United States is under increasing pressure to manage its genetic resources according to internationally agreed upon rules or risk losing foreign markets for an important segment of its goods 
and services. ${ }^{295}$ Although the United States is currently the largest producer of genetically modified products for export, in the future there also may be significant imports to the United States of genetically modified products produced abroad. Presumably it is in the United States' interest to ensure that the protections regarded as necessary for development of genetically modified products in the United States are observed abroad as well, otherwise there could be repercussions in the United States through exposure to toxins, allergens, or other adverse elements. ${ }^{296}$ As the current and likely future leader in the development of biotechnology, the United States has a special role to play in framing the goals of regulating biotechnology in the transnational sphere and in designing the means for achieving those goals.

By the same token, it would appear that the other relevant actors concerned with biotechnology in the transnational arena have incentives to cooperate and coordinate in structuring a sensible regime that addresses their concerns. Biotechnology firms wish to continue pursuing biotechnology development and application, including their ability to obtain genetic resources from developing states and to market biotechnology goods and services transnationally. They fear outright bans and disguised

\footnotetext{
${ }^{295}$ For a series of essays on how national policies are increasingly answerable to international environmental standards, see The Greening of Sovereignty in World Politics (Karen T. Litfin ed., Global Envtl. Accord Ser., 1998).

${ }^{296}$ See Exec. Order No. 13,112 (Feb. 3, 1999), 64 Fed. Reg. 6,183 (Feb. 3, 1999) (invoking legal authorities to prevent the introduction of invasive species in the United States). A general problem of stringent regulation of biotechnology in one country is that a multinational corporation might simply move its operations to another country. See Thomas O. McGarity, International Regulation of Deliberate Release Biotechnologies, 26 TEX. InT'L L.J.423, 435-37 (1991). At the same time, corporations may be inhibited from doing so by economic factors, such as the unavailability of highly skilled personnel and equipment and the difficulty of exporting products to the highly regulated market. Further, the highly regulated country may be able to engage in extraterritorial regulation if regards the foreign biotechnology process as having effects on it.
} 
bans on their products, and will find unsatisfactory the case-by-case adjudication available at the WTO, even if the end-result is favorable in striking down a particular ban. For purposes of capital investment, biotechnology companies should welcome the ability to define (and thereby encourage acceptance of) their future rights and obligations, and to be regarded as a good "corporate citizens. ${ }^{297}$ Environmental groups wish to address the uncertainty in the release of genetically modified products into the environment, and fear that either minimal or no restraints will be imposed on biotechnology firms, or that the restraints imposed will prove unenforceable. They will not wish to rely on the WTO to sort out whether a ban on biotechnology products is permissible. Governments may be torn between conflicting views, responding both to the need for economic development, equitable demands, and consumer preferences. Consumer preferences, in turn, will differ. European attitudes of late have hardened against genetically modified products; U.S. attitudes may be headed that direction. Yet consumers in developing states may strongly favor such products as a means of combating poverty and sickness. In any event, consumers will wish to see some level of regulation of biotechnology so as to address transnational concerns. Most actors should see formal coordinated action as preferable to unilateral action. $^{298}$

${ }^{297}$ For a discussion of corporate initiatives toward self-regulation in this area, see Thomas P. Redick et al., Private Legal Mechanisms for Regulating the Risks of Genetically Modified Organisms: An Alternative Pathway Within the Biosafety Protocol, 4 ENVTL. La w . 1, 57-59 (1997).

${ }^{298}$ See, e.g., John J. Sweeney, Editorial, Remember Seattle, WASH. Post, Jan. 30, 2000, at B7 (AFL-CIO President, in wake of the failed Seattle trade summit, asserting that it in the selfinterest of global corporations, banks, labor organizations, governments, and others to pursue new global rules developed democratically). 


\section{The Goals of a Transnational Forum}

In considering the goals of a transnational forum on biotechnology, there will need to be some ground rules upon which relevant actors will operate in seeking convergence as an epistemic community. Brunnée and Toope set forth a series of factors as appropriate for "ecosystem-oriented regime building" in the area of freshwater resources, which may be adapted when considering regime building in the area of transnational biotechnology. ${ }^{299}$ The community must seek to take account of the interests of all actors affected by the transnational regulation of biotechnology. The community must emphasize the common interests of all actors in protecting and preserving their interests, rather than their competing interests. In particular, the community must pursue only the elaboration of possible rights and obligations addressing the common interests of the actors, and must not seek to promote the rights of one set of actors to the detriment of another. The community must work from core principles favoring sustainable development, fairness, justice, and transparency among the actors. The community must seek to elaborate specific rules on individual issues, but must be sufficiently flexible so as to accommodate new concerns and interests as they emerge. Finally, the community must be open to crystallization of an ultimate legal regime in any number of different forms: as a new international institution or treaty; as a transformation of an existing international institutions or treaty; as a coordinated transformation of a series of existing international institutions or treaties; or as a harmonization of national laws.

${ }^{299}$ See Brunnée \& Toope, supra note 269, at 41-42, 65-75. 
The overall goal for the forum should be to help ensure that biotechnology is developed and applied only in a manner that is safe and beneficial, an objective that should be acceptable to all potential members. From this, several sub-goals may be pursued. First, at a minimum, the forum could provide an opportunity for the various relevant actors to discuss, debate, and exchange information about their respective concerns. This could be done in plenary sessions, but probably more effectively in subgroups or on the margins of meetings. One desirable outcome of such exchanges might be the reduction of general verbal formulations that appear in treaties and in judicial decisions ${ }^{300}$ ("sustainable development," "precautionary principle," "equitable sharing," etc.) to much more concrete meanings in the context of the development of biotechnology.

Second, the relevant actors might find ground for "bargaining" their positions toward an optimal, consensus-driven outcome on a wide range of issues. Though hard to articulate the complexities of such bargaining, the idea would be to allow biotechnology companies, environmental groups, indigenous groups, and others to see how their existing disagreements might turn into consensus by trade-offs or "side payments" among the different groups. Part III noted how different groups have different interests that are currently regulated in disparate treaty regimes. If these groups were brought together at a forum that allowed continuous interactions among them, perhaps they might find that environmental groups could support certain trade in biotechnology products in exchange for biotechnology companies contributing funds to environmental impact studies in importing states;

${ }^{300}$ See, e.g., Case Concerning the Gab囚íkovo-Nagymaros Project (Hung. v. Slovk.), 1997 I.C.J. 7 (Sept. 25), reprinted in 37 I.L.M. 162 (1998) (recognizing the concept of "sustainable development" as essentially a verbal reconciliation of concepts that point in the opposite direction). 
biotechnology companies might support funding for environmental impact studies as well as donations of technology in exchange for strong intellectual property protections within developing states; ${ }^{301}$ developing states might support strong intellectual property protections if their indigenous populations receive greater benefits from use of their biological heritage; in order to achieve these benefits, indigenous groups might encourage environmental groups to be less "ban-oriented." Presently these kinds of linkages crudely occur through intergovernmental negotiation of treaties, but the negotiations are so compartmentalized into the sector of any given treaty (environmental, trade, intellectual property, and so on.) and are so government-driven that it is difficult for bargaining to occur across sectoral lines and among all relevant actors.

Third, if sufficient common understanding (and trust) emerges within the forum, the forum could try to develop an integrated view on many of the activities now undertaken and duplicated across a variety of international institutions. For instance, the forum might try to develop a common position on guidelines for the assessment and management of biosafety risk factors, to assist international organizations, states, and themselves. Those guidelines would address, inter alia, physical and biological control procedures appropriate to the level of assessed risk involved in relevant research, development and application activities. There are already several guidelines that have been developed by different organizations based on their own particular interests, ${ }^{302}$ such as the OECD Group of

301 See OECD REPORT, supra note 36, at 9 ("The measures required to induce the private sector to transfer technology will include the creation of conditions in the recipient state that encourage voluntary technology transfer from abroad.”).

${ }^{302}$ For a list of international instruments relating to genetically modified products, see Background Document on Existing International Agreements Related to Biosafety, Open-Ended Ad Hoc Working Group on Biosafety, UNEP Doc. UNEP/CBD/BSWG/2/3 (1997), 
National Experts on Safety in Biotechnology, ${ }^{303}$ the UNIDO Biosafety Information Network and Advisory Service (BINAS), ${ }^{304}$ the UNEP, ${ }^{305}$ and the World Bank, ${ }^{306}$ as well as by states. ${ }^{307}$ A sensible integration of these guidelines developed by consensus of all relevant actors would provide a feasible and flexible basis for assessing biosafety.

Other goals of the forum might include developing guidelines for innovative genetic manipulation techniques; identifying and keeping under review classes of work that have undefined risk levels; alerting national authorities to the existence of novel risk factors; providing specialist technical advice on specific biosafety matters to international organizations, such as the WTO, and relevant state regulatory

$<$ http://www.biodiv.org/biosafe/pdf/bswg2-3.pdf>. Little integration exists among these instruments.

303 See OECD, SAFETy CONSIDERATIONS For BioteChNOLOGy (1992); OECD, ReCOMBINANT DNA SAFETy CONSIDERATIONS - SAFETy CONSIDERATIONS FOR INDUSTRIAL, Agricultural and ENVIRONMEntal Applications of ORganisms DeRIVEd By Recombinant DNA TECHNIQUES (1986); see generally Seizo Sumida, OECD's Biosafety Work on "Large-Scale" Releases of Transgenic Plants, 45 FIELD CROPS RES. 187 (1996). On the importance of the OECD to the formation of an epistemic community, see John BRAITHWAITE \& PETER DRAHOs, GLOBAL Business Regulation 486 (2000).

${ }^{304}$ See UNIDO, Genetically Modified Organisms: A Guide to Biosafety (1995), $<$ www .unido.org/doc>.

305 See UNEP International TechnicAl Guidelines FOR SAFETy In Biotechnology, CAIRO (1995), <http://www.unep.org/unep/program/natres/biodiv/irb/docs01.htm> These guidelines were initially drafted by the Departments of the Environment of the Netherlands and the United Kingdom. They are recognized as an interim mechanism to assist states pending the entry into force of the Biosafety Protocol.

306 See The World Bank, Environmentally Sustainable Development Studies And Monograph Series No. 10, Enabling the Safe Use of Biotechnology (John J. Doyle \& Gabrielle J. Persley eds., 1996).

307 See, e.g., Guidelines for Research Involving Recombinant DNA Molecules, 59 Fed. Reg. 34, 496 (1994). 
authorities; and establishing contact and maintaining a liaison with state regulatory authorities to ensure that, as far as practicable, national guidelines and regulations are in harmony with international practice. To assist in such tasks, agreement might be reached to establish a scientific and technical advisory group, along the lines of the scientific groups associated with the Biological Diversity Convention or the Antarctic treaty regime. Such a group would have to draw upon expertise from a variety of scientific backgrounds, including molecular biology, genetics, cell biology, evolutionary biology, physiology, population and community ecology, and ecosystem science. At a very advanced stage, this body could even be called upon to evaluate the potential ecological consequences of the planned introduction of genetically modified products into the environment of a proposed state of import, an evaluation that might include several issues: the survival and reproduction of the introduced organism; interactions with other organisms in the environment; and the effects of the introduced organism on the ecosystem function. In such instances, careful attention would need to be placed on protecting confidential business information.

While addressing issues concerning the risks of biotechnology, the forum could in tandem foster better understanding regarding the economic, political, and moral value of the sharing of its benefits. In this regard, participation at the forum of representatives from various national programs committed to promotion of biotechnology for developed states would be important. Examples of national programs to that effect are the Special Programme for Biotechnology and Development Cooperation of the Netherlands ${ }^{308}$ and the programs of the Japan International Research Center for Agriculture Sciences

308 See Bert Visser \& Hans Wessels, Plant Biotechnology for Small-Scale Agriculture, in Plant Biotechnology Transfer to Developing Countries, supra note 30, at 213. 
$(\text { JIRCAS) })^{309}$ and the U.S. Agency for International Development (AID),${ }^{310}$ which aim to increase developing states access to biotechnology and contribute to the solution of developmental problems. An example of an international program is the Intermediary Biotechnology Service (IBS), a project supported by an international group of donors, which advises national programs in developing states on matters of biotechnology research management and policy. ${ }^{311}$ As discussed previously, often private sector companies can collaborate with national or international programs to transfer technology to an institute within a developed state.

\section{Potential Crystallization of a Coherent Legal Regime}

The development of a cohesive, epistemic community on issues of transnational biotechnology would be a remarkable accomplishment. Indeed, in some instances there are sound arguments in favor of engaging all relevant parties though voluntary structures rather than trying to impose on them a

${ }^{309}$ See Keiji Kainuma, The Role of JIRCAS in International Technology Transfer Related to Biotechnology Application to Agriculture and Food Processing in Japan, in PLANT Biotechnology Transfer to Developing Countries, supra note 30, at 225.

${ }^{310}$ See John H. Dodds, Agricultural Biotechnology for Sustainable Productivity (ABSP): A U.S. Agency for International Development (USAID) Initiative, in Plant Biotechnology Transfer to DEVEloping Countries, supra note 30, at 235.

${ }^{311}$ See Joel I. Cohen \& John Komen, Research Collaboration, Management and Technology Transfer; Meeting the Needs of Developing Countries, in Plant Biotechnology Transfer to DeVEloping Countries, supra note 30, at 253. 
coercive, legislative regime. ${ }^{312}$ The speed with which technology in this area is developing argues in favor of using "soft law" instruments or using existing international organizations more effectively as a means of coordinating the behavior of relevant actors.

Yet, the success of a transnational forum might ultimately be measured by whether it leads to a binding legal regime that effectively addresses the concerns discussed in Part III. Existing international rules regarding intellectual property protection of biotechnology applications are not strong, nor are rules regarding access to or equitable sharing of the benefits from genetic resources. Through stronger rules, the beneficial aspects of biotechnology are more likely to be achieved. At the same time, while biotechnology applications generally may be safe, at least some companies in some states are likely engaged in risky commercial development of transgenic plants, ${ }^{313}$ suggesting that developing a legally binding regime on how risk should be measured, and then restricting (or at least monitoring) high-risk experiments and development would be in order.

A binding legal regime could crystalize in any number of different forms: as a new international institution or treaty; as a transformation of an existing international institution or treaty; as a coordinated transformation of a series of existing international institutions or treaties; or as a harmonization of

312 See Jonathan Baert Wiener, On the Political Economy of Global Environmental Regulation, 87 GEO. L.J. 749, 793 (1999). An example of voluntary schemes that can emerge within the non-governmental sector when relevant actors become convinced that it as in their interest to do so is the development of voluntary liability and compensation schemes in the oil pollution context. See The Tanker Owners Voluntary Agreement Concerning Liability for Oil Pollution, Jan. 7, 1969, reprinted in 8 I.L.M. 497 (1968) (TOVALOP) (amended several times); Contract Regarding an Interim Supplement to Tanker Liability for Oil Pollution, Jan. 17, 1971 (also amended several times).

${ }^{313}$ See I.M. Parker \& D. Bartsch, Recent Advances in Ecological Biosafety Research on the Risks of Transgenic Plants: A Trans-Continental Perspective, in TransGENIC Organisms: Biological AND Social ImPliCATIONS 147 (J. Tomiuk et al. eds., 1996). 
national laws. Should the global community move toward creation of a new treaty regime to regulate transnational biotechnology $?^{314}$ When the global community in the past has faced an extraordinary scientific development, capable of yielding both great benefits and great harm to the global community, establishment of a regime for transnational cooperation has been seen as a highly rational and useful policy choice. For example, the advent of nuclear power as a source of energy in the 1940's soon thereafter brought on the creation of the International Atomic Energy Commission, an organization garnering members from across the East/West, North/South divides. The IAEA became a highly effective institution in advising members regarding the safe, peaceful uses of nuclear materials, and in inspecting facilities within member states. A principal objective of the new institution would be to overcome the problem of having a multitude of international regimes all addressing pieces of the biotechnology puzzle, yet having none capable of addressing the problem as a whole. However, the likelihood (at least in the near term) of creating an entirely new institution seems low. The proliferation of international institutions in recent years has left many states with "institution fatigue," as well as "treaty congestion." ${ }^{315}$ Adding but one more institution addressing a particular area of transnational cooperation would likely be seen as a misguided effort to solve a problem by throwing more resources and energy into the creation of yet another transnational actor.

Transformation of an existing international institution or treaty might prove the most efficient means of developing binding rules. At present, however, none of the existing regimes provides an

${ }^{314}$ See, e.g., Kim, supra note 37, at 1195, 1202-04; McGarity, supra note 296, at 456-61.

315 See Edith Brown Weiss, International Environmental Law: Contemporary Issues and the Emergence of a New World Order, 81 GEO. L. J. 675, 697-702 (1993). 
especially good fit. The regime established by the Biodiversity Convention is charged with focusing principally on the conservation of biological diversity, and while that permits it to address some of these concerns, such as the balancing of access to genetic resources against transfer of benefits arising from such access, other concerns, such as food safety and trade bans against genetically modified products, are not within its purview. Moreover, even on the areas within its mandate, the provisions of the Biodiversity Convention are very general and vague in nature, and thus susceptible to multiple interpretations. The world leader in biotechnology, the United States, is not even a party to the Biodiversity Convention, let alone to the proposed Biosafety Protocol. The regime of the WTO can address the issue of trade bans, but has limited ability to assess the scientific basis of those bans. It is a reactive regime, closely scrutinizing trade restrictions (and typically striking down those purportedly based on environmental concerns), but unable to consider broader issues, such as the fairness of developed states exporting genetically modified products derived from materials of developing states. Other global regimes, embodied in the WIPO, the FAO, or the UNDP, have limited resources and a limited mandate to effect change in this area.

Perhaps the most likely development of a new legal regime would occur either through the coordinated transformation of a series of existing international institutions or treaties or through harmonization of national laws. In essence, if a "forum" succeeded in achieving common understandings or "bargains" about how to regulate transnational biotechnology, that agreement could either be grafted onto existing international agreements or incorporated directly into national laws (or both). For example, perhaps such understandings could lead to pilot projects for simultaneous regulatory approval of genetically modified products among states, whereby scientists and other regulatory officials from 
different states would do risk assessment studies simultaneously. A transparent, scientific, consensusdriven process might avoid having a genetically modified product approved in one jurisdiction but not in others. ${ }^{316}$ Such regulatory approval would likely require greater sensitivity than currently exists in national structures to the risks arising from export of genetically modified products to other regions of the world.

Bargaining within a transnational forum might ultimately lead to consensus on appropriate approaches for future development of U.S. law in this area. For instance, harmonization of legislation with other states might lead to mandating the DOC, USDA, FDA, APHIS, or the EPA (or perhaps an entirely new entity) to collect data from the producer of a genetically modified product, as well as from independent sources (such as peer reviewed journals), and to assess the data to determine that the genetically modified product presents no safety concerns from gene expression, gene flow, or toxicity or allergenic perspective with respect to proposed states of import. This would, of course, require the producer (or the exporter) to conduct field tests in the foreign state. The tests would be to determine the extent of areas the transgenic varieties will cover compared to the natural populations of the plant, whether the transgene itself will confer a selective advantage to the natural population if spread, and whether the introduced genes will be fixed in the natural populations or lost through genetic drift or natural selection. ${ }^{317}$ Where there are safety concerns with respect to a particular state, the U.S.

${ }^{316}$ In June 1999, the United States and the EU agreed to pursue such a project. See EU, U.S. Pilot Project Would Offer Simultaneous Regulatory Approval of GMOs, 22 Int'l Env. Rep. (BNA) 521 (1999).

${ }^{317}$ See Hvoslef-Eide \& Rognli, supra note 249, at 43. 
Government could bar engineered plants from being exported to that state. ${ }^{318}$

Even if bargaining within the transnational forum does not result in changes to U.S. law, such interaction would sensitize U.S. actors to the potential benefits of legal reforms and harmonization in this area, and to opportunities for assisting other states in development of their national laws and regulations. Risk assessment in the area of biotechnology has become increasingly complex, relying extensively on mathematical models, statistics, and computer modeling. The inadvertent spread of genetically modified organisms may turn on the complex interaction of repressor genes, insertional mutation, or the creation of new chromosome arrangements in existing organisms. Most developing state governments and their national industries are ill-equipped to conduct such assessments. Exploring these difficulties amidst the non-controversial setting of a transnational forum might help promote greater oversight by biotechnology exporting states. Alternatively, exporting states (or perhaps exporters themselves

318 There might be particularly high thresholds set for exports of genetically modified plants to states where the plant originated or was cultivated for centuries. Thus, it may be that genetically modified corn should be prohibited from export to Mexico or Guatemala, since those states are home to the wild grass from which corn is believed to have originated (teosinte). See JANE RISSLER \& Margaret Mellon, The Ecological Risks of Engineered Crops 117-19 (1996). For a table cross-referencing crops genetically engineered in the United States with the location globally of their wild relatives, along with an indication of the likely level of cross fertility, see J.F. Hancock et al., The Opportunity for Escape of Engineered Genes from Transgenic Crops, 31 HorTSCIENCE 1080, 1081 tbl.1 (1996).

The only exception to this prohibition might be for genetically modified products that are engineered to produce sterile off-spring. If imposing an outright ban on a state is unjust due to limited arable land and a growing population, then at a minimum, a rigorous system certifying that fields to which seeds are being sent are monitored for signs of hybridization. Some U.S. statutory authorities would already support the imposition of prohibitions. For instance, the Secretary of the Department of Health and Human Services has the discretion to disapprove export of genetically modified products when necessary to protect public health in either the United States or the importing state. See Drug Export Amendments Act of 1986, Pub. L. No. 99-660, 100 Stat. 3743, § 351(h)(1)(B)(i), codified as amended at 42 U.S.C. $§ 262(\mathrm{~h})(1)(\mathrm{B})(\mathrm{i})(1994)$. 
directly, perhaps through creation of a industry-supported fund) might provide funds for establishing and maintaining regulatory systems with developing states. A transnational forum would provide a place for pursuing such ideas without the specter of immediate incorporation in a binding international agreement.

An epistemic community of the kind called for here does not yet exist in the field of trade and environment. Were one to be created and be successful, it might serve as a template for addressing other complex problems of transnational regulation, particularly where different regimes are colliding and need reconciliation. It might even help international society free itself from some of the "obsessions and neuroses" that have led to international and internal conflict in the past. ${ }^{319}$ As the range of transnational behavior grows ever deeper, the need for stronger transnational organization grows deeper as well.

\section{CONCLUSION}

Although we are in its formative stage, the science of biotechnology may well revolutionize broad aspects of national and transnational behavior - from the food and drugs we consume, to medical treatments for disease and aging, to means of identifying who we are and what we could be. Moreover, biotechnology holds great promise for helping to eradicate hunger and disease among the poorest states of the world. Yet already a wide range of transnational concerns about transnational biotechnology

319 See Philip Allott, Eunomia:New Order for a New World 330-31 (1990). 
have emerged that severely challenge existing treaty regimes and that threaten to foreclose cooperative strategies for obtaining the widest benefits from this new science at the smallest risk. Existing regimes as well as difficulty in regulating a matter that spans areas of trade, intellectual property, environment, health, and agriculture, and difficulty in promoting desirable interactions among those entities most directly affected - non-state actors. Yet the structure of international law is such that non-state actors have become key players in the formation of treaty regimes, in the social interaction within those regimes, and in the internalization of transnational law in national law. Through formal creation of an epistemic community of knowledgeable non-state actors representing a wide range of affected interests, it is hoped that common perspectives and bargained positions can be freely developed concerning the promise and perils of biotechnology. If this epistemic community can develop convergent policies and expectations, then desirable cooperation of non-state actors may flourish, and any subsequent transnational legal regime will be stronger, will contain more complete and more precise rules, is more likely to promote state compliance, and is more likely to adapt effectively over time. 